\title{
Health and social consequences of marital violence: A synthesis of evidence from India
}

Shireen J. Jejeebhoy

Population Council

K.G. Santhya

Population Council

Rajib Acharya

Population Council

Follow this and additional works at: https://knowledgecommons.popcouncil.org/departments_sbsr-pgy

Part of the Domestic and Intimate Partner Violence Commons, Family, Life Course, and Society Commons, and the International Public Health Commons How does access to this work benefit you? Let us know!

\section{Recommended Citation}

Jejeebhoy, Shireen J., K.G. Santhya, and Rajib Acharya. 2010. "Health and social consequences of marital violence: A synthesis of evidence from India." New Delhi: Population Council. 


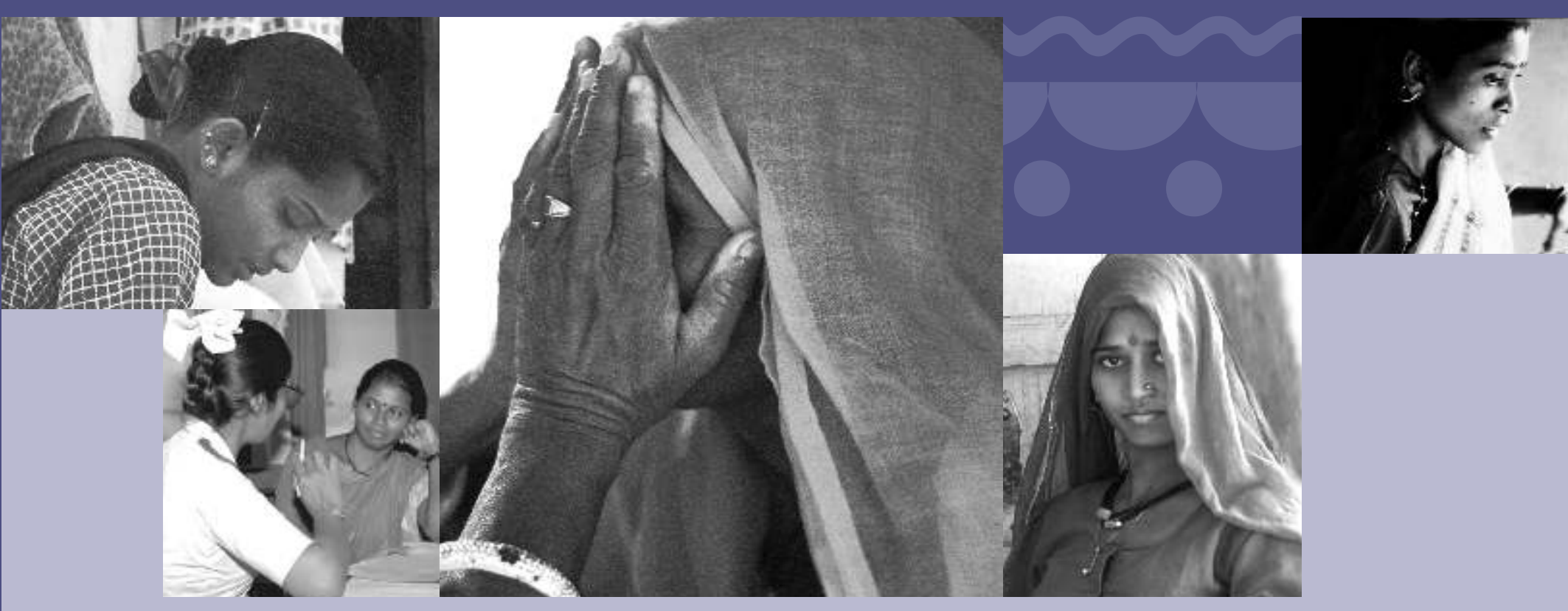

Health and social consequences of marital violence: A synthesis of evidence from India

1 Population Council

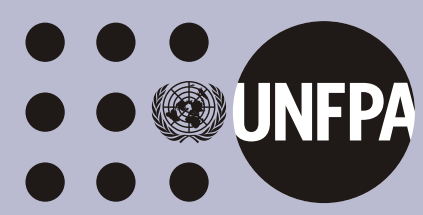


This report synthesises what is known about the health and social consequences of marital violence for women in India. It includes both a review of published and unpublished materials, and the presentation of new evidence, from further analysis of surveys of youth available to the Population Council, of these consequences for young women in India. The review focuses on sexual, reproductive and child health consequences, including contraceptive use, experience of symptoms of infection, pregnancy-related care, unintended pregnancy and abortion, foetal, perinatal and early childhood mortality; maternal and child nutrition; and mental health outcomes. It also reviews evidence of a range of social outcomes including substance use, women's autonomy and self-efficacy; and inter-generational effects (witnessing parental violence when growing up). The study was undertaken with support from the United Nations Population Fund (UNFPA), India.

For additional copies of this report, please contact:

Population Council

Zone 5-A, Ground Floor

India Habitat Centre

Lodi Road

New Delhi 110003

Phone: 011-2464 2901/02

email: info.india@popcouncil.org

Web site: http://www.popcouncil.org/asia/india.html

UNFPA, the United Nations Population Fund, is an international development agency that promotes the right of every woman, man and child to enjoy a life of health and equal opportunity. UNFPA supports countries in using population data for policies and programmes to reduce poverty and to ensure that every pregnancy is wanted, every birth is safe, every young person is free of HIV/AIDS, and every girl and woman is treated with dignity and respect.

The Population Council is an international, non-profit, non-governmental organisation that seeks to improve the wellbeing and reproductive health of current and future generations around the world and to help achieve a humane, equitable and sustainable balance between people and resources. The Council conducts biomedical, social science and public health research, and helps build research capacities in developing countries.

\section{Copyright $\subset 2010$ Population Council}

Suggested citation: Jejeebhoy, S. J., K. G. Santhya and R. Acharya. 2010. Health and social consequences of marital violence: A synthesis of evidence from India. New Delhi: Population Council and UNFPA.

The information and views expressed in this report do not necessarily reflect the views of the United Nations Population Fund or the United Nations. 


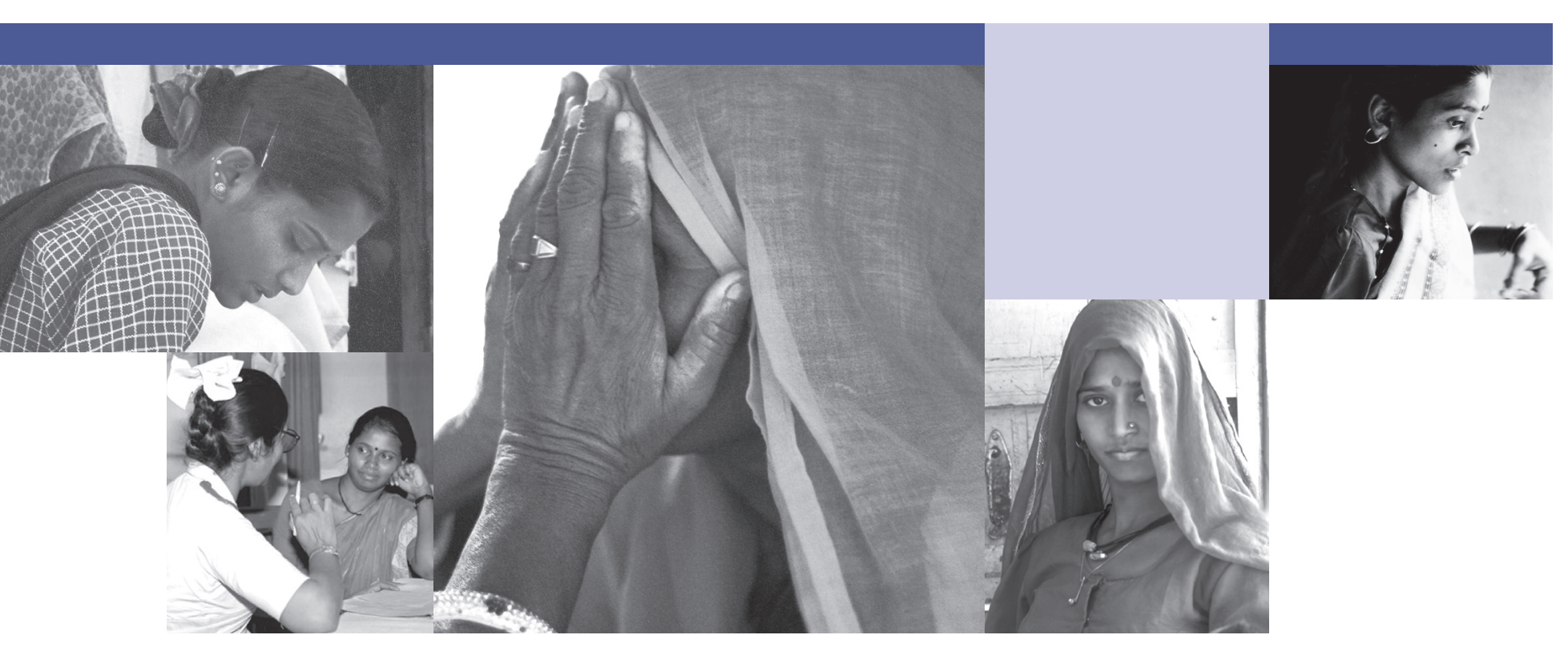

\section{Health and social consequences of marital violence: A synthesis of evidence from India}

Shireen Jejeebhoy

KG Santhya

Rajib Acharya

Population Council 



\section{Contents}

Acknowledgements

Executive summary

Chapter 1: Introduction 1

$\begin{array}{ll}\text { Introduction and objectives } & 1\end{array}$

Definitions and consequences of intimate partner violence: Framework for analysis 2

$\begin{array}{ll}\text { Methodology } & 4\end{array}$

Chapter 2: Marital violence in India: The situation 6

Chapter 3: Marital violence and sexual and reproductive health consequences 12

Modern contraceptive use 12

$\begin{array}{ll}\text { Unintended pregnancy and abortion } & 16\end{array}$

Reproductive tract infection, sexually transmitted infection and HIV 22

Pregnancy-related complications and care seeking $\quad 32$

Foetal, perinatal and early childhood mortality 36

Chapter 4: Marital violence and the nutritional status of women and children 44

Nutritional status of women $\quad 44$

Nutritional status of children $\quad 44$

Chapter 5: Marital violence and mental health consequences $\quad 50$

Chapter 6: Marital violence and social consequences $\quad 58$

$\begin{array}{ll}\text { Substance use } & 58\end{array}$

Women's autonomy $\quad 58$

$\begin{array}{ll}\text { Inter-generational effects } & 61\end{array}$

$\begin{array}{ll}\text { Economic costs } & 63\end{array}$

$\begin{array}{ll}\text { Chapter 7: Way forward } & 65\end{array}$

$\begin{array}{lc}\text { References } & 68\end{array}$ 


\section{List of tables}

Table 1.1: Health and social consequences of intimate partner violence for women

Table 2.1: Magnitude of lifetime experience (women aged 15-50) of physical and/or sexual violence within marriage: Findings from various studies, 1990s-2000s

Table 2.2: $\quad$ Magnitude of lifetime perpetration (men aged 15-65) of physical and/or sexual violence within marriage: Findings from various studies, 1990s-2000s

Table 2.3: Magnitude of lifetime experience (young women) of physical and/or sexual violence within marriage: Findings from various surveys and studies, 2000s

Table 2.4: Magnitude of lifetime perpetration (young men) of physical and/or sexual violence within marriage: Findings from various surveys and studies, 2000s

Table 3.1: Association between marital violence and contraceptive practice: Findings from various studies, 1990s-2000s

Table 3.2: Association between marital violence experienced by currently married young women and current practice of modern contraception: Findings from various surveys, 2000s

Table 3.3: Association between marital violence perpetrated by currently married young men and current practice of modern contraception: Findings from various surveys, 2000s

Table 3.4: Association between marital violence and experience of unintended pregnancy and abortion: Findings from various studies, 1990s-2000s

Table 3.5: Association between marital violence experienced by currently married young women and unwanted last pregnancy: Findings from various surveys, 2000s

Table 3.6: Association between marital violence experienced by currently married young women and experience of abortion: Findings from various surveys, 2000s

Table 3.7: Association between marital violence perpetrated by currently married young men and experience of abortion: Findings from various surveys, 2000s

Table 3.8: Association between marital violence and experience of symptoms of RTI/STI/HIV: Findings from various studies, 2000s

Table 3.9: Association between marital violence experienced by currently married young women and recent experience of symptoms of RTI/STI: Findings from various surveys, 2000s

Table 3.10: Association between marital violence and pregnancy-related complications and care seeking: Findings from various studies,1990s-2000s

Table 3.11: Association between marital violence and foetal, perinatal and early childhood mortality: Findings from various studies,1990s-2000s 
Table 3.12: Association between marital violence experienced by currently married young women and experience of any foetal mortality (stillbirth or miscarriage): Findings from various surveys, 2000 s

Table 3.13: Association between marital violence perpetrated by currently married young men and experience of any foetal mortality (stillbirth or miscarriage): Findings from various surveys, 2000 s

Table 4.1: Association between marital violence and maternal nutrition: Findings from various studies, 1990s-2000s

Table 4.2: Association between marital violence and child nutrition: Findings from various studies, 1990s-2000s

Table 5.1: Association between marital violence and mental health outcomes: Findings from various studies, 2000s

Table 5.2: Association between marital violence experienced by currently married young women and recent experience of symptoms of mental health disorders (3+ on the GHQ): Findings from the Youth In India Situation and Needs Study

Table 6.1: Association between marital violence experienced by currently married young women and recent consumption of tobacco: Findings from the Youth In India Situation and Needs Study

Table 6.2: Association between marital violence experienced by currently married young women and women's autonomy: Findings from various surveys, 2000s

Table 6.3: Association between marital violence experienced by currently married young women and witnessing parental violence when growing up: Findings from various surveys, 2000s

Table 6.4: Association between marital violence perpetrated by currently married young men and witnessing parental violence when growing up: Findings from various surveys, 2000s 


\section{List of figures}

Figure 3.1: Association between marital violence and unwanted pregnancy and abortion

Figure 3.2: Association between marital violence and experience of symptoms of RTI/STI

Figure 3.3: Association between marital violence and experience of clinically/laboratory detected RTI/STI

Figure 3.4: Association between marital violence and pregnancy-related complications and care seeking

Figure 3.5: Association between physical violence within marriage and foetal, perinatal and neonatal mortality

Figure 3.6: Association between physical violence within marriage and infant and early childhood mortality

Figure 5.1: Association between marital violence and mental health outcomes 


\section{Acknowledgements}

This review has benefitted hugely from the input of many. We are grateful to the United Nations Population Fund (UNFPA) for support, which made this study possible. We would also like to acknowledge the insightful comments and suggestions of many at UNFPA, notably Dr. Venkatesh Srinivasan and Dr. Amita Pitre, on both the design and the content of this review. We would also like to acknowledge the support of DFID for partially covering the time spent by one of the authors on this project.

We were fortunate that three eminent scholars who have worked on issues of violence against women in India-Drs. Suneela Garg, Rob Stephenson and Leela Visaria-agreed to provide external peer review comments on the report. Their comments have been incorporated in this report and are gratefully acknowledged.

We are grateful to Population Council colleagues for their support and insights as we prepared this review. Deepika Ganju provided an in-house review of the report and we are grateful to her for her inputs for reshaping the paper. M.A. Jose was responsible for conducting a search of the literature relating to our topic; his support and success in identifying many of the wide range of articles and papers included in this review is much appreciated. Komal Saxena was responsible for managing the preparation of this report; we are grateful to her for her editorial contribution and her meticulous attention to detail, which have made the report more readable and precise. 



\section{FOREWORD}

As in many parts of the world, gender-based violence is sadly not uncommon in Indian society. The National Family Health Survey 3 reported that more than one in three women in the reproductive age group in India has suffered some form of violence in her married life. Though the body of evidence on the prevalence and health consequences of violence directed against women has been slowly and surely growing in India, the evidence is scattered and often anecdotal. This review paper synthesizes and presents findings from large community- based and other research studies and addresses this evidence gap, attempting to conclusively highlight the significance of violence as a public health issue of priority concern.

The evidence base in this review paper points to disturbingly high levels of marital violenceup to $56 \%$ of women have experienced physical and/or sexual violence. What is even more alarming is that the review finds that violence continues even during pregnancy - a period when one would expect women to receive care and special attention. Not surprisingly, there is also evidence of linkages between marital violence and various health-related complications, including pregnancy-related complications, sexual and reproductive tract infections, under-nutrition among women and their children, poor mental health, and last but not the least, poor health of their children.

These data suggest that in the course of their work, India's family physicians, obstetricians, gynecologists, counselors, psychiatrists, pediatricians, and health care providers at all levels are regularly seeing women and children who have faced or are facing violence. Experiences of health care providers and data from hospitals show that orthopedic practitioners, casualty medical officers and those working in burns-wards also encounter significant numbers of women who suffer the consequences of such violence. And yet, unfortunately, medical education and the job responsibilities of health sector personnel in the country do not appear to take cognizance of this issue, neither as a major human rights violation nor as a public health issue.

This review paper is a wake-up call to those in the health field to recognize gender based violence as an issue of public health priority and to create appropriate channels to respond to this crisis. It is vital to incorporate gender based violence into the curricula of all health professions and strengthen the role of the health system in addressing issues of violence as defined in the Protection of Women from Domestic Violence Act, 2005. 
In addition, it is imperative to provide health sector personnel needed orientation and sensitization on gender based violence - how to recognize it, understand it, and empathize with survivors; to build the capacity of existing counselors, for instance, ICTC or HIV counselors, to understand the problem and provide effective counseling; and to create referral systems and other complementary services such as legal aid or short stay homes. Policies must be developed to make such services mandatory in every public health facility. We know that the health care system can do much more to address this public health crisis among women and needs to take on this responsibility in a more robust and active manner.

This review paper is a valuable document providing much-needed research evidence on the linkages between gender based violence and health in India. I take this opportunity to congratulate Dr. Shireen Jejeebhoy, Dr. K. G. Santhya and Dr. Rajib Acharya from the Population Council, New Delhi, for producing this review, which we hope will show the way forward towards a systematic health system response to marital violence in India.

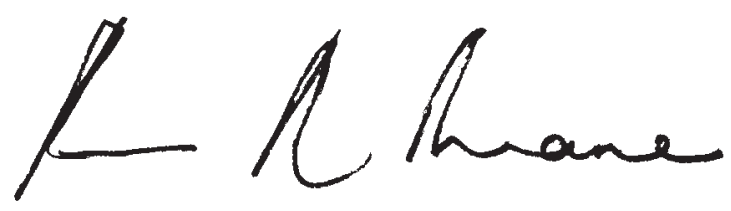

Purnima Mane, Ph D

Deputy Executive Director (Programme), United Nations Population Fund (UNFPA) and Assistant Secretary-General, United Nations 


\section{Executive summary}

Globally, one of the most common forms of violence perpetrated against women is that by their husband or an intimate male partner (Heise, Pitanguy and Germain, 1994; Krug et al., 2002). Indeed, a WHO multi-country study has suggested that the range of lifetime prevalence of physical or sexual violence, or both, was, for the most part, $30 \%$ to 60\% (Garcia-Moreno et al., 2005; 2006). In India too, marital violence is widespread. For example, National Family Health Survey-3 (NFHS-3) data indicate that 35 percent of married women aged 15-49 had experienced physical violence and 10 percent had experienced sexual violence perpetrated by their current or former husband over the course of their married life (IIPS and Macro International, 2007). What is less well established in India are the health and social consequences of violence within marriage, and particularly with regard to married young women. Indeed, available evidence is sparse and scattered, and hence it is difficult to convey the significance of the problem in terms of its impact on women's health and rights. With support from the United Nations Population Fund (UNFPA), researchers from the Population Council, New Delhi, sought to fill these gaps.

The aim of this report is to synthesise what is known about the health and social consequences of marital violence for women in India; provide new evidence, from further analysis of surveys of youth, of these consequences for young women in India; and discuss priority programmatic areas for action and themes requiring research attention. The review focuses on sexual, reproductive and child health consequences, including contraceptive use, experience of symptoms of infection, pregnancy-related care, unintended pregnancy and abortion, foetal, perinatal and early childhood mortality; maternal and child nutrition; and mental health outcomes. It also reviews evidence of a range of social outcomes including substance use, women's autonomy and self-efficacy; and inter-generational effects (witnessing parental violence when growing up). Other health consequences—chronic pain, fractures and burns, for example-are not addressed in this review.

The preparation of this synthesis involved an extensive review of published and unpublished, qualitative and quantitative studies on violence within marriage in India. It also involved further analyses of the data available to the Population Council from three major survey exercises on the situation of youth in India that enable us to link the experience of physical and sexual violence ever in marriage, in early married life and, where appropriate, in the year preceding the interview, with a range of outcomes described above.

Despite significant methodological differences, almost all studies conducted in India indicate that marital violence is a serious issue and an accepted practice. Evidence indicates that between one-tenth and half of women surveyed in various studies had experienced physical violence, and between one in twenty and one in three women had experienced sexual violence perpetrated by their husband. Sizeable proportions had experienced physical and/or sexual violence even when they were pregnant-between 
one in eight and one in two in the case of physical violence and between one in twenty and one in three in the case of sexual violence. Among young women, similarly, between one in five and three in five had experienced physical violence, and between one in ten and three in five had experienced sexual violence within marriage. Evidence available from men on the perpetration of violence also reflects the pervasiveness of marital violence, including among young men, with almost one-quarter of men reporting the perpetration of physical violence, and between one-sixth and almost one-third reporting the perpetration of sexual violence against their wife.

Evidence reiterates, moreover, the adverse health and social consequences of marital violence among women in general, and young women in particular, even after a host of socio-demographic factors are controlled. Among sexual, reproductive and child health outcomes, women who had experienced physical and/or sexual violence were more likely than others to report unwanted pregnancy; this association was observed even when young women were considered. Similarly, women - all and youngwho had experienced physical and/or sexual violence within marriage were more likely than others to have experienced symptoms of RTI/STI, and, in one study, to be HIV-positive. Finally, in many studies and settings, women who had experienced physical and/or sexual violence within marriage were significantly more likely than other women to have experienced pregnancy-related complications, and foetal, infant and child mortality. Findings from studies among young women suggest, moreover, that many of these associations are observed early in marriage, suggesting that women are at risk of ill-health for much of their married life.

Aside from sexual, reproductive and child health outcomes, the experience of physical and/or sexual violence within marriage is associated with poor mental health outcomes. These effects are consistently observed in almost all studies, covering both women in general and young women in particular.

While associations with social and behavioural factors were less consistently studied and relationships less consistently observed, there is some evidence, particularly among young women, that those who experienced marital violence were more likely than other women to report tobacco consumption and less likely to report such indicators of agency as decision-making and self-efficacy. Finally, young women who had witnessed their father beating their mother were more likely than other young women to submit to marital violence in their married life.

In a few instances, where appropriate and where data exist, associations between the perpetration of marital violence and various outcomes among men have also been explored. Findings from these studies suggest that men, including young men, who perpetrated violence on their wife were more likely than other men to report foetal, infant and child mortality. Findings among young men also suggest that those who perpetrated violence on their wife were more likely than others to report that their wife had experienced an unwanted pregnancy, and that those who had witnessed their father beating their mother 
were more likely to perpetrate violence on their wife than others.

Findings suggest several priority programmatic areas for action as well as themes and issues requiring research attention.

The consequences of marital violence, discussed in this report, highlight the need to strengthen efforts to prevent the incidence of marital violence. These initiatives should be multipronged. Activities are needed that empower women, provide them the skills, resources and opportunities to recognise risk situations and protect themselves from violence, and build life-skills from a young age. Communication skills among couples must be fostered and the need for exploring non-violent means of conflict resolution and developing egalitarian marital relationships must be highlighted. At the same time efforts must be made at the community level, among both men and women, to raise awareness of the adverse consequences of marital violence and to reduce the community's tolerance of such acts. Special attention must be paid to change deeplyentrenched inegalitarian gender norms. New norms of masculinity and femininity must be fostered. Further, norms that inhibit community members from intervening in incidents of marital violence must be changed. There is also a need to promote awareness and enforcement of laws protecting women from domestic violence.

At the same time, there is also a need to address the multiple health and social consequences of violence highlighted in this report and a top priority is to screen, identify and refer women who experience marital violence. Several manuals exist that guide providers on raising the subject of abuse with women in non-judgemental ways. Service protocols could include violence screening while recording the regular history of women seeking health care services. Screening activities must include recording a complete history of marital violence with details of the most recent and earlier episodes of violence; screening should also include a physical examination, and treatment or referral if necessary. A system to maintain follow-up contact with women who report the experience of marital violence would also need to be put in place.

Screening activities must be provided in a wide range of services. Women seeking care for adverse health consequences of marital violence may seek a number of services and it would be appropriate to establish screening mechanisms in all such services. For example, the immediate physical consequences of marital violence-abdominal/thoracic injuries, lacerations, fractures and burns_call for screening activities in emergency (casualty) services in general, as well as burns and orthopaedic-related centres.

As most women visit a health centre at some point in their life for reproductive and child health services, these centres could serve as an important focus point to identify women who experience marital violence. Our findings, showing a strong link between marital violence and RTI/STI/HIV and unmet need for contraception, call for the integration of violence screening in all sexual and reproductive health services, including family planning, ICTC and other HIV-related services. Likewise, the evidence presented in this review points to the need to address the issue of domestic violence in safe motherhood and child 
survival programmes as findings from several studies suggest that pregnancy-related care seeking could be enhanced, and a large proportion of foetal and neonatal deaths could be prevented if the incidence of marital violence is reduced. Also notable is the link between marital violence and malnutrition among women and their children. Programmes aimed at improving the nutritional status of women and children must take note of these findings; Integrated Child Development Services (ICDS) workers who play a key role in such programmes should be made aware of this link, and trained to support women experiencing marital violence. Moreover, findings highlighting the links between marital violence and adverse mental health outcomes emphasise that the National Mental Health Programme must incorporate a special focus on identifying and treating women who experience marital violence.

Women who have experienced marital violence and attend a particular service may have other health needs as well that the first point of contact is not equipped to address. It is important, therefore, that appropriate referral chains are established. While referrals could be recommended by the primary provider, appropriate mechanisms would also need to be established to ensure that abused women follow up on these referrals. Given that many abused women may not follow up on referrals recommended by their primary provider, sensitive outreach activities must be included that support women to access these services. In addition, there is a need to provide referrals to services outside the health arena, for example, legal support, shelter and so on.
To effectively meet the needs of abused women at the health facility level, provider-level barriers must be addressed. Key barriers include providers' lack of training on eliciting information and counselling women on gender-based violence, lack of time to provide related services, and providers' discomfort in communicating on the sensitive issue of marital violence with women. Indeed, provider inhibitions reflect societal norms that marital violence is "normal" and a family affair, and that providers should not intervene in domestic matters. It is important therefore that providers are given the skills needed to assist abused women. Training is needed to strengthen providers' ability to probe these issues sensitively, refer women appropriately and maintain women's confidentiality; at the same time, efforts must be made to change provider attitudes about the acceptability of marital violence. Finally, health care providers must be made aware of the laws surrounding violence against women and the sources of support available to women from sectors other than health (access to the police, the legal system, shelter, and NGOs, for example).

Findings also suggest that there is a need for further research on several issues related to marital violence. Most studies, with the exception of those using a longitudinal design, are unable to establish causality between martial violence and adverse health and social outcomes given their reliance on cross-sectional data. There is a need for more longitudinal studies, or at least cross-sectional studies that are better equipped to provide histories of both violence and reproductive health outcomes. 
While there is a growing body of evidence on associations between physical and sexual violence and health and social consequences for women, evidence remains sparse with regard to the effects of emotional violence or the threat of violence on women's health and wellbeing. Research is needed that explores these links, and notably explores the links of emotional violence and threats on women's mental health, their health care practices and care seeking behaviours, and their autonomy.

While the associations between the experience of violence and adverse outcomes are apparent, what is less clear are the pathways through which these associations take place. There is a need for research, both quantitative and qualitative, that traces these links - for example, between the experience of marital violence and infant mortality, or the unmet need for contraception, or adverse outcomes in the next generation.

At the health system level, further research is needed that explores provider attitudes and provider practices in terms of screening, counselling and treating women who have experienced marital violence. At the same time, research is required to estimate the cost of caring for women who experience adverse consequences of violence. 



\section{Introduction}

\section{Introduction and objectives}

Globally, one of the most common forms of violence perpetrated against women is that by their husband or an intimate male partner (Heise, Pitanguy and Germain, 1994; Krug et al., 2002). A synthesis of the findings of the few available studies on intimate partner violence till the 1990s suggests that between one-quarter and half of women had been physically abused by an intimate partner and many had experienced sexual coercion or forced sex perpetrated by an intimate partner (Heise, Moore, Toubia, 1995; Heise, Pitanguy and Germain, 1994). Likewise, the more recent World Health Organisation (WHO) multi-country study on women's health and domestic violence against women reports that the prevalence of physical or sexual violence against women across the 10 countries in which the study was undertaken ranged from 15\% (Japan City) to 71\% (rural Ethiopia), and, for the most part, from $30 \%$ to $60 \%$ (Garcia-Moreno et al., 2005; 2006). The adverse health consequences of intimate partner violence have increasingly been recognised and are observed to be profound. Indeed, World Bank estimates in the 1990s indicate that rape and domestic violence accounted for $5 \%$ of the healthy years of life lost to women of reproductive age in developing countries, and that globally, the health burden of gender-based violence on women was comparable to that posed by such diseases as HIV, tuberculosis, sepsis during pregnancy, cancer and cardiovascular disease (Heise, Pitanguy and Germain, 1994 quoting World Bank, 1993).
In India, marital violence is widespread and perceived to be acceptable by many. For example, National Family Health Survey-3 (NFHS-3) data indicate that $35 \%$ of married women aged 15-49 had experienced physical violence and 10\% had experienced sexual violence perpetrated by their current or former husband over the course of their married life (IIPS and Macro International, 2007). What is less well established are the health and social consequences of violence within marriage, and particularly with regard to married young women in India. Indeed, available evidence is sparse and scattered, and hence it is difficult to convey the significance of the problem in terms of its impact on women's health and rights. There is a need therefore to consolidate available evidence and provide a composite picture of the extent of marital violence, particularly among young women, and determine the health and social consequences of the experience of violence. The objectives of this report are twofold: to synthesise what is known about the health and social consequences of marital violence for women in India; and to provide new evidence, from further analysis of surveys of youth, of these consequences for young women in India.

The review first provides a framework for the analysis of the consequences of intimate partner violence. It then reviews the available evidence on the prevalence of marital violence- $-\mathrm{a}$ key aspect of intimate partner violence-and on the multiple consequences of marital violence experienced by women of reproductive age in India, drawing from 
large- and small-scale, and both quantitative and qualitative studies. It follows this up with a discussion of new evidence on the consequences of marital violence among young women in India drawn from surveys of youth. The report concludes with a discussion of the priority programmatic areas for action as well as themes requiring research attention.

\section{Definitions and consequences of intimate partner violence: Framework for analysis}

The World Health Report (Krug et al., 2002) has defined intimate partner violence as encompassing any behaviour within an intimate relationship that causes physical, psychological or sexual harm to those in the relationship. Physical violence refers to any act of physical aggression, including slapping, beating, kicking, or threatening with a knife, gun or other object. Sexual violence includes forced intercourse and other forms of sexual coercion, including threats of abandonment or physical violence. Psychological abuse-usually accompanying physical and sexual violence-includes intimidation and humiliation. Violence also includes such controlling behaviours as isolating women from their natal family, monitoring their movements and restricting their access to information or assistance (Krug et al., 2002).

Research reported in the World Health Report (Krug et al., 2002) highlights that intimate partner violence is pervasive and severe. For one, various types of abuse generally coexist in the same relationship; for example, for women who experience physical violence in intimate relationships, violence is often accompanied-in one-third to over one half of cases-by sexual violence. Second, the experience of intimate partner violence is not, for the most part, an isolated event; indeed, women who experience violence experience multiple acts of violence. And third, among those experiencing violence, large proportions report severe abuse.

Drawing on the available global literature, notably the World Health Report (Krug et al., 2002), the WHO multi-country study on women's health and domestic violence (Garcia-Moreno et al., 2005), and a review of intimate partner violence among couples in 10 countries (Hindin, Kishor and Ansara, 2008), Table 1.1 summarises the consequences of intimate partner violence and highlights that violence affects many aspects of women's health and life. These studies indicate that the consequences of intimate partner violence are both immediate and long-term, and can be regarded as risk factors for a variety of diseases and conditions. The literature highlights, moreover, that the effects of violence can persist long after the abuse has stopped, and the more severe the abuse, the greater is its impact on women's physical and mental health.

Aside from the health consequences of violence, a number of social consequences have been identified in the literature, many of which have implications for the health of women and their children. The experience of violence has been linked with smoking, and alcohol and drug abuse among women. It has also been observed to be associated with women's limited autonomy and low self-esteem. Studies exploring these linkages are, however, unable to unequivocally establish the direction of the causal link; the literature hypothesises that women who have experienced violence may be inhibited from making decisions and lack the self-efficacy with which to take action, 


\section{Table 1.1:}

Health and social consequences of intimate partner violence for women

\section{A. Health consequences}

\section{Physical consequences}

Abdominal/thoracic injuries

Bruises and welts

Chronic pain syndrome

Fibromyalgia

Fractures

Gastrointestinal disorders

Irritable bowel syndrome

Lacerations and abrasions

Ocular damage

Loss of memory, dizziness

Reduced physical functioning

Low body mass index (BMI)

\section{Sexual, reproductive and child health consequences}

Infertility

Vaginal discharge

Pelvic inflammatory disease

Reproductive tract/sexually transmitted infections (RTIs/STIs), including HIV

Sexual dysfunction

Limited practice of contraception

Closely spaced pregnancies

Unintended pregnancy

Unsafe abortion

Limited pregnancy-related care

Pregnancy complications

Miscarriage

Child malnutrition and lack of immunisation

\section{Psychological consequences}

Depression and anxiety

Eating and sleep disorders

Feelings of shame and guilt

Phobias and panic disorders

Physical inactivity

Post-traumatic stress disorders

Suicidal behaviour and self-harm 
Table 1.1: (Cont'd)

\section{A. Health consequences}

Fatal health consequences

Foetal mortality

Infant and child mortality

AIDS-related mortality

Maternal mortality

Homicide

Suicide

B. Social consequences

Smoking

Alcohol and drug abuse

Limited autonomy

Low self-esteem

Inter-generational consequences: Emotional and behavioural

Problems among children

Inability to perform wage work/housework

Economic costs

Source: Garcia-Moreno et al., 2005; Hindin, Kishor and Ansara, 2008; Krug et al., 2002.

including in situations relating to seeking health care for themselves and their children. Inter-generational consequences have also been observed, with children who witness parental violence more at risk than other children of experiencing a range of emotional and behavioural problems, as well as, in adulthood, more at risk than others of perpetrating (men) and submitting to (women) intimate partner violence themselves. In addition, violence is observed to place an economic burden on women, forcing them to forego work and wages, and making them unable to perform household duties. While violence can have serious health and social consequences, evidence relating to several of these remains limited.

\section{Methodology}

In preparing this report, we first reviewed published and unpublished, qualitative and quantitative studies on violence within marriage and its consequences in India. Most studies that have addressed the consequences of violence are cross-sectional; they are unable to establish the temporality of events and thus causality. These studies can however, establish associations between the experience of physical and/or sexual violence and adverse health and social outcomes. There are, however, several studies that have succeeded in reducing or eliminating this ambiguity. Some, using cross-sectional study designs, have explored the association between violence experienced at an early stage in marital life and health consequences experienced more recently. Others have employed longitudinal study designs that have been able to interview women at several points in their life. Studies employing both crosssectional and longitudinal study designs are included in this review. 
We also conducted further analyses of the data available from three major survey exercises on the situation of youth in India. These include:

(a) Youth in India: Situation and Needs study: The Youth Study is the first ever sub-nationally representative study of the key transitions experienced by married and unmarried young women and men in India. Data on the experience and perpetration of marital violence are available from some 13,500 married young women aged 15-24 and some 8,000 married young men aged 15-29, respectively, from six states, namely, Andhra Pradesh, Bihar, Jharkhand, Maharashtra, Rajasthan and Tamil Nadu (IIPS and Population Council, 2010).

(b) Study on the Formation and Experience of Sexual Partnership among Youth: The study was conducted among married and unmarried females and males aged 15-24 in selected sites of Pune district, Maharashtra. Data on the experience and perpetration of marital violence are available from 2,306 married young women and 1,019 married young men, respectively (Alexander et al., 2006).

(c) Study on Understanding and Addressing HIV and Sexual and Reproductive Health Risks of Married Young People: The study was conducted among married young women aged 15-24 and married young men aged 15-29 in Guntur district, Andhra Pradesh, and Dhar and Guna districts, Madhya Pradesh. Data are available from some 3,000 married young women and some 2,500 married young men (Santhya, Jejeebhoy and Ghosh, 2008).

Data from these studies enable us to link the experience of physical and sexual violence ever in marriage, in early married life and, where appropriate, in the year preceding the interview, with a range of sexual, reproductive and child health outcome indicators relating to contraceptive use, experience of symptoms of infection, pregnancyrelated care, unintended pregnancy and abortion, foetal, perinatal and early childhood mortality; with maternal and child nutrition; and with mental health outcomes. It also enables us to link the experience of violence with a range of social outcomes including substance use, women's autonomy and self-efficacy and inter-generational effects (witnessing parental violence when growing up). Multivariate analysis was performed to assess associations between the experience of physical and sexual violence within marriage and each outcome measure, controlling for such confounding factors as age, household economic status, rural-urban residence, educational attainment levels and economic activity status.

We start by acknowledging the limitations of this report. First, though women experience violence within both marital and non-marital relationships, our discussion focuses only on marital violence as the majority of women in India experience sexual partnership within marriage. Second, although emotional/psychological violence is a major dimension of violence within marriage, the report focuses only on physical and sexual violence within marriage. Third, while the most common and obvious consequence of marital violence are injuries, ranging from cuts and bruises to deep wounds, broken bones and burns (see Kishor and Gupta, 2009), this report does not address these immediate consequences of marital violence. 


\section{CHAPTER 2}

\section{Marital violence in India: The situation}

This chapter summarises findings from available studies conducted in India that report the extent of physical and/or sexual violence within marriage. These studies include community-based studies of ever or currently married women (aged 15-50) in general and special groups such as pregnant women, as well as facility-based studies primarily of pregnant women, but also of those seeking voluntary testing and counselling (VCT) services and those attending a psychiatric out-patient facility. They also include a small number of studies of men (aged 15-65) who reported that they perpetrated violence against their wife. Despite significant methodological differences, almost all studies conducted in India indicate that domestic violence is a serious issue and an accepted practice within marriage.
Table 2.1 shows that between one-tenth and half of women surveyed in various studies had experienced physical violence, primarily perpetrated by their husband. Far fewer studies have explored women's experience of sexual violence; these studies show that between one in twenty and one in three women had experienced such violence in marriage. Findings, moreover, suggest that sizeable proportions of women experienced physical and/or sexual violence even when they were pregnant-between one in eight and one in two in the case of physical violence and between one in twenty and one in three in the case of sexual violence.

\section{Table 2.1:}

Magnitude of lifetime experience (women aged 15-50) of physical and/or sexual violence within marriage: Findings from various studies, 1990s-2000s

\begin{tabular}{|c|c|c|c|c|c|}
\hline \multirow[t]{2}{*}{ Site } & \multirow[t]{2}{*}{ Population selected } & \multirow{2}{*}{$\begin{array}{l}\text { Sample } \\
\text { size }\end{array}$} & \multicolumn{2}{|c|}{$\%$ experienced within marriage } & \multirow[t]{2}{*}{ Source } \\
\hline & & & $\begin{array}{l}\text { Physical } \\
\text { violence }\end{array}$ & $\begin{array}{c}\text { Sexual } \\
\text { violence }\end{array}$ & \\
\hline \multicolumn{6}{|l|}{ Community-based studies } \\
\hline India & $\begin{array}{l}\text { Ever-married women aged } \\
15-49 \text {, nation-wide }\end{array}$ & 66,658 & 35 & 10 & $\begin{array}{l}\text { IIPS and Macro } \\
\text { International, } 2007\end{array}$ \\
\hline $\begin{array}{l}\text { Karnataka (3 villages, } \\
\text { south-eastern region) }\end{array}$ & $\begin{array}{l}\text { Ever-married women } \\
\text { aged above } 15 \text {, potter } \\
\text { community }\end{array}$ & 170 & 22 & & Rao, 1998 \\
\hline $\begin{array}{l}\text { Tamil Nadu Uttar } \\
\text { Pradesh (2 districts each) }\end{array}$ & $\begin{array}{l}\text { Currently married women } \\
\text { aged } 15-39 \text {, rural }\end{array}$ & 1,842 & $\begin{array}{r}\text { Tamil Nadu=37 } \\
\text { Uttar Pradesh }=45\end{array}$ & & Jejeebhoy, 1998a \\
\hline Goa (Aldona) & $\begin{array}{l}\text { Currently married women } \\
\text { aged } 18-50 \text {, catchment } \\
\text { area of a primary health } \\
\text { centre }\end{array}$ & 1,750 & 9 & 4 & $\begin{array}{l}\text { Chowdhary and Patel, } \\
2008\end{array}$ \\
\hline
\end{tabular}


Table 2.1: (Cont'd)

\begin{tabular}{|c|c|c|c|c|c|}
\hline \multirow[t]{2}{*}{ Site } & \multirow[t]{2}{*}{ Population selected } & \multirow{2}{*}{$\begin{array}{l}\text { Sample } \\
\text { size }\end{array}$} & \multicolumn{2}{|c|}{$\%$ experienced within marriage } & \multirow[t]{2}{*}{ Source } \\
\hline & & & $\begin{array}{l}\text { Physical } \\
\text { violence }\end{array}$ & $\begin{array}{c}\text { Sexual } \\
\text { violence }\end{array}$ & \\
\hline $\begin{array}{l}\text { Orissa, West Bengal, } \\
\text { Jharkhand ( } 4 \text { districts in } \\
\text { each state) }\end{array}$ & $\begin{array}{l}\text { Married women (not } \\
\text { indicated whether ever or } \\
\text { currently married) aged } \\
<50 \text {, rural and urban }\end{array}$ & 1,715 & $16^{1}$ & 25 & Babu and Kar, 2009 \\
\hline Chandigarh & $\begin{array}{l}\text { Currently married women } \\
\text { of reproductive age (age } \\
\text { not specified), peri-urban } \\
\text { area, slums }\end{array}$ & 296 & $39^{1}$ & & Agarwal et al., 2009 \\
\hline $\begin{array}{l}\text { Gujarat ( } 5 \text { villages of } \\
\text { Kheda district) }\end{array}$ & $\begin{array}{l}\text { Currently married women } \\
\text { with at least one child } \\
\text { aged }<3 \text { years }\end{array}$ & 346 & 42 & & Visaria, 2000 \\
\hline $\begin{array}{l}\text { Kerala } \\
\text { (Thiruvananthapuram) }\end{array}$ & $\begin{array}{l}\text { Ever-married women aged } \\
15-49 \text {, rural and urban }\end{array}$ & 502 & 36 & & $\begin{array}{l}\text { Panda and Agarwal, } \\
2005\end{array}$ \\
\hline Karnataka (Mysore) & $\begin{array}{l}\text { Women (age and marital } \\
\text { status not specified) with } \\
\text { at least one child aged } \\
6-24 \text { months, rural and } \\
\text { tribal areas }\end{array}$ & 820 & 34 & & Sethuraman, 2008 \\
\hline $\begin{array}{l}\text { Karnataka (one taluk in } \\
\text { the central plateau region) }\end{array}$ & $\begin{array}{l}\text { Currently married women } \\
\text { aged } 15-50 \text {, rural }\end{array}$ & 397 & 29 & 12 & Krishnan, 2005 \\
\hline Maharashtra (Nagpur) & $\begin{array}{l}\text { Ever-married women with } \\
\text { at least one child }<18 \\
\text { years, rural }\end{array}$ & 500 & $17-48$ & & Jain et al., 2004 \\
\hline West Bengal (Kolkata) & $\begin{array}{l}\text { Currently married women } \\
\text { aged } 15-45 \text {, urban slum }\end{array}$ & 751 & $18^{3}$ & & Pandey et al., 2009 \\
\hline $\begin{array}{l}\text { Bhopal, Chennai, Delhi, } \\
\text { Lucknow, Nagpur, } \\
\text { Thiruvananthapuram, } \\
\text { Vellore }\end{array}$ & $\begin{array}{l}\text { Ever-married women, aged } \\
15-49 \text { with at least one } \\
\text { child }<18 \text { years, rural, } \\
\text { urban slum and urban } \\
\text { non-slum }\end{array}$ & 9,938 & 40 & & ICRW, 2000 \\
\hline Maharashtra (Mumbai) & $\begin{array}{l}\text { Currently married women, } \\
\text { urban slum, aged }>18 \\
\text { (drawn from voters' list) }\end{array}$ & 553 & 43 & & $\begin{array}{l}\text { Verma and } \\
\text { Collumbien, } 2003\end{array}$ \\
\hline \multicolumn{6}{|c|}{ Community- and facility-based studies, pregnant women } \\
\hline $\begin{array}{l}\text { Uttar Pradesh ( } 28 \\
\text { districts) }\end{array}$ & $\begin{array}{l}\text { Currently married women } \\
\text { of reproductive age (exact } \\
\text { ages not specified) who } \\
\text { had a pregnancy outcome } \\
\text { in the } 3 \text { years preceding } \\
\text { the survey }\end{array}$ & 2,199 & 18 & & $\begin{array}{l}\text { Ahmed, Koenig, } \\
\text { Stephenson, } 2006\end{array}$ \\
\hline
\end{tabular}

Cont'd on next page... 
Table 2.1: (Cont'd)

\begin{tabular}{|c|c|c|c|c|c|}
\hline \multirow[t]{2}{*}{ Site } & \multirow[t]{2}{*}{ Population selected } & \multirow{2}{*}{$\begin{array}{l}\text { Sample } \\
\text { size }\end{array}$} & \multicolumn{2}{|c|}{$\%$ experienced within marriage } & \multirow[t]{2}{*}{ Source } \\
\hline & & & $\begin{array}{l}\text { Physical } \\
\text { violence }\end{array}$ & $\begin{array}{c}\text { Sexual } \\
\text { violence }\end{array}$ & \\
\hline $\begin{array}{l}\text { Bhopal, Chennai, Delhi, } \\
\text { Lucknow, Nagpur, } \\
\text { Thirvananthapuram, } \\
\text { Vellore }\end{array}$ & $\begin{array}{l}\text { Ever-married women, aged } \\
15-49 \text { with at least one } \\
\text { child }<18 \text { years, rural, } \\
\text { urban slum and urban } \\
\text { non-slum }\end{array}$ & 9,938 & 18 & & Peedicayil et al., 2004 \\
\hline Chandigarh & $\begin{array}{l}\text { Currently married women } \\
\text { (age not specified) seeking } \\
\text { antenatal care, tertiary } \\
\text { hospital }\end{array}$ & 991 & $28^{1,4}$ & & Khosla et al., 2005 \\
\hline Goa (Mapusa) & $\begin{array}{l}\text { Currently married women } \\
\text { (age not specified) seeking } \\
\text { antenatal care in the last } \\
\text { trimester of pregnancy } \\
\text { and followed up at } 6-8 \\
\text { weeks and } 6 \text { months after } \\
\text { delivery, tertiary hospital }\end{array}$ & 270 & $\begin{array}{r}13 \text { (ever) and } 6 \\
\text { (during pregnancy) }^{5}\end{array}$ & & $\begin{array}{l}\text { Patel, Rodrigues and } \\
\text { DeSouza, } 2002\end{array}$ \\
\hline Maharashtra (Nagpur) & $\begin{array}{l}\text { Currently married women } \\
\text { (age not specified) seeking } \\
\text { antenatal care ( } 28-40 \\
\text { weeks of pregnancy), } \\
\text { secondary and tertiary } \\
\text { hospitals }\end{array}$ & 600 & $22^{1}$ & & Purwar et al., 1999 \\
\hline Maharashtra (Sevagram) & $\begin{array}{l}\text { Currently married } \\
\text { pregnant women (age not } \\
\text { specified) seeking antenatal } \\
\text { care or other services at a } \\
\text { health facility }\end{array}$ & 2,000 & $48^{1}$ & & Chhabra, 2007 \\
\hline Maharashtra (Sevagram) & $\begin{array}{l}\text { Currently married } \\
\text { pregnant women (age not } \\
\text { specified) seeking antenatal } \\
\text { care or other services at a } \\
\text { health facility }\end{array}$ & 2,000 & & $31^{5}$ & Chhabra, 2008 \\
\hline Delhi & $\begin{array}{l}\text { Currently married women } \\
(93 \% \text { aged }<40) \text { seeking } \\
\text { antenatal care }(96 \% \\
\text { were currently married; } \\
\text { rest were unmarried or } \\
\text { divorced) }\end{array}$ & 500 & $27^{1,6}$ & 6 & Singh et al., 2008 \\
\hline Delhi & $\begin{array}{l}\text { Currently married women } \\
\text { (age not specified) who } \\
\text { had delivered in a tertiary } \\
\text { hospital }\end{array}$ & 800 & $21^{1}$ & & $\begin{array}{l}\text { Muthal-Rathore, } \\
\text { Tripathi and Arora, } \\
2002\end{array}$ \\
\hline
\end{tabular}

Cont'd on next page... 
Table 2.1: (Cont'd)

\begin{tabular}{|c|c|c|c|c|c|}
\hline \multirow[t]{2}{*}{ Site } & \multirow[t]{2}{*}{ Population selected } & \multirow{2}{*}{$\begin{array}{l}\text { Sample } \\
\text { size }\end{array}$} & \multicolumn{2}{|c|}{$\%$ experienced within marriage } & \multirow[t]{2}{*}{ Source } \\
\hline & & & $\begin{array}{l}\text { Physical } \\
\text { violence }\end{array}$ & $\begin{array}{c}\text { Sexual } \\
\text { violence }\end{array}$ & \\
\hline Karnataka (Bangalore) & $\begin{array}{l}\text { Currently married women } \\
\text { aged } 18-49 \text { seeking } \\
\text { antenatal care in a public } \\
\text { hospital }\end{array}$ & 203 & $14^{3}$ & 9 & Varma et al., 2007 \\
\hline \multicolumn{6}{|c|}{ Facility-based studies, special groups } \\
\hline Karnataka (Bangalore) & $\begin{array}{l}\text { Currently married women } \\
\text { aged } 18-45 \text {, seeking } \\
\text { voluntary testing and } \\
\text { counselling (VCT) services }\end{array}$ & 245 & 29 & 1 & $\begin{array}{l}\text { Chandrasekaran } \\
\text { et al., } 2007\end{array}$ \\
\hline Karnataka (Bangalore) & $\begin{array}{l}\text { Currently married women } \\
\text { aged } 18-49 \text { attending } \\
\text { a psychiatry out-patient } \\
\text { facility }^{6}\end{array}$ & $105^{7}$ & 49 & 39 & $\begin{array}{l}\text { Chandra, } \\
\text { Satyanarayana and } \\
\text { Carey, } 2009\end{array}$ \\
\hline
\end{tabular}

${ }^{1}$ Includes physical violence perpetrated by persons other than husband; ${ }^{2}$ Includes physical and psychological abuse; ${ }^{3}$ Refers to experiences in the 1 year preceding the interview; ${ }^{4}$ Includes physical, sexual and verbal abuse; ${ }^{5}$ Not specified whether the measure includes physical or sexual violence, or both forms of violence; ${ }^{6}$ Not specified whether experienced/perpetrated during lifetime or during pregnancy; ${ }^{7}$ Recalculated from figures provided in the article, excluding experience of psychological violence.

While only a handful of studies, presented in Table 2.2, have gathered data on men's reports of perpetration of violence against their wife, they also reflect the pervasiveness of marital violence. Between one-fifth and two-fifths of men had perpetrated physical violence, and between one-sixth and almost one-third had perpetrated sexual violence, against their wife.

\section{Table 2.2:}

Magnitude of lifetime perpetration (men aged 15-65) of physical and/or sexual violence within marriage: Findings from various studies, 1990s-2000s

\begin{tabular}{|c|c|c|c|c|c|}
\hline \multirow[t]{2}{*}{ Site } & \multirow[t]{2}{*}{ Population selected } & \multirow[t]{2}{*}{ Sample size } & \multicolumn{2}{|c|}{$\begin{array}{c}\% \text { perpetrated within } \\
\text { marriage }\end{array}$} & \multirow[t]{2}{*}{ Source } \\
\hline & & & $\begin{array}{l}\text { Physical } \\
\text { violence }\end{array}$ & $\begin{array}{c}\text { Sexual } \\
\text { violence }\end{array}$ & \\
\hline $\begin{array}{l}\text { Uttar Pradesh ( } 400 \text { villages } \\
\text { and towns in } 5 \text { districts) }\end{array}$ & $\begin{array}{l}\text { Currently married men } \\
\text { aged } 15-65 \text {, rural and } \\
\text { urban }\end{array}$ & 6,632 & 24 & 29 & $\begin{array}{l}\text { Martin et } \\
\text { al., } 1999\end{array}$ \\
\hline $\begin{array}{l}\text { Orissa, West Bengal, } \\
\text { Jharkhand ( } 4 \text { districts in } \\
\text { each state) }\end{array}$ & $\begin{array}{l}\text { Married men (not indicated } \\
\text { whether ever or currently } \\
\text { married) aged }<50 \text {, rural } \\
\text { and urban }\end{array}$ & 1,715 & 22 & 17 & $\begin{array}{l}\text { Babu and } \\
\text { Kar, } 2009\end{array}$ \\
\hline $\begin{array}{l}\text { Gujarat ( } 5 \text { villages of } \\
\text { Kheda district) }\end{array}$ & $\begin{array}{l}\text { Currently married men } \\
\text { with at least one child aged } \\
<3 \text { years }\end{array}$ & 377 & 42 & & Visaria, 2002 \\
\hline
\end{tabular}


Until recently, marital violence among married youth was poorly explored. Several recent studies have, however, shed light on the experiences of youth; these studies include those that specifically focused on married young people as well as those that focused on adult women in general but included small samples of young women. Findings of studies focused on the experience of young women are provided in Table 2.3. In general, between one-fifth and slightly less than three-fifths of young women had experienced physical violence and between one-tenth and slightly less than three-fifths had experienced sexual violence within marriage.

\section{Table 2.3:}

Magnitude of lifetime experience (young women) of physical and/or sexual violence within marriage: Findings from various surveys and studies, 2000s

Site
India
India (6 states)
Bihar
Jharkhand
Rajasthan
Maharashtra
Andhra Pradesh
Tamil Nadu
Pune district, Maharashtra
Kerala (Thiruvananthapuram)
Jhissa, West Bengal,
state)
Guntur district, Andhra
Pradesh
Dhar and Guna districts,
Madhya Pradesh
Bangalore, Karnataka
(istricts of each
Mand

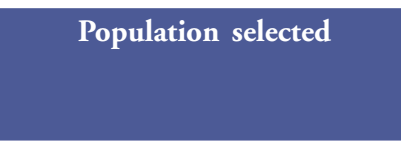

Ever-married women aged 15-19 and 20-24, nation-wide

Currently married women aged 15-24, state-wide

Currently married women aged 15-24, rural and urban slum

Currently married women aged 15-24, rural

Currently married women aged 16-25, low-income communities

Married women aged $<20$ (not specified whether ever or currently married), rural and urban

Ever-married women aged $15-24$, rural and urban

\section{Sample size (a)}

$4,643 \&$

11,642 , respectively

13,912

2,341

2,684

2,603

1,947

2,330

2,007

2,306

1,370

33.6

1,717

41.2

29.7

27.0

18.4

26.9

22.9

27.0

21.0

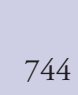

744

126

2.4

7.9

| Sexual

Sexual

vience

13.1

10.5

32.2

53.7

39.7

39.8

27.3

10.2

25.3

14.9

44.2

56.3

\section{Source}

IIPS and Macro

International, 2007

IIPS and Population Council, 2010

Acharya and Jejeebhoy, 2008;

Alexander et al., 2006

Santhya, Jejeebhoy and Ghosh, 2008

Rocca et al., 2009

Babu and Kar, 2009

Panda and Agarwal, 2005 


\section{Table 2.4:}

Magnitude of lifetime perpetration (young men) of physical and/or sexual violence within marriage: Findings from various surveys and studies, 2000s

\begin{tabular}{|c|c|c|c|c|c|}
\hline \multirow[t]{2}{*}{ Site } & \multirow{2}{*}{ Population selected } & \multirow[t]{2}{*}{ Sample size } & \multicolumn{2}{|c|}{$\%$ perpetrated } & \multirow[t]{2}{*}{ Source } \\
\hline & & & $\begin{array}{l}\text { Physical } \\
\text { violence }\end{array}$ & $\begin{array}{c}\text { Sexual } \\
\text { violence }\end{array}$ & \\
\hline India (6 states) & $\begin{array}{l}\text { Currently married men } \\
\text { aged } 15-29 \text {, state-wide }\end{array}$ & 8,052 & 23.9 & 16.7 & $\begin{array}{l}\text { IIPS and Population } \\
\text { Council, } 2010\end{array}$ \\
\hline Bihar & & 1,115 & 29.7 & 24.8 & \\
\hline Jharkhand & & 1,259 & 27.0 & 23.3 & \\
\hline Rajasthan & & 1,886 & 13.5 & 17.2 & \\
\hline Maharashtra & & 1,065 & 24.8 & 8.5 & \\
\hline Andhra Pradesh & & 1,405 & 19.7 & 14.7 & \\
\hline Tamil Nadu & & 1,322 & 34.3 & 14.7 & \\
\hline Pune district, Maharashtra & $\begin{array}{l}\text { Currently married men } \\
\text { aged } 15-24 \text {, rural and } \\
\text { urban slum }\end{array}$ & 1,019 & 23.9 & 8.5 & $\begin{array}{l}\text { Acharya and Jejeebhoy, } \\
\text { 2008; Alexander et al., } \\
2006\end{array}$ \\
\hline $\begin{array}{l}\text { Guntur district, Andhra } \\
\text { Pradesh }\end{array}$ & $\begin{array}{l}\text { Currently married men } \\
\text { aged } 15-29 \text {, rural }\end{array}$ & 1,075 & 40.8 & 9.6 & $\begin{array}{l}\text { Santhya, Jejeebhoy and } \\
\text { Ghosh, } 2008\end{array}$ \\
\hline $\begin{array}{l}\text { Dhar and Guna districts, } \\
\text { Madhya Pradesh }\end{array}$ & & 1,547 & 32.6 & 36.0 & \\
\hline
\end{tabular}

Young men's reports of perpetration of violence within marriage, presented in Table 2.4, indicate that between one-seventh and two-fifths had ever perpetrated physical violence and between one-tenth and one-third had ever perpetrated sexual violence on their wife.

A comparison of the findings of studies among women and men of all ages, and young women and men in particular (Tables 2.1 and 2.2 versus Tables 2.3 and 2.4), does not show huge variations in the proportions reporting experiencing (women) or perpetrating (men) violence within marriage. These findings suggest that marital violence is initiated relatively early in marriage. 


\section{CHAPTER 3}

\section{Marital violence and sexual and reproductive health consequences}

This section explores the association between women's experience of physical or sexual violence perpetrated by their husband and health-related outcomes for women and children. The health outcomes examined include (a) modern contraceptive use, (b) unintended pregnancy and abortion, (c) reproductive tract infections (RTIs) and sexually transmitted infections (STIs), including HIV, (d) pregnancy-related care seeking and complications, and (e) child health outcomes. Many of these associations are suggestive rather than conclusive; a key limitation of most studies is their cross-sectional nature and corresponding difficulty in establishing the temporal ordering of domestic violence and health outcomes. For each outcome, we first present evidence from available studies, and follow it up with new evidence from a further analysis of data from surveys that specifically focused on young people.

\section{Modern contraceptive use}

A cross-sectional logistic regression analysis of NFHS-3 data suggests that, after controlling for education, wealth status and children ever born, women who had experienced both physical and sexual violence were significantly less likely than those who had experienced neither form of violence to practise contraception; in contrast, women who had experienced only physical violence or only sexual violence were no less likely than those who had not experienced any violence to have done so (Kishor and Gupta, 2009). Because it is not possible to establish the temporal ordering of marital violence and contraceptive use, it is difficult to attribute causality to this relationship.

Two studies that overcame temporal ambiguities suggest an inverse association between physical violence within marriage and contraceptive practice (see Table 3.1). One of these studies explored the association between the experience of marital physical violence and the subsequent adoption of contraception among a representative sample of women of reproductive age in Uttar Pradesh. The study explored the contraceptive histories of women who were not practising contraception and who had at least one living child at the start of a threeyear period in which contraceptive histories were recorded. Findings, using hazards ratios, show that women who experienced physical violence were 2.1 times less likely subsequently to adopt contraception than women who were not exposed to violence, even after controlling for a host of socio-demographic indicators, health infrastructure and individual and community gender-role norms (Stephenson, Koenig and Ahmed, 2006a). The second is a longitudinal study that explored these associations, using data from the NFHS-2 (1998-99) and a follow-up survey of women in four states (Bihar, Jharkhand, Maharashtra and Tamil Nadu) conducted in 2002-03. Analysis was conducted among a sample of 3,234 women who were interviewed at the time of the NFHS-2 survey, had at least one child and 
were not practising any form of contraception at the time. The experience of physical violence was measured by whether the woman had experienced physical violence perpetrated by her husband in the 12 months preceding the survey; contraceptive adoption was measured by whether a woman had adopted a non-terminal or terminal method during the intervening period. Findings show that women who experienced physical violence at the time of the NFHS-2 were significantly less likely (OR 0.85) than those who did not to have adopted contraception in the intervening period, even after such factors as parity, presence of a living son, educational attainment levels of women and their husband,

\section{Table 3.1:}

Association between marital violence and contraceptive practice: Findings from various studies, 1990s-2000s

\begin{tabular}{|c|c|c|c|c|c|c|}
\hline Site & $\begin{array}{l}\text { Population } \\
\text { selected }\end{array}$ & $\begin{array}{l}\text { Type of } \\
\text { analysis }\end{array}$ & $\begin{array}{c}\text { Health } \\
\text { outcome } \\
\text { measure used }\end{array}$ & $\begin{array}{c}\text { Violence } \\
\text { measure used }\end{array}$ & $\begin{array}{l}\text { Direction } \\
\text { of } \\
\text { association }\end{array}$ & Source \\
\hline $\begin{array}{l}\text { India } \\
\text { (NFHS-3) }\end{array}$ & $\begin{array}{l}\text { Ever-married } \\
\text { women aged } \\
15-49 \text {, nation-wide }\end{array}$ & $\begin{array}{l}\text { Cross-sectional, } \\
\text { multivariate }\end{array}$ & $\begin{array}{l}\text { Current use } \\
\text { of modern } \\
\text { contraception }\end{array}$ & $\begin{array}{l}\begin{array}{l}\text { Experience of } \\
\text { physical violence } \\
\text { only }\end{array} \\
\text { Experience of } \\
\text { sexual violence } \\
\text { only } \\
\text { Experience of } \\
\text { physical and } \\
\text { sexual violence }\end{array}$ & (NS) & $\begin{array}{l}\text { Kishor and } \\
\text { Gupta, } 2009\end{array}$ \\
\hline $\begin{array}{l}\text { Uttar Pradesh } \\
\text { (5 districts) }\end{array}$ & $\begin{array}{l}\text { Currently married } \\
\text { women aged 15-45 } \\
\text { with at least one } \\
\text { child and not using } \\
\text { contraception at the } \\
\text { start of the 3-year } \\
\text { period prior to the } \\
\text { survey and their } \\
\text { husband }\end{array}$ & $\begin{array}{l}\text { Cross-sectional, } \\
\text { multivariate }\end{array}$ & $\begin{array}{l}\text { Contraceptive } \\
\text { use (modern } \\
\text { methods) } \\
\text { during the } \\
\text { 3-year period } \\
\text { preceding the } \\
\text { survey }\end{array}$ & $\begin{array}{l}\text { Experience of } \\
\text { physical violence } \\
\text { initiated prior to } \\
\text { the adoption of } \\
\text { contraception }^{\mathrm{a}}\end{array}$ & $(-)$ & $\begin{array}{l}\text { Stephenson } \\
\text { Koenig and } \\
\text { Ahmed, 2006a }\end{array}$ \\
\hline $\begin{array}{l}\text { Bihar, } \\
\text { Jharkhand, } \\
\text { Maharashtra, } \\
\text { Tamil Nadu }\end{array}$ & $\begin{array}{l}\text { Currently married } \\
\text { women aged 15-49 } \\
\text { with at least one } \\
\text { child and not using } \\
\text { contraception at the } \\
\text { time of NFHS-2, } \\
\text { and followed up } \\
\text { in } 2002-03 \text {, rural, } \\
\text { state-wide }\end{array}$ & $\begin{array}{l}\text { Longitudinal, } \\
\text { multivariate }\end{array}$ & $\begin{array}{l}\text { Contraceptive } \\
\text { use (modern } \\
\text { methods) } \\
\text { during the } \\
\text { inter-survey } \\
\text { period }\end{array}$ & $\begin{array}{l}\text { Experience of } \\
\text { physical violence } \\
\text { in the } 1 \text { year } \\
\text { preceding the } \\
\text { baseline }\end{array}$ & $(-)$ & $\begin{array}{l}\text { Stephenson et } \\
\text { al., } 2008\end{array}$ \\
\hline
\end{tabular}

${ }^{a}$ Women's experience of physical andlor sexual violence was measured by the husband's reports of perpetration of marital violence. $(N S)=$ Not significant; $(+)=$ significant positive association, $p<=0.05 ;(-)=$ significant negative association, $p<=0.05$. 
decision-making power, household assets and state of residence were controlled (Stephenson et al., 2008).

Findings presented in Table 3.2, drawing on cross-sectional data from young women (aged 15-24) in a number of surveys, show the association between modern contraceptive use and women's experience of violence in married life, after controlling for a range of socio-demographic factors. Temporal ambiguities are countered in two ways. First, the measure of physical violence reflects experiences in early married life, namely, physical violence within the first year of marriage and sexual violence at initiation. Second, analysis of the association between physical violence and contraception was restricted to women who had not practised contraception before their first pregnancy as a proxy for contraceptive adoption subsequent to the experience of violence.

Findings suggest that current contraceptive use was by and large unrelated with young women's experience of physical and sexual violence. Column 2 of Table 3.2 shows the association between the experience of physical violence and contraceptive use among the sub-sample of young women interviewed in the Youth Study (IIPS and Population Council, 2010). Column 3 shows the association between the experience of sexual violence at initiation and contraceptive use among all married young women who had started cohabiting drawn from the Youth Study and district level studies from Andhra Pradesh, Madhya Pradesh and Pune. Consolidated findings from the six Youth Study states indicate that the

\section{Table 3.2:}

Association between marital violence experienced by currently married young women and current practice of modern contraception: Findings from various surveys, 2000s

\begin{tabular}{|c|c|c|}
\hline \multirow[t]{2}{*}{ Site } & Physical violence & Sexual violence \\
\hline & Odds ratios & Odds ratios \\
\hline & $\begin{array}{l}\text { Experienced during first } \\
12 \text { months of marriage }\end{array}$ & Experienced at initiation $^{b}$ \\
\hline 6 states $^{1}$ & 1.00 & 0.96 \\
\hline Bihar $^{1}$ & 1.19 & $1.62^{* *}$ \\
\hline Jharkhand $^{1}$ & 1.26 & $1.97^{* * *}$ \\
\hline Rajasthan ${ }^{1}$ & 1.45 & 1.08 \\
\hline Maharashtra $^{1}$ & 1.17 & 1.08 \\
\hline Andhra Pradesh ${ }^{1}$ & 0.81 & 1.00 \\
\hline Tamil Nadu ${ }^{1}$ & 0.75 & 0.95 \\
\hline $\mathrm{AP} / \mathrm{MP}^{2}$ & NA & $0.67^{* * *}$ \\
\hline Pune district ${ }^{3}$ & NA & 0.77 \\
\hline
\end{tabular}

"Among currently married women (aged 15-24) who had cohabited for one year or more.

${ }^{b}$ Among currently married women (aged 15-24).

${ }^{*} p<=0.05 ;{ }^{* *} p<=0.01 ;{ }^{* * *} p<=0.001$.

$A P=$ Andhra Pradesh; $M P=$ Madhya Pradesh; NA: not available, not asked.

Source: ${ }^{1}$ IIPS and Population Council, 2010; ${ }^{2}$ Santhya, Jejeebhoy and Ghosh, 2008; ${ }^{3}$ Alexander et al., 2006. 
experience of violence early in marriage-both physical and sexual—was unrelated with current contraceptive use. Individually too, associations were, for the most part, insignificant, as was the association between sexual violence and contraceptive use as assessed in the Pune district study. Some exceptions were evident. Among Youth Study states, a strong positive association was observed between sexual violence and contraception in Bihar and Jharkhand. In contrast, district level surveys in one district of Andhra Pradesh and two districts of Madhya Pradesh report that forced sex in early married life appears to have a significantly negative association with current contraceptive use.
Evidence from young men is reported in Table 3.3. Findings from the Youth Study suggest that the perpetration of physical and sexual violence early in marriage had a significant positive association with current contraception when all states were considered together. Associations were, however, insignificant, for the most part, when data from each state were analysed separately; the exception was Bihar, in which men who had perpetrated physical violence on their wife were five times more likely than other men to report contraception. Finally, neither the three district survey in Andhra Pradesh and Madhya Pradesh, nor the Pune district study show a significant association between the perpetration of

\section{Table 3.3:}

Association between marital violence perpetrated by currently married young men and current practice of modern contraception: Findings from various surveys, 2000s

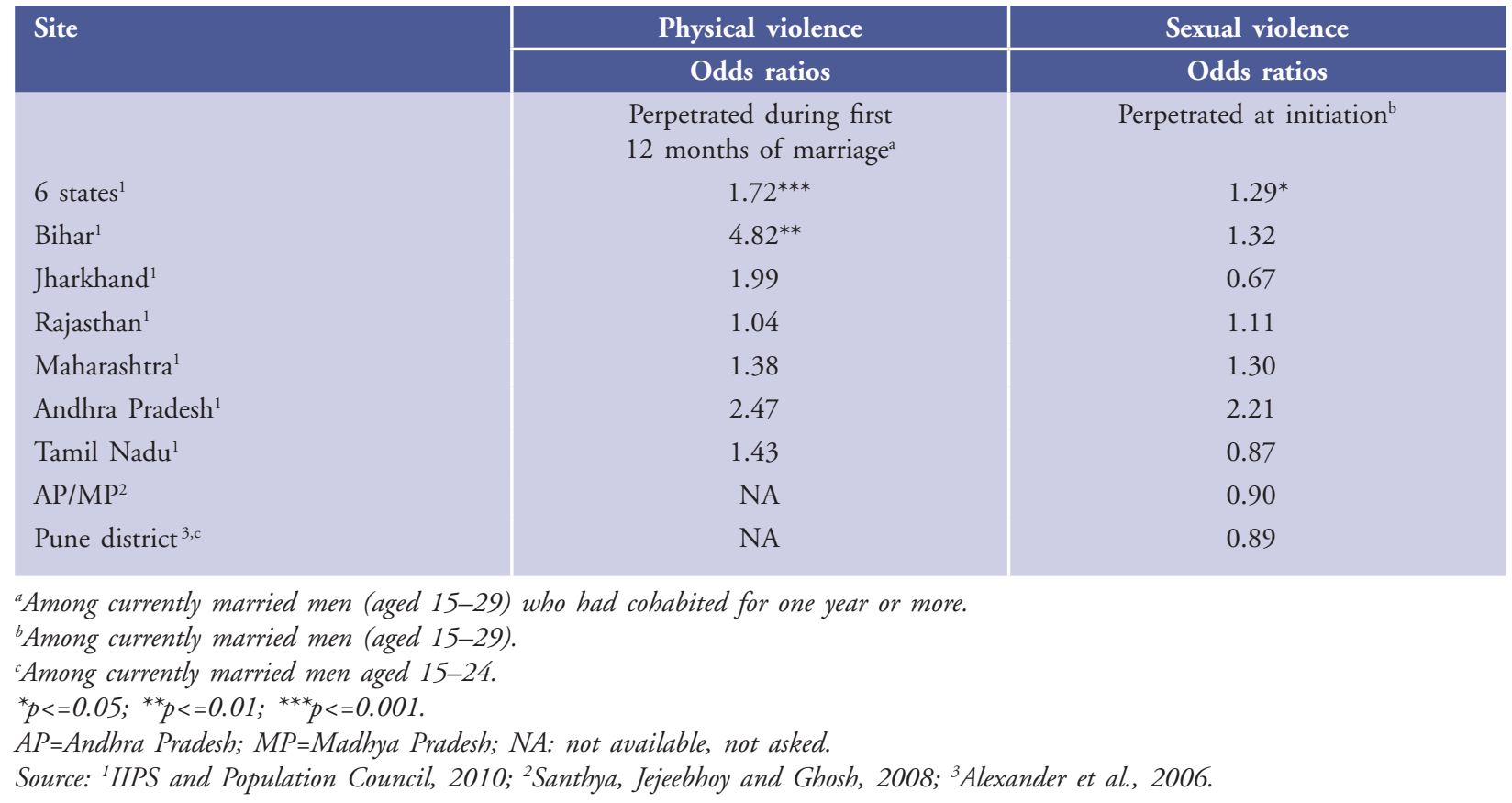


sexual violence early in marriage and the practice of current contraception.

Several explanations have been suggested in the literature for the mixed results observed: it is possible that women who experience violence are more likely than others to want to control future childbearing, resulting in a positive association between the experience of violence and contraception (Hindin, Kishor and Ansara, 2008; Kishor and Johnson, 2004). At the same time, women who experience violence may not adopt contraception for fear of exacerbating violence, thereby resulting in lower prevalence of contraception among those who experience violence (see for example, Stephenson, Koenig and Ahmed, 2006a). We argue that these conflicting motivations may account for the lack of association between the experience of violence and practice of contraception observed among young women. The strong positive association observed between the perpetration of violence and practice of contraception among young men may reflect the same association as suggested for women: that the wives of men who perpetrate violence on their wife may be more likely than others to want to control future childbearing.

\section{Unintended pregnancy and abortion}

Studies in India, summarised in Table 3.4 and Figure 3.1 , consistently show a direct association between marital violence and the experience of unplanned pregnancy, irrespective of the type of data, the measure of unplanned pregnancy or the measure of marital violence used in the analysis, and irrespective of the setting in which the study was conducted.
Using a longitudinal design in which women interviewed at the time of the NFHS-2 survey were re-interviewed 3-4 years later in four states, and relying on a prospectively measured indicator of unwanted pregnancy, that is, any pregnancy during the inter-survey period reported by women who wanted no more children at the earlier survey, Stephenson et al. (2008) found that women who experienced physical violence in the one year preceding the baseline were significantly more likely than those who did not to experience unwanted pregnancy (OR 1.28) during the inter-survey period, even after controlling for parity, presence of a living son, educational attainment levels of women and their husband, decision-making power, household assets and state of residence. The study clearly avoids the many methodological challenges associated with investigations of this relationship with cross-sectional data, including post-birth rationalisation (Koenig et al., 2006) and the difficulty of disentangling temporality issues.

Notwithstanding the limitations of crosssectional studies, a number of studies conducted among married men and women in communitybased settings and among women in facility-based settings have also observed a similar association. For example, a bivariate analysis of NFHS-2 data reports that women who experienced physical violence perpetrated by their husband or in-laws since the age of 15 were more likely than those who did not to report a mistimed or unwanted pregnancy (Singh, Mahapatra and Dutta, 2008). Similarly, a facilitybased study observed that women who experienced physical violence during pregnancy were twice as 
Figure 3.1: Association between marital violence and unwanted pregnancy and abortion

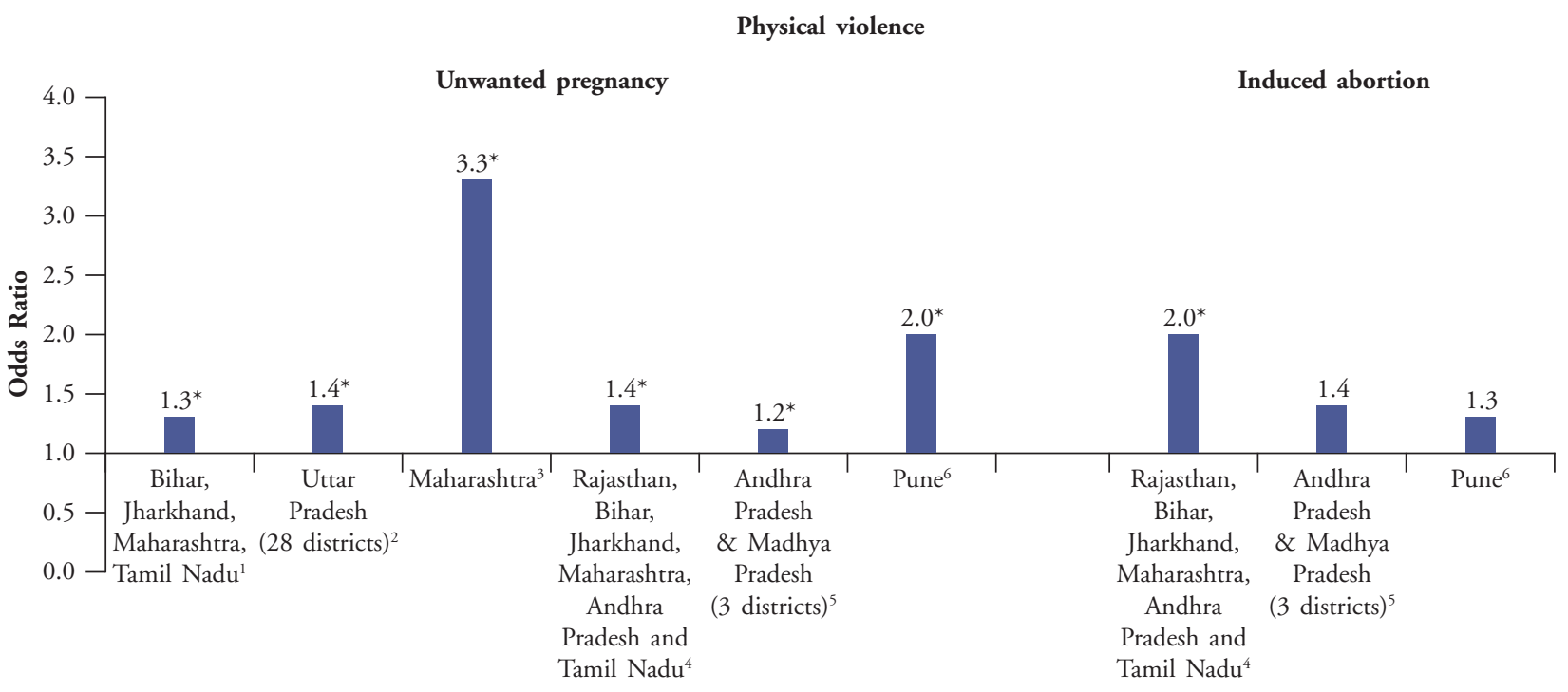

Sexual violence

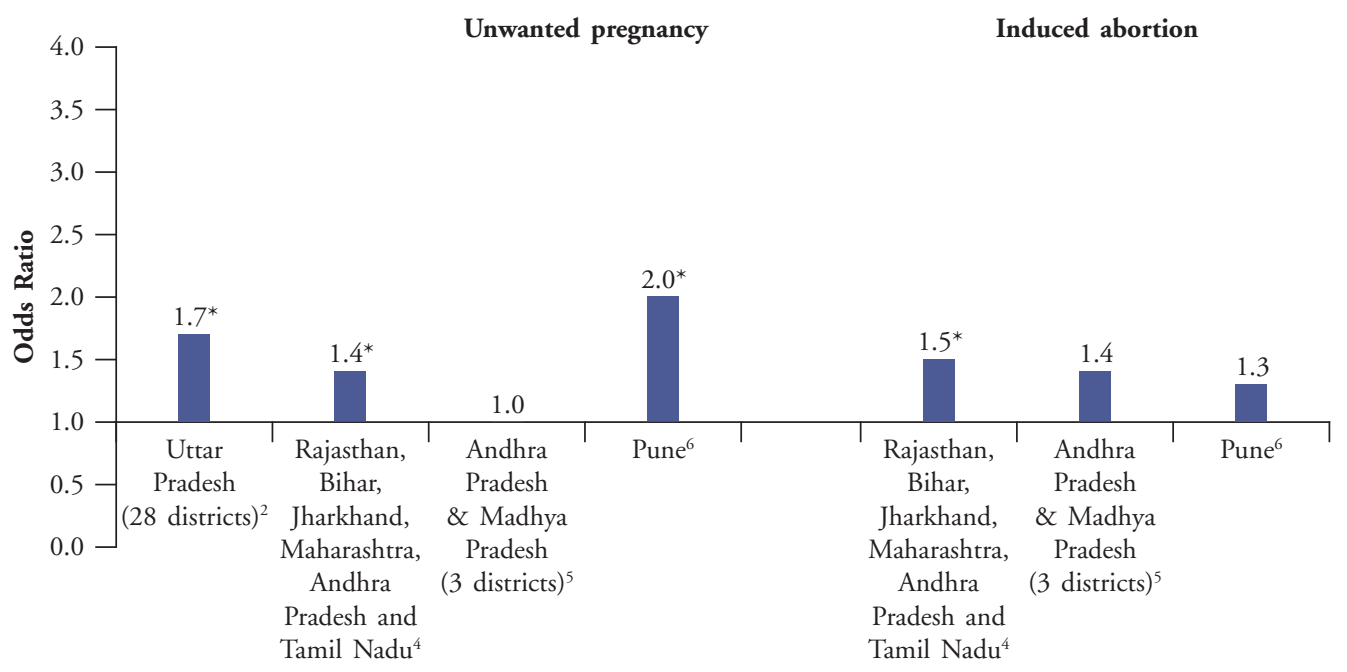

*Statistically significant at 05 level or better, after controlling for the effects of a range of socio-demographic factors.

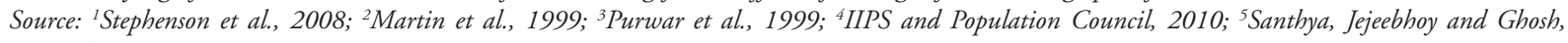
2008; ${ }^{6}$ Alexander et al., 2006. 
Table 3.4:

Association between marital violence and experience of unintended pregnancy and abortion: Findings from various studies, 1990s-2000s

\begin{tabular}{|c|c|c|c|c|c|c|}
\hline Site & $\begin{array}{l}\text { Population } \\
\text { selected }\end{array}$ & $\begin{array}{l}\text { Type of } \\
\text { analysis }\end{array}$ & $\begin{array}{c}\text { Health } \\
\text { outcome } \\
\text { measure used }\end{array}$ & $\begin{array}{c}\text { Violence } \\
\text { measure used }\end{array}$ & $\begin{array}{l}\text { Direction } \\
\text { of } \\
\text { association }\end{array}$ & Source \\
\hline $\begin{array}{l}\text { Bihar, } \\
\text { Jharkhand, } \\
\text { Maharashtra, } \\
\text { Tamil Nadu }\end{array}$ & $\begin{array}{l}\text { Currently married } \\
\text { women aged } \\
15-49 \text { with at } \\
\text { least one child } \\
\text { and not using } \\
\text { contraception } \\
\text { at the time of } \\
\text { NFHS-2 (1998- } \\
\text { 99) and followed } \\
\text { up in 2002-03, } \\
\text { rural, state-wide }\end{array}$ & $\begin{array}{l}\text { Longitudinal, } \\
\text { multivariate }\end{array}$ & $\begin{array}{l}\text { Any pregnancy } \\
\text { during the } \\
\text { inter-survey } \\
\text { period reported } \\
\text { by women who } \\
\text { wanted no } \\
\text { more children } \\
\text { at baseline }\end{array}$ & $\begin{array}{l}\text { Experience of } \\
\text { physical violence } \\
\text { in the } 1 \text { year } \\
\text { preceding the } \\
\text { baseline }\end{array}$ & $(+)$ & $\begin{array}{l}\text { Stephenson et al., } \\
2008\end{array}$ \\
\hline $\begin{array}{l}\text { Maharashtra } \\
\text { (Nagpur) }\end{array}$ & $\begin{array}{l}\text { Currently married } \\
\text { women (age not } \\
\text { specified) seeking } \\
\text { antenatal care } \\
\text { ( } 28-40 \text { weeks } \\
\text { of pregnancy), } \\
\text { secondary and } \\
\text { tertiary hospitals }\end{array}$ & $\begin{array}{l}\text { Cross-sectional, } \\
\text { bivariate }\end{array}$ & $\begin{array}{l}\text { Unwanted } \\
\text { current } \\
\text { pregnancy }\end{array}$ & $\begin{array}{l}\text { Experience of } \\
\text { physical violence } \\
\text { (by husband as } \\
\text { well as others) } \\
\text { during pregnancy }\end{array}$ & $(+)$ & $\begin{array}{l}\text { Purwar et al., } \\
1999\end{array}$ \\
\hline India & $\begin{array}{l}\text { Ever-married } \\
\text { women aged 15-49, } \\
\text { nation-wide }\end{array}$ & $\begin{array}{l}\text { Cross-sectional, } \\
\text { bivariate }\end{array}$ & $\begin{array}{l}\text { Unintended } \\
\text { pregnancy }\end{array}$ & $\begin{array}{l}\text { Experience of } \\
\text { physical violence } \\
\text { perpetrated by } \\
\text { husband or in- } \\
\text { laws since age } 15\end{array}$ & $(+)$ & $\begin{array}{l}\text { Singh, Mahapatra } \\
\text { and Dutta, } 2008\end{array}$ \\
\hline $\begin{array}{l}\text { Tamil Nadu } \\
\text { (Kancheepuram } \\
\text { district, } 98 \\
\text { hamlets) }\end{array}$ & $\begin{array}{l}\text { Ever-married } \\
\text { women aged } 35 \\
\text { years or more who } \\
\text { had completed } \\
\text { childbearing; those } \\
\text { below age } 35 \text { who } \\
\text { had not completed } \\
\text { childbearing }\end{array}$ & Qualitative & Abortion & $\begin{array}{l}\text { Experience of } \\
\text { non-consensual } \\
\text { sex, including } \\
\text { sexual violence }\end{array}$ & $(+)$ & $\begin{array}{l}\text { Ravindran and } \\
\text { Balasubramanian, } \\
2004\end{array}$ \\
\hline $\begin{array}{l}\text { Bihar, } \\
\text { Jharkhand, } \\
\text { Maharashtra, } \\
\text { Tamil Nadu }\end{array}$ & $\begin{array}{l}\text { Currently married } \\
\text { women aged } \\
15-49 \text { with at } \\
\text { least one child and } \\
\text { not sterilised at the } \\
\text { time of NFHS-2 } \\
\text { (1998-99) and } \\
\text { followed up in } \\
\text { 2002-03, rural, } \\
\text { state-wide }\end{array}$ & $\begin{array}{l}\text { Longitudinal, } \\
\text { multivariate }\end{array}$ & $\begin{array}{l}\text { Abortion in } \\
\text { the inter-survey } \\
\text { period }\end{array}$ & $\begin{array}{l}\text { Experience of } \\
\text { physical violence } \\
\text { in the } 1 \text { year } \\
\text { preceding the } \\
\text { baseline }\end{array}$ & $(+)$ & $\begin{array}{l}\text { Stephenson, } \\
\text { Jadhav and } \\
\text { Hindin, } 2010\end{array}$ \\
\hline
\end{tabular}

$(N S)=$ Not significant; $(+)=$ significant positive association, $p<=0.05 ;(-)=$ significant negative association, $p<=0.05$. 
likely as those who did not to report that their last pregnancy was unwanted (Purwar et al., 1999).

The link between men's perpetration of spousal violence and unplanned pregnancy was explored in a community-based study of married men in Uttar Pradesh. Findings demonstrate a positive and systematic association between the perpetration of spousal physical and sexual violence over the course of marital life and men's reports that their wife had experienced one or more unplanned pregnancy, even after a range of socio-demographic factors were controlled (Martin et al., 1999).

As evident from Table 3.5, studies conducted among young women by and large corroborate the finding of a positive association between marital violence and the experience of unplanned pregnancy. Indeed, logistic regression confirms that among young women who had ever been pregnant, those who had experienced physical violence over the course of married life and in the first year of marriage in the Youth Study were significantly more likely than those who had not to have ever experienced unwanted pregnancy (OR 1.37 and 1.33 , respectively). A similar positive association was observed with indicators of sexual violence as well (OR 1.38 and 1.42, respectively). The patterns remained similar in most of the six states when analysed separately (OR 1.5-1.8 [physical violence] and 1.4-2.7 [sexual violence]), as well as in the

\section{Table 3.5:}

Association between marital violence experienced by currently married young women and unwanted last pregnancy: Findings from various surveys, 2000s

\begin{tabular}{|c|c|c|c|c|}
\hline \multirow[t]{2}{*}{ Site } & \multicolumn{2}{|c|}{ Physical violence } & \multicolumn{2}{|c|}{ Sexual violence } \\
\hline & \multicolumn{2}{|c|}{ Odds ratios } & \multicolumn{2}{|c|}{ Odds ratios } \\
\hline & Ever experienced $^{a}$ & $\begin{array}{l}\text { Experienced in first } 12 \\
\text { months of marriage }\end{array}$ & Ever experienced ${ }^{a}$ & $\begin{array}{l}\text { Experienced at } \\
\text { initiation }^{\mathrm{a}}\end{array}$ \\
\hline 6 states $^{1}$ & $1.37^{* * *}$ & $1.33^{* *}$ & $1.38^{* *}$ & $1.42^{* * *}$ \\
\hline Bihar $^{1}$ & 1.35 & 0.95 & 1.06 & 1.11 \\
\hline Jharkhand $^{1}$ & 1.20 & $1.67^{* *}$ & 1.18 & 1.17 \\
\hline Rajasthan $^{1}$ & 1.26 & 1.04 & $1.44^{*}$ & $1.53^{* *}$ \\
\hline Maharashtra ${ }^{1}$ & $1.48^{* * *}$ & $1.77^{* *}$ & 1.14 & 1.04 \\
\hline Andhra Pradesh ${ }^{1}$ & $1.71^{* * *}$ & $1.79^{*}$ & $1.66^{* *}$ & $2.43^{* * *}$ \\
\hline Tamil Nadu ${ }^{1}$ & $1.47^{* *}$ & $1.54^{* *}$ & $1.48^{*}$ & 1.30 \\
\hline $\mathrm{AP} / \mathrm{MP}^{2}$ & $1.24^{+}$ & NA & 0.99 & 0.86 \\
\hline Pune district ${ }^{3}$ & $1.95^{* * *}$ & NA & $2.03^{* *}$ & 1.47 \\
\hline $\begin{array}{l}{ }^{A} \text { Among currently } m \\
{ }^{b} \text { Among currently } m \\
{ }^{*} p<=0.05 ;{ }^{* *} p<=0 . \\
\text { AP }=\text { Andhra Pradesh } \\
\text { Source: }{ }^{1} \text { IIPS and I }\end{array}$ & $\begin{array}{l}\text { n (aged 15-24) } \\
\text { (aged 15-24) } \\
\text { oo1. } \\
\text { hya Pradesh; NA: }\end{array}$ & $\begin{array}{l}\text { d ever experienced a } p \\
\text { d cohabited for one ye } \\
\text { ailable, not asked. }\end{array}$ & zore and who had & enced a pregn \\
\hline
\end{tabular}


study in Pune district (OR 1.95 [physical violence] and 2.03 [sexual violence]), and in the case of experience of physical (but not sexual) violence in the three district study in Andhra Pradesh and Madhya Pradesh (OR 1.24).

Compared to the association between marital violence and unintended pregnancy, the link between marital violence and abortion has been far less studied in India. Indeed, an extensive search located only two studies that explored these associations. The first used qualitative methodologies to assess the association between non-consensual sex and induced abortion among ever-married women aged 35 years or more who had completed childbearing, and those aged below 35 years who had not completed childbearing (Table 3.4). The study found that non-consensual sex, including sexual violence, was more common among women who had sought an abortion than among those who had not (Ravindran and Balasubramanian, 2004). The second was a longitudinal study that explored this association, using data from the NFHS-2 (1998-99) and the follow-up survey of women in four states (Bihar, Jharkhand, Maharashtra and Tamil Nadu) described earlier. Analysis was conducted among a sample of 4,025 women who were interviewed at the time of the NFHS-2 survey, and who were not sterilised at the time. Findings show that women who experienced physical violence in the 12 months preceding the NFHS-2 were significantly more likely than those who did not to have experienced an abortion in the intervening period, even after socio-demographic factors were controlled (Relative Risk Ratio (RRR) 2.13) (Stephenson, Jadhav and Hindin, 2010).
Evidence from studies of youth, reported in Tables 3.6 and 3.7, shows mixed results. Among young women who had ever been pregnant (Table 3.6), the Youth Study finds, for example, a significant positive association between the experience of physical and sexual violence, respectively, at any time within marriage and the experience of induced abortion. Indeed, those who had ever experienced physical violence were twice as likely, and those who had ever experienced sexual violence 1.5 times as likely, as others to have had an induced abortion. Those who had experienced physical violence in the early years of marriage were almost twice as likely as other women (1.8 times), moreover, to have undergone an induced abortion; experience of sexual violence at initiation was not, however, significantly associated with abortion experiences. Findings from individual states were less consistent: while 4 of the 6 states reported a significant positive association between the experience of physical violence over the course of married life and the experience of induced abortion, just 1-2 states showed a significant association when other measures of violence were used. Findings from the three district study in Andhra Pradesh and Madhya Pradesh and the Pune district study suggest no significant association between the experience of physical or sexual violence within marriage and the experience of induced abortion.

Evidence from young men, presented in Table 3.7 , is fairly similar. Young men who perpetrated physical violence on their wife at any time in marriage were significantly_almost three times-more likely than other men to report that 


\section{Table 3.6:}

Association between marital violence experienced by currently married young women and experience of abortion: Findings from various surveys, 2000s

\begin{tabular}{|c|c|c|c|c|}
\hline \multirow[t]{3}{*}{ Site } & \multicolumn{2}{|c|}{ Physical violence } & \multicolumn{2}{|c|}{ Sexual violence } \\
\hline & \multicolumn{2}{|c|}{ Odds ratios } & \multicolumn{2}{|c|}{ Odds ratios } \\
\hline & Ever experienced ${ }^{\mathrm{a}}$ & $\begin{array}{c}\text { Experienced in first } \\
12 \text { months of marriage }\end{array}$ & Ever experienced ${ }^{\mathrm{a}}$ & $\begin{array}{l}\text { Experienced at } \\
\text { initiation }^{\mathrm{a}}\end{array}$ \\
\hline 6 states $^{1}$ & $1.98^{* * *}$ & $1.84^{* *}$ & $1.52^{* *}$ & 1.37 \\
\hline Bihar $^{1}$ & 0.93 & $\mathrm{NC}$ & 1.49 & 1.78 \\
\hline Jharkhand $^{1}$ & $2.68^{* *}$ & $3.68^{* * *}$ & $2.16^{*}$ & 1.89 \\
\hline Rajasthan $^{1}$ & $0.17^{* *}$ & 0.32 & 2.10 & 1.32 \\
\hline Maharashtra $^{1}$ & $2.39^{* *}$ & $2.50^{* *}$ & 1.20 & 1.30 \\
\hline Andhra Pradesh ${ }^{1}$ & $2.82^{*}$ & 1.35 & $3.19^{*}$ & $3.93^{*}$ \\
\hline Tamil Nadu ${ }^{1}$ & $2.01^{* *}$ & 1.14 & 1.21 & 0.80 \\
\hline $\mathrm{AP} / \mathrm{MP}^{2}$ & 1.42 & NA & 1.41 & 1.31 \\
\hline Pune district ${ }^{3}$ & 1.34 & NA & 1.27 & 0.89 \\
\hline
\end{tabular}

among currently married women (aged 15-24) who had ever experienced a pregnancy.

${ }^{b}$ Among currently married women (aged 15-24) who had cohabited for one year or more and who had ever experienced a pregnancy. ${ }^{*} p<=0.05 ;{ }^{* *} p<=0.01 ;{ }^{* * *} p<=0.001$.

AP=Andhra Pradesh; MP=Madhya Pradesh; NA: not available, not asked; NC: Could not be calculated as abortion was not reported among those who reported violence.

Source: 'IIPS and Population Council, 2010; ${ }^{2}$ Santhya, Jejeebhoy and Ghosh, 2008; ${ }^{3}$ Alexander et al., 2006.

\section{Table 3.7:}

Association between marital violence perpetrated by currently married young men and experience of abortion: Findings from various surveys, 2000s

\begin{tabular}{|c|c|c|c|c|}
\hline \multirow[t]{3}{*}{ Site } & \multicolumn{2}{|c|}{ Physical violence } & \multicolumn{2}{|c|}{ Sexual violence } \\
\hline & \multicolumn{2}{|c|}{ Odds ratios } & \multicolumn{2}{|c|}{ Odds ratios } \\
\hline & Ever perpetrated $^{\mathrm{a}}$ & $\begin{array}{c}\text { Perpetrated in first } \\
12 \text { months of marriage }\end{array}$ & Ever perpetrated ${ }^{a}$ & $\begin{array}{l}\text { Perpetrated at } \\
\text { initiation }^{\mathrm{a}}\end{array}$ \\
\hline 6 states $^{1, c}$ & $2.78^{* *}$ & 2.06 & 1.71 & 1.23 \\
\hline $\mathrm{AP} / \mathrm{MP}^{2}$ & 1.11 & NA & 1.47 & 0.92 \\
\hline Pune district ${ }^{3, d}$ & 1.29 & NA & 1.46 & 2.58 \\
\hline
\end{tabular}

"Among currently married men (aged 15-29) whose wife had ever experienced a pregnancy.

${ }^{b}$ Among men (aged 15-29) who had cohabited for one year or more and whose wife had ever experienced a pregnancy.

'Too few cases in each state to conduct a state-wise analysis.

${ }^{d}$ Among currently married men (aged 15-24) whose wife had ever experienced a pregnancy.

${ }^{*} p<=0.05 ;{ }^{* *} p<=0.01 ;{ }^{* * *} p<=0.001$.

$A P=$ Andhra Pradesh; $M P=$ Madhya Pradesh; NA: not available, not asked.

Source: ${ }^{1}$ IIPS and Population Council, 2010; ${ }^{2}$ Santhya, Jejeebhoy and Ghosh, 2008; ${ }^{3}$ Alexander et al., 2006. 
their wife had experienced an induced abortion. In contrast, there is no evidence of an association with other measures of perpetration of physical or sexual violence; likewise, associations were generally insignificant in both the three district study in Andhra Pradesh and Madhya Pradesh and the Pune district study.

Clearly, the exact pathways through which the associations between indicators of marital violence and unwanted pregnancy and induced abortion, respectively occur need further study. However, a primary explanation appears to lie in the constraining effect of violence on a woman's ability to negotiate or effectively practise contraception with her partner. For example, a study of women in Uttar Pradesh who had recently undergone an abortion found that many of these women felt they had little control over reproductive decisions and that the threat of physical violence resulted in their nonuse of contraception and experience of unwanted pregnancy (Khan et al., 1996).

\section{Reproductive tract infection, sexually transmitted infection and HIV}

A number of studies in India, reported in Table 3.8, have explored the association between marital violence and women's experience of RTI/STI/ HIV. While all these studies used community-based samples, they differed considerably in terms of methodology. Most relied on cross-sectional data; however, a few used longitudinal data. Some studies measured prevalence of infection based on women's self-reports of symptoms experienced, while others used laboratory diagnosis. Moreover, while most reported prevalence of infection, a few reported incidence of infection.

Studies that relied on women's self-reports of symptoms of RTI and gynaecological morbidity present a mixed picture (Table 3.8 and Figure 3.2). For example, a population-based longitudinal study of women's health in Goa that interviewed women at recruitment, and then 6 and 12 months thereafter, explored the links between spousal violence (sexual and physical, lifetime and recent) and women's reports of abnormal vaginal discharge, dysuria, non-menstrual lower abdominal pain, dyspareunia and dysmenorrhoea, using both cross-sectional and longitudinal data (Chowdhary and Patel, 2008). The cross-sectional analysis found, after adjusting for age, household economic status and literacy level, a positive association between (a) experience of physical violence over the course of married life and dysuria and dyspareunia; (b) experience of sexual violence over the course of married life and nonmenstrual lower abdominal pain, abnormal vaginal discharge and dyspareunia; (c) recent experience of physical violence and dyspareunia; and (d) recent experience of sexual violence and non-menstrual lower abdominal pain and dyspareunia. In the longitudinal analysis, however, spousal violence experienced at baseline significantly increased the risk of dysuria and STI; while dysuria was associated only with lifetime physical violence, STI was associated only with sexual violence, both lifetime and recent.

Analyses of NFHS-2 data from a number of states have established a direct association between marital violence and women's reports of symptoms of RTI and other gynaecological morbidity. For 
example, an analysis of data pertaining to Bihar and Tamil Nadu explored the association between women's experience of physical violence within marriage and their reported reproductive morbidities operationalised as an index ranging from 0 to 3 that summed self-reported symptoms of RTI, STI and sexual intercourse-related problems; a significant and positive association between the experience of violence and this measure of self-reported problems was observed in both states, after controlling for a range of socio-demographic factors (Audinarayana, 2005). Likewise, another study that examined the association between women's experience of physical violence since the age of 15 (largely, but not entirely, perpetrated by the husband) and reported symptoms of RTI, using NFHS-2 data from Kerala, found that women who had ever experienced violence were almost twice as likely as those who had not to report RTI symptoms, even after controlling for a host of socio-demographic factors and indicators of female agency (OR 1.9) (Sudha, Morrison and Zhu, 2007).

A study in Uttar Pradesh, using data from married women aged 15-45 and their husbands, examined the association between women's reports of symptoms of gynaecological morbidity among women who had a birth in the three years prior to the survey and their husband's reports of the perpetration of violence (physical or sexual) in the 12 months prior to the interview. This study, like those reported above, shows that compared to women whose husband reported no violence,

Figure 3.2: Association between marital violence and experience of symptoms of RTI/STI

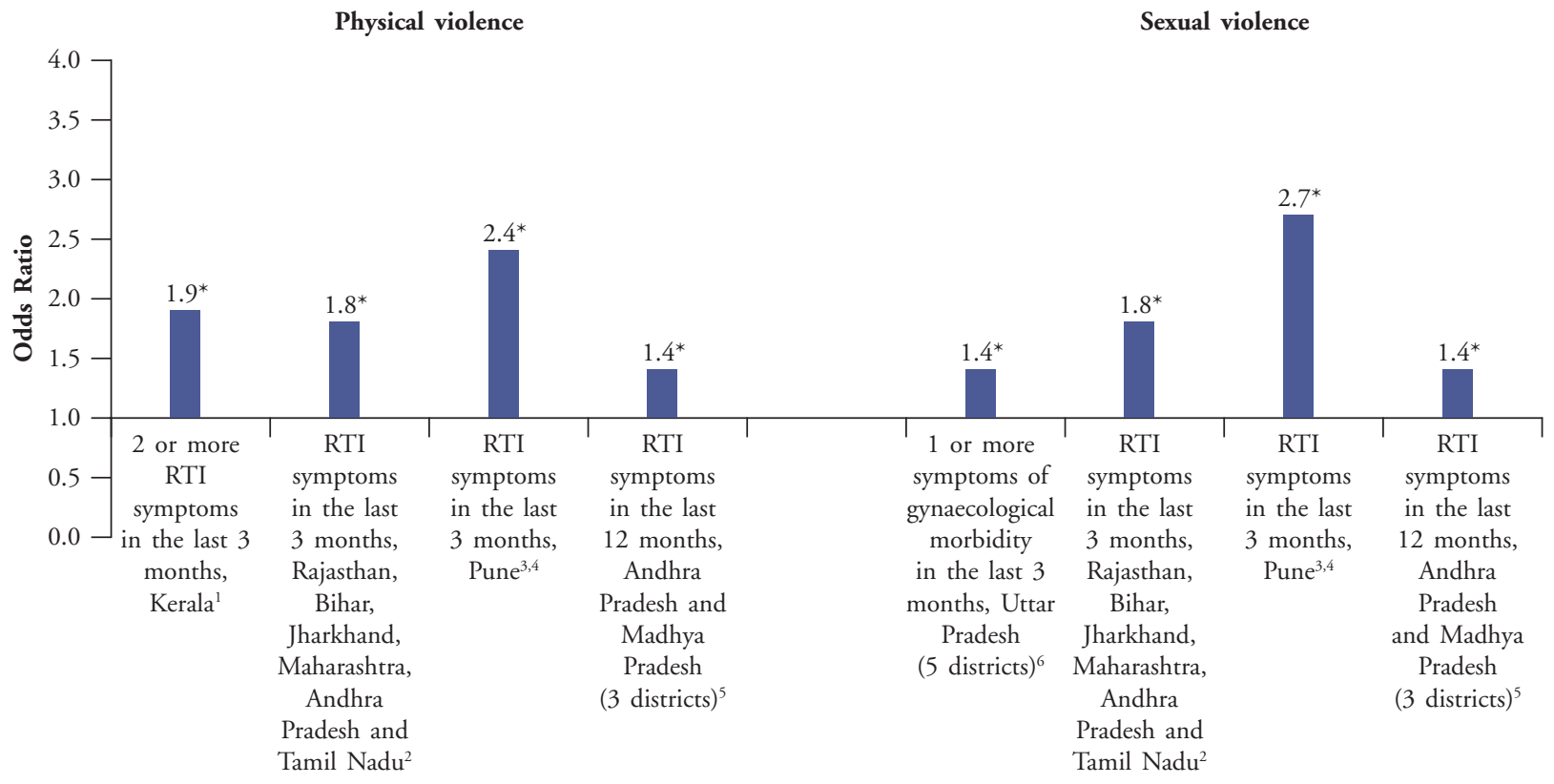

*Statistically significant at .05 level or better, after controlling for the effects of a range of socio-demographic factors.

Source: ${ }^{1}$ Sudha, Morrison and Zhu, 2007; ${ }^{2}$ IIPS and Population Council, 2010; ${ }^{3}$ Alexander et al., 2006; ${ }^{4}$ Acharya and Jejeebhoy, 2008; ${ }^{5}$ Santhya, Jejeebhoy and Ghosh, 2008; 'Stephenson, Koenig and Ahmed, 2006. 


\section{Table 3.8:}

Association between marital violence and experience of symptoms of RTI/STI/HIV: Findings from various studies, 2000s

\begin{tabular}{|c|c|c|c|c|c|c|}
\hline Site & Population selected & $\begin{array}{l}\text { Type of } \\
\text { analysis }\end{array}$ & $\begin{array}{l}\text { Health outcome } \\
\text { measure used }\end{array}$ & $\begin{array}{c}\text { Violence measure } \\
\text { used }\end{array}$ & $\begin{array}{l}\text { Direction of } \\
\text { association }\end{array}$ & Source \\
\hline $\begin{array}{l}\text { Goa } \\
\text { (Aldona) }\end{array}$ & $\begin{array}{l}\text { Currently married } \\
\text { women aged } 18-50 \\
\text { residing in rural } \\
\text { areas served by a } \\
\text { primary health centre } \\
\text { (unmarried women } \\
\text { included in the study } \\
\text { but excluded from this } \\
\text { analysis) }\end{array}$ & $\begin{array}{l}\text { Cross- } \\
\text { sectional, } \\
\text { multivariate }\end{array}$ & $\begin{array}{l}\text { Self-reported } \\
\text { abnormal vaginal } \\
\text { discharge in the } 3 \\
\text { months preceding } \\
\text { the interview } \\
\text { Self-reported dysuria } \\
\text { in the } 3 \text { months } \\
\text { preceding the } \\
\text { interview }\end{array}$ & $\begin{array}{l}\text { Experience of } \\
\text { physical violence } \\
\text { ever } \\
\text { Experience of } \\
\text { physical violence } \\
\text { in the } 3 \text { months } \\
\text { preceding the } \\
\text { interview } \\
\text { Experience of } \\
\text { sexual violence ever } \\
\text { Experience of } \\
\text { sexual violence } \\
\text { in the } 3 \text { months } \\
\text { preceding the } \\
\text { interview } \\
\text { Experience of } \\
\text { physical violence } \\
\text { ever } \\
\text { Experience of } \\
\text { physical violence } \\
\text { in the } 3 \text { months } \\
\text { preceding the } \\
\text { interview } \\
\text { Experience of } \\
\text { sexual violence ever } \\
\text { Experience of } \\
\text { sexual violence } \\
\text { in the } 3 \text { months } \\
\text { preceding the } \\
\text { interview }\end{array}$ & $\begin{array}{l}\text { (NS) } \\
(\mathrm{NS}) \\
(+) \\
(\mathrm{NS}) \\
(+) \\
(\mathrm{NS}) \\
(\mathrm{NS}) \\
\end{array}$ & $\begin{array}{l}\text { Chowdhary } \\
\text { and Patel, } \\
2008\end{array}$ \\
\hline
\end{tabular}


Table 3.8: (Cont'd)

\begin{tabular}{|c|c|c|c|c|c|c|}
\hline Site & Population selected & $\begin{array}{l}\text { Type of } \\
\text { analysis }\end{array}$ & $\begin{array}{l}\text { Health outcome } \\
\text { measure used }\end{array}$ & $\begin{array}{c}\text { Violence measure } \\
\text { used }\end{array}$ & $\begin{array}{l}\text { Direction of } \\
\text { association }\end{array}$ & Source \\
\hline & & & $\begin{array}{l}\text { Self-reported non- } \\
\text { menstrual lower } \\
\text { abdominal pain } \\
\text { in the } 3 \text { months } \\
\text { preceding the } \\
\text { interview } \\
\text { Self-reported } \\
\text { dyspareunia in the } \\
3 \text { months preceding } \\
\text { the interview }\end{array}$ & $\begin{array}{l}\text { Experience of } \\
\text { physical violence } \\
\text { ever } \\
\text { Experience of } \\
\text { physical violence } \\
\text { in the } 3 \text { months } \\
\text { preceding the } \\
\text { interview } \\
\text { Experience of } \\
\text { sexual violence ever } \\
\text { Experience of } \\
\text { sexual violence } \\
\text { in the } 3 \text { months } \\
\text { preceding the } \\
\text { interview } \\
\text { Experience of } \\
\text { physical violence } \\
\text { ever } \\
\text { Experience of } \\
\text { physical violence } \\
\text { in the } 3 \text { months } \\
\text { preceding the } \\
\text { interview } \\
\text { Experience of } \\
\text { sexual violence ever } \\
\text { Experience of } \\
\text { sexual violence } \\
\text { in the } 3 \text { months } \\
\text { preceding the } \\
\text { interview } \\
\text { Experience of } \\
\text { physical violence } \\
\text { ever } \\
\text { Experience of } \\
\text { physical violence } \\
\text { in the } 3 \text { months } \\
\text { preceding the } \\
\text { interview } \\
\text { Experience of } \\
\text { sexual violence ever } \\
\text { Experience of } \\
\text { sexual violence } \\
\text { in the } 3 \text { months } \\
\text { preceding the } \\
\text { interview }\end{array}$ & $\begin{array}{l}(+) \\
(+) \\
(+) \\
(+) \\
(\mathrm{NS}) \\
(\mathrm{NS}) \\
(+) \\
\end{array}$ & \\
\hline
\end{tabular}


Table 3.8: (Cont'd)

\begin{tabular}{|c|c|c|c|c|c|c|}
\hline Site & Population selected & $\begin{array}{l}\text { Type of } \\
\text { analysis }\end{array}$ & $\begin{array}{l}\text { Health outcome } \\
\text { measure used }\end{array}$ & $\begin{array}{c}\text { Violence measure } \\
\text { used }\end{array}$ & $\begin{array}{l}\text { Direction of } \\
\text { association }\end{array}$ & Source \\
\hline & $\begin{array}{l}\text { Longitudinal, } \\
\text { multivariate }\end{array}$ & & $\begin{array}{l}\text { STI prevalence } \\
\text { (chlamydia, } \\
\text { gonorrhoea or } \\
\text { trichomoniasis) } \\
\text { Self-reported } \\
\text { abnormal vaginal } \\
\text { discharge during the } \\
\text { inter-survey period }\end{array}$ & $\begin{array}{l}\text { Experience of } \\
\text { physical violence } \\
\text { ever } \\
\text { Experience of } \\
\text { physical violence } \\
\text { in the } 3 \text { months } \\
\text { preceding the } \\
\text { interview } \\
\text { Experience of } \\
\text { sexual violence ever } \\
\text { Experience of } \\
\text { sexual violence } \\
\text { in the } 3 \text { months } \\
\text { preceding the } \\
\text { interview } \\
\text { Experience of } \\
\text { physical violence } \\
\text { ever } \\
\text { Experience of } \\
\text { physical violence } \\
\text { in the } 3 \text { months } \\
\text { preceding the } \\
\text { interview } \\
\text { Experience of } \\
\text { sexual violence ever } \\
\text { Experience of } \\
\text { sexual violence } \\
\text { in the } 3 \text { months } \\
\text { preceding the } \\
\text { interview } \\
\text { Experience of } \\
\text { physical violence } \\
\text { ever } \\
\text { Experience of } \\
\text { physical violence } \\
\text { in the } 3 \text { months } \\
\text { preceding the } \\
\text { interview } \\
\text { Experience of } \\
\text { sexual violence ever } \\
\text { Experience of } \\
\text { sexual violence } \\
\text { in the } 3 \text { months } \\
\text { preceding the } \\
\text { interview }\end{array}$ & $\begin{array}{l}\text { (NS) } \\
\text { (NS) } \\
\text { (NS) } \\
\text { (NS) } \\
\text { (NS) } \\
\text { (NS) } \\
\text { (NS) } \\
(+) \\
\text { (NS) }\end{array}$ & \\
\hline
\end{tabular}


Table 3.8: (Cont'd)

\begin{tabular}{|c|c|c|c|c|c|c|}
\hline Site & Population selected & $\begin{array}{l}\text { Type of } \\
\text { analysis }\end{array}$ & $\begin{array}{l}\text { Health outcome } \\
\text { measure used }\end{array}$ & $\begin{array}{c}\text { Violence measure } \\
\text { used }\end{array}$ & $\begin{array}{l}\text { Direction of } \\
\text { association }\end{array}$ & Source \\
\hline & & & $\begin{array}{l}\text { Self-reported non- } \\
\text { menstrual lower } \\
\text { abdominal pain } \\
\text { during the inter- } \\
\text { survey period } \\
\text { Self-reported } \\
\text { dyspareunia during } \\
\text { the inter-survey } \\
\text { period }\end{array}$ & $\begin{array}{l}\text { Experience of } \\
\text { physical violence } \\
\text { ever } \\
\text { Experience of } \\
\text { physical violence } \\
\text { in the } 3 \text { months } \\
\text { preceding the } \\
\text { interview } \\
\text { Experience of } \\
\text { sexual violence ever } \\
\text { Experience of } \\
\text { sexual violence } \\
\text { in the } 3 \text { months } \\
\text { preceding the } \\
\text { interview } \\
\text { Experience of } \\
\text { physical violence } \\
\text { ever } \\
\text { Experience of } \\
\text { physical violence } \\
\text { in the } 3 \text { months } \\
\text { preceding the } \\
\text { interview } \\
\text { Experience of } \\
\text { sexual violence ever } \\
\text { Experience of } \\
\text { sexual violence } \\
\text { in the } 3 \text { months } \\
\text { preceding the } \\
\text { interview } \\
\text { Experience of } \\
\text { physical violence } \\
\text { ever } \\
\text { Experience of } \\
\text { physical violence } \\
\text { in the } 3 \text { months } \\
\text { preceding the } \\
\text { interview } \\
\text { Experience of } \\
\text { sexual violence ever } \\
\text { Experience of } \\
\text { sexual violence } \\
\text { in the } 3 \text { months } \\
\text { preceding the } \\
\text { interview }\end{array}$ & $\begin{array}{l}\text { (NS) } \\
\text { (NS) } \\
\text { (NS) } \\
(\mathrm{NS}) \\
(+\mathrm{NS}) \\
(+) \\
(\mathrm{NSS}) \\
(\mathrm{NS}) \\
\\
(+)\end{array}$ & \\
\hline
\end{tabular}


Table 3.8: (Cont'd)

\begin{tabular}{|c|c|c|c|c|c|c|}
\hline Site & Population selected & $\begin{array}{l}\text { Type of } \\
\text { analysis }\end{array}$ & $\begin{array}{l}\text { Health outcome } \\
\text { measure used }\end{array}$ & $\begin{array}{c}\text { Violence measure } \\
\text { used }\end{array}$ & $\begin{array}{l}\text { Direction of } \\
\text { association }\end{array}$ & Source \\
\hline $\begin{array}{l}\text { Bihar } \\
\text { and } \\
\text { Tamil } \\
\text { Nadu }\end{array}$ & $\begin{array}{l}\text { Currently married } \\
\text { women aged } 15-49 \text {, } \\
\text { state-wide }\end{array}$ & $\begin{array}{l}\text { Cross- } \\
\text { sectional, } \\
\text { multivariate }\end{array}$ & $\begin{array}{l}\text { Index of } \\
\text { reproductive } \\
\text { morbidity (self- } \\
\text { reported symptoms } \\
\text { of RTI/STI and } \\
\text { sexual intercourse- } \\
\text { related problems) }\end{array}$ & $\begin{array}{l}\text { Experience of } \\
\text { physical violence } \\
\text { ever (by husband as } \\
\text { well as others) }\end{array}$ & $(+)$ & $\begin{array}{l}\text { Audinarayana, } \\
2005\end{array}$ \\
\hline Kerala & $\begin{array}{l}\text { Ever-married women } \\
\text { of reproductive age, } \\
\text { rural and urban, state- } \\
\text { wide }\end{array}$ & $\begin{array}{l}\text { Cross- } \\
\text { sectional, } \\
\text { multivariate }\end{array}$ & $\begin{array}{l}\text { Self-reports of } \\
2 \text { or more RTI } \\
\text { symptoms in the } 3 \\
\text { months preceding } \\
\text { the interview }\end{array}$ & $\begin{array}{l}\text { Experience of } \\
\text { physical violence } \\
\text { (by husband as well } \\
\text { as others) since } \\
\text { age } 15\end{array}$ & $(+)$ & $\begin{array}{l}\text { Sudha, } \\
\text { Morrison and } \\
\text { Zhu, } 2007\end{array}$ \\
\hline $\begin{array}{l}\text { Uttar } \\
\text { Pradesh } \\
(5 \\
\text { districts) }\end{array}$ & $\begin{array}{l}\text { Currently married } \\
\text { women aged } 15-45 \\
\text { who had given } \\
\text { birth in the } 3 \text { years } \\
\text { preceding the survey } \\
\text { and their husband }\end{array}$ & $\begin{array}{l}\text { Cross- } \\
\text { sectional, } \\
\text { multivariate }\end{array}$ & $\begin{array}{l}\text { Self-reports of at } \\
\text { least } 1 \text { symptom } \\
\text { of gynaecological } \\
\text { morbidity in the } 3 \\
\text { months preceding } \\
\text { the survey }\end{array}$ & $\begin{array}{l}\text { Experience of } \\
\text { physical violence } \\
\text { in the } 12 \text { months } \\
\text { preceding the } \\
\text { interview } \\
\text { Experience of } \\
\text { sexual violence in } \\
\text { the } 12 \text { months } \\
\text { preceding the } \\
\text { interview } \\
\text { Experience of } \\
\text { physical and sexual } \\
\text { violence in the } 12 \\
\text { months preceding } \\
\text { the interview }\end{array}$ & (NS) & $\begin{array}{l}\text { Stephenson, } \\
\text { Koenig and } \\
\text { Ahmed, 2006b }\end{array}$ \\
\hline \multirow[t]{2}{*}{$\begin{array}{l}\text { Goa } \\
\text { (Aldona) }\end{array}$} & \multirow[t]{2}{*}{$\begin{array}{l}\text { Currently married } \\
\text { women aged } 18-45 \\
\text { residing in rural } \\
\text { areas served by a } \\
\text { primary health centre } \\
\text { (unmarried women } \\
\text { included in the study } \\
\text { but excluded from this } \\
\text { analysis) }\end{array}$} & \multirow[t]{2}{*}{$\begin{array}{l}\text { Cross- } \\
\text { sectional, } \\
\text { multivariate }\end{array}$} & $\begin{array}{l}\text { STI prevalence } \\
\text { (chlamydia, } \\
\text { gonorrhoea or } \\
\text { trichomoniasis) }\end{array}$ & $\begin{array}{l}\text { Experience of } \\
\text { physical violence } \\
\text { ever }\end{array}$ & (NS) & $\begin{array}{l}\text { Patel et al., } \\
2006\end{array}$ \\
\hline & & & $\begin{array}{l}\text { Endogenous RTI } \\
\text { prevalence (bacterial } \\
\text { vaginosis) }\end{array}$ & $\begin{array}{l}\text { Experience of } \\
\text { physical violence } \\
\text { ever } \\
\text { Experience of } \\
\text { sexual violence ever }\end{array}$ & $(+)$ & \\
\hline
\end{tabular}


Table 3.8: (Cont'd)

\begin{tabular}{|c|c|c|c|c|c|c|}
\hline Site & Population selected & $\begin{array}{l}\text { Type of } \\
\text { analysis }\end{array}$ & $\begin{array}{l}\text { Health outcome } \\
\text { measure used }\end{array}$ & $\begin{array}{c}\text { Violence measure } \\
\text { used }\end{array}$ & $\begin{array}{l}\text { Direction of } \\
\text { association }\end{array}$ & Source \\
\hline $\begin{array}{l}\text { Goa } \\
\text { (Aldona) }\end{array}$ & $\begin{array}{l}\text { Currently married } \\
\text { women aged } 18-45 \\
\text { residing in rural } \\
\text { areas served by a } \\
\text { primary health centre } \\
\text { (unmarried women } \\
\text { included in the study } \\
\text { but excluded from this } \\
\text { analysis) }\end{array}$ & Longitudinal & $\begin{array}{l}\text { STI incidence } \\
\text { (chlamydia, } \\
\text { gonorrhoea or } \\
\text { trichomoniasis) }\end{array}$ & $\begin{array}{l}\text { Experience of } \\
\text { sexual violence ever }\end{array}$ & $(+)$ & $\begin{array}{l}\text { Weiss et al., } \\
2008\end{array}$ \\
\hline India & $\begin{array}{l}\text { Currently married } \\
\text { women aged } 15-49 \\
\text { for whom HIV test } \\
\text { results and data on } \\
\text { exposure to violence } \\
\text { were available, nation- } \\
\text { wide }\end{array}$ & $\begin{array}{l}\text { Cross- } \\
\text { sectional, } \\
\text { multivariate }\end{array}$ & HIV infection & $\begin{array}{l}\text { Experience of } \\
\text { physical violence } \\
\text { ever } \\
\text { Experience of } \\
\text { physical and sexual } \\
\text { violence ever }\end{array}$ & $(+)$ & $\begin{array}{l}\text { Silverman et } \\
\text { al., } 2008\end{array}$ \\
\hline India & $\begin{array}{l}\text { Currently married } \\
\text { women aged } 15-49 \\
\text { for whom HIV test } \\
\text { results were available } \\
\text { for themselves and } \\
\text { their husband, and } \\
\text { data on exposure to } \\
\text { violence were available, } \\
\text { nation-wide }\end{array}$ & $\begin{array}{l}\text { Cross- } \\
\text { sectional, } \\
\text { multivariate }\end{array}$ & HIV infection & $\begin{array}{l}\text { Experience of } \\
\text { physical or sexual } \\
\text { violence ever }\end{array}$ & $(+)$ & $\begin{array}{l}\text { Decker et al. } \\
2009\end{array}$ \\
\hline
\end{tabular}

${ }^{a}$ Women's experience of physical and/or sexual violence was measured by the husband's reports of perpetration of marital violence. $(N S)=$ Not significant $(+)=$ significant positive association, $p<=0.05 ;(-)=$ significant negative association, $p<=0.05$.

women whose husband reported sexual violence only and those whose husband reported both physical and sexual violence had significantly higher odds of reporting symptoms of gynaecologic morbidity (OR 1.4 and 1.7, respectively), even after adjusting for socio-demographic and such reproductive health indicators as contraceptive practice at the time of interview, husband's reported extramarital sex, and woman's prior obstetric complications (Stephenson, Koenig and Ahmed, 2006b).

The limitations of self-reported morbidity are widely recognised. A few studies overcame this limitation by examining the links between marital violence and laboratory-detected prevalence or incidence of RTI/STI. Findings from these studies (Table 3.8 and Figure 3.3) also depict a mixed picture, especially in relation to the experience of STI, depending on the type of data used. For example, using cross-sectional data in a study from Goa, authors note that after controlling for a host of socio-demographic factors, physical and sexual violence over the course of married life was significantly associated with endogenous infections, namely bacterial vaginosis, but not with STI. Indeed, 
those who had experienced physical and sexual violence were 1.7 and 1.9 times, respectively, more likely to have bacterial vaginosis than were those who had no such experiences (Patel et al., 2006). It is not entirely clear why the experience of violence is associated with an endogenous infection such as bacterial vaginosis, but authors suggest that it may reflect the lack of control women have over their hygiene and the possible effects of stress on vaginal flora. Using longitudinal data from the same study obtained by re-interviewing the participants 6 and 12 months later, however, authors observe that sexual violence, both lifetime and recent, was directly associated with the incidence of STI (Chowdhary and Patel, 2008; Weiss et al., 2008).

Growing evidence suggests that violence against women increases their vulnerability to HIV infection as well. An analysis of data from the 2005-06 NFHS-3 of 28,139 currently married, sexually experienced women who had been interviewed with regard to intimate partner violence and tested for HIV found that the prevalence of HIV infection among physically and sexually abused women was 0.7 percent, compared with 0.2 percent among women who had experienced no abuse. Indeed, those who had experienced violence were 3.9 times more likely than those who had not, to be HIV infected, even after adjusting for socio-demographic characteristics and women's sexual risk behaviours. While the cross-sectional nature of these associations makes causality difficult to establish, researchers suggest that sexual violence increases HIV risk because the physical trauma (lacerations) women may experience as a result of forced sex could provide the virus with a means of entry into the body
(Silverman et al., 2008). A second study explored the association between intimate partner violence and HIV among husband-wife dyads drawn from the NFHS-3 survey (20,425 dyads in total) and using logistic regression models, concluded that women in abusive relationships were at heightened risk of HIV; odds ratios were 7 times higher among those in abusive relationships (AOR 7.22) than those in non-abusive ones. Findings highlight that abused women faced increased HIV risk based on both the greater likelihood of HIV infection among abusive husbands and elevated HIV transmission within abusive relationships (Decker et al., 2009). Both studies conclude that violence functions both as a risk marker and as a risk factor for HIV among women.

Table 3.9 presents evidence from young women, from the Youth Study, the three district study in Andhra Pradesh and Madhya Pradesh, and the study in Pune district, which underscores the strength of the association between marital violence and the experience of symptoms of RTI or STI. Indeed, the association was significantly positive in all three studies, for both physical and sexual violence, and for both lifetime experience of violence as well as violence experienced in the recent past, that is, in the year prior to the interview (among women who had cohabited for one year or more). Indeed, consolidated findings for the six states of the Youth Study show that those who had experienced any form of violence were 1.8-1.9 times more likely than others to have experienced symptoms of RTI or STI in the three months prior to the interview. The Pune district study and the three district study in Andhra Pradesh and Madhya Pradesh also show 
Figure 3.3 Association between marital violence and experience of clinically/laboratory detected RTI/STI

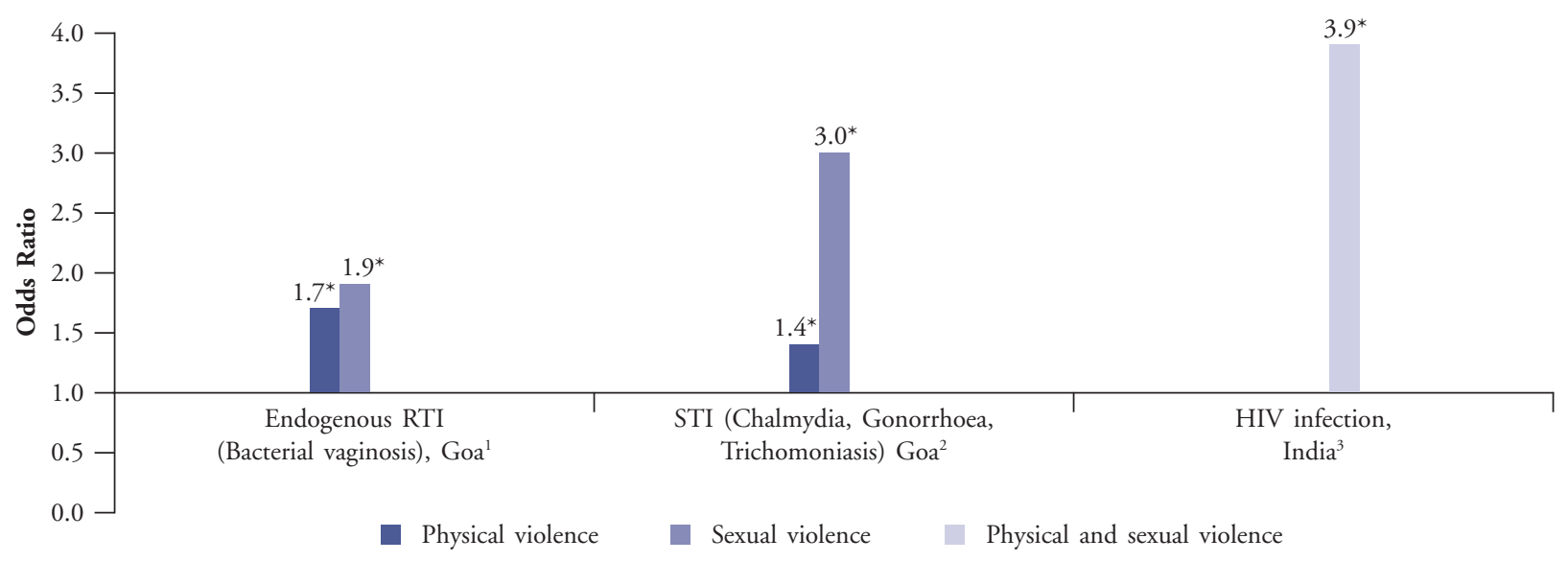

*Statistically significant at 05 level or better, after controlling for the effects of a range of socio-demographic factors.

Source: ${ }^{1}$ Patel et al., 2006; ${ }^{2}$ Weiss et al., 2008; ${ }^{3}$ Silverman et al., 2008.

Table 3.9:

Association between marital violence experienced by currently married young women and recent experience of symptoms of RTI/STI: Findings from various surveys, 2000s

\begin{tabular}{|c|c|c|c|c|}
\hline \multirow[t]{3}{*}{ Site } & \multicolumn{2}{|c|}{ Physical violence } & \multicolumn{2}{|c|}{ Sexual violence } \\
\hline & \multicolumn{2}{|c|}{ Odds ratios } & \multicolumn{2}{|c|}{ Odds ratios } \\
\hline & Ever experienced ${ }^{\mathrm{a}}$ & $\begin{array}{l}\text { Experienced in last } \\
12 \text { months }^{b}\end{array}$ & Ever experienced ${ }^{\mathrm{a}}$ & $\begin{array}{l}\text { Experienced in last } \\
12 \text { months }^{b}\end{array}$ \\
\hline 6 states $^{1}$ & $1.80^{* * *}$ & $1.87^{* * *}$ & $1.81^{* * *}$ & $1.81^{* * *}$ \\
\hline Bihar $^{1}$ & $1.76^{* * *}$ & $1.84^{* * *}$ & $1.42^{*}$ & $1.39^{*}$ \\
\hline Jharkhand $^{1}$ & $1.82^{* * *}$ & $1.81^{* * *}$ & $1.62^{* * *}$ & $1.68^{* * *}$ \\
\hline Rajasthan ${ }^{1}$ & $1.75^{* * *}$ & $1.88^{* * *}$ & 1.21 & $1.44^{*}$ \\
\hline Maharashtra $^{1}$ & $2.18^{* * *}$ & $2.39^{* * *}$ & $2.15^{* * *}$ & $2.01^{* * *}$ \\
\hline Andhra Pradesh ${ }^{1}$ & $2.17^{* * *}$ & $2.32^{* *}$ & $2.58^{* * *}$ & $2.90^{* * *}$ \\
\hline Tamil Nadu ${ }^{1}$ & $1.37^{* *}$ & $1.69^{* *}$ & 1.26 & 1.07 \\
\hline $\mathrm{AP} / \mathrm{MP}^{2}$ & $1.40^{* *}$ & $1.39^{* *}$ & $1.35^{* *}$ & $1.50^{* *}$ \\
\hline Pune district ${ }^{3}$ & $2.42^{* * *}$ & NA & $1.67^{* * *}$ & NA \\
\hline
\end{tabular}

"Among currently married women (aged 15-24).

${ }^{b}$ Among currently married women (aged 15-24) who had cohabited for one year or more. ${ }^{*} p<=0.05 ;{ }^{* *} p<=0.01 ;{ }^{* * *} p<=0.001$.

Reference period is three months preceding the interview for all studies except the AP/MP study where the reference period is one year preceding the interview; $A P=$ Andhra Pradesh; $M P=$ Madhya Pradesh; NA: not available, not asked.

Source: ${ }^{1}$ IIPS and Population Council, 2010; ${ }^{2}$ Santhya, Jejeebhoy and Ghosh, 2008; ${ }^{3}$ Alexander et al., 2006. 
a similarly strong and significant positive association between lifetime experience of physical and sexual violence and symptoms of genital infection (OR 2.4 and 1.7, respectively, in the Pune district study; $1.4-1.5$ in the three district study).

Indeed, the Pune study described above also observed that individual symptoms such as foul smelling discharge, genital ulcers, itching in the genitals, swelling in the groin area and burning while passing urine were consistently and significantly more likely to be experienced by young women who had ever experienced physical (2-4 times more likely) and sexual violence (about twice as likely), respectively, than women who had not experienced abuse.

Several reasons, biological and socio-cultural, are hypothesised in the literature for the link between marital violence and RTI/STI/HIV. First, there is evidence that men who admitted perpetrating violence on their wife also admitted multiple partner sexual relations, the non-use of condoms and reported symptoms of infection (Martin et al., 1999; Verma and Collumbien, 2003), thereby placing their wife at risk of acquiring infection. Second, the physical trauma caused by physical and sexual violence may result in gynaecological morbidity; moreover sexual violence may cause vaginal or urethral trauma that may exacerbate women's risk of acquiring an infection (Stephenson, Koenig and Ahmed, 2006b). At the same time, women in abusive relationships may be less able than other women to negotiate condom use. A qualitative study that probed marital violence and the interrelation between gender norms, domestic violence and women's risk of HIV in the slums of Chennai highlights that as a result of the experience and/or fear of violence, many women reported that they were unable to refuse sex with their husband on the one hand, and negotiate condom use and use condoms in sexual encounters with their husband on the other, even if they suspected their husband of engaging in sex with multiple partners (Go et al., 2003).

\section{Pregnancy-related complications and care seeking}

The few studies, summarised in Table 3.10 and Figure 3.4, that have explored the links between pregnancy-related complications and care seeking and marital violence observe, by and large, an inverse association. For example, a communitybased study in Uttar Pradesh reveals that women who experienced physical violence before or during pregnancy were significantly less likely than those who did not so experience to seek antenatal care, while no such association was observed with regard to delivery care or postpartum care (Ahmed, Koenig and Stephenson, 2006). Another study was a longitudinal study that explored the effect of physical violence during pregnancy on antenatal care, using data from the NFHS-2 (1998-99) and the follow-up survey of women in four states (Bihar, Jharkhand, Maharashtra and Tamil Nadu). Analysis was conducted among a sample of 2,877 women who had a birth during the inter-survey period. Findings show that women who experienced physical violence during pregnancy were significantly less likely than those who had not experienced violence to have obtained any antenatal care (OR 0.81), a home visit 


\section{Table 3.10:}

Association between marital violence and pregnancy-related complications and care seeking: Findings from various studies, 1990s-2000s

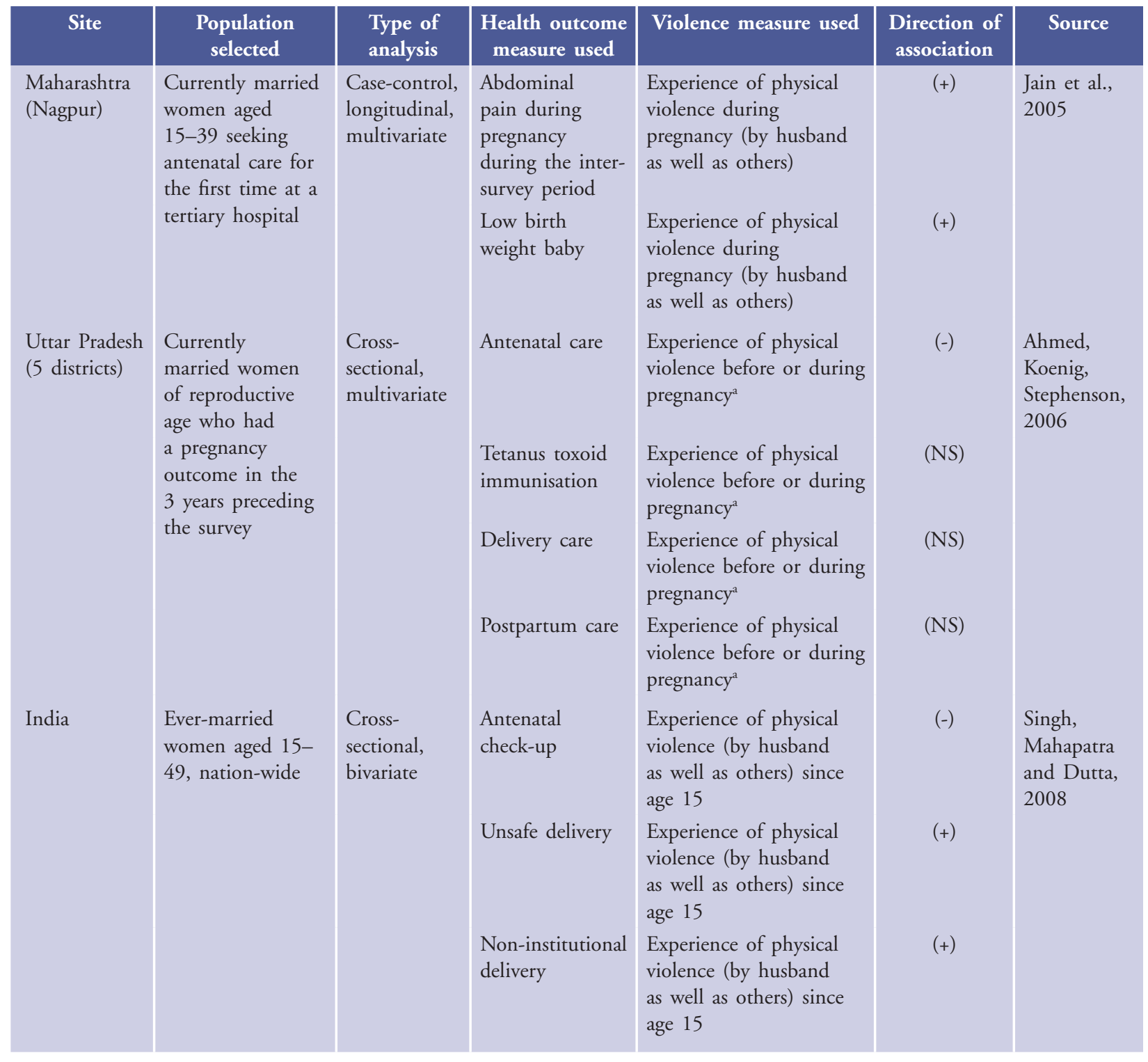


Table 3.10: (Cont'd)

\begin{tabular}{|c|c|c|c|c|c|c|}
\hline Site & $\begin{array}{l}\text { Population } \\
\text { selected }\end{array}$ & $\begin{array}{l}\text { Type of } \\
\text { analysis }\end{array}$ & $\begin{array}{l}\text { Health outcome } \\
\text { measure used }\end{array}$ & Violence measure used & $\begin{array}{l}\text { Direction of } \\
\text { association }\end{array}$ & Source \\
\hline $\begin{array}{l}\text { Bihar, } \\
\text { Jharkhand, } \\
\text { Maharashtra, } \\
\text { Tamil Nadu }\end{array}$ & $\begin{array}{l}\text { Currently married } \\
\text { women aged } \\
15-49 \text { with at } \\
\text { least one birth } \\
\text { during the period } \\
\text { between the } \\
\text { NFHS-2 (1998- } \\
99 \text { ) and followed } \\
\text { up in 2002-03, } \\
\text { rural, state-wide }\end{array}$ & $\begin{array}{l}\text { Longitudinal, } \\
\text { multivariate }\end{array}$ & $\begin{array}{l}\text { Any home-based } \\
\text { antenatal care } \\
3 \text { or more } \\
\text { antenatal visits } \\
\text { First antenatal } \\
\text { check-up in } 2^{\text {nd }} \\
\text { or } 3^{\text {rd }} \text { trimester }\end{array}$ & $\begin{array}{l}\text { Experience of physical } \\
\text { violence during the most } \\
\text { recent pregnancy } \\
\text { Experience of physical } \\
\text { violence during the most } \\
\text { recent pregnancy } \\
\text { Experience of physical } \\
\text { violence during the most } \\
\text { recent pregnancy } \\
\text { Experience of physical } \\
\text { violence during the most } \\
\text { recent pregnancy }\end{array}$ & $(+)$ & $\begin{array}{l}\text { Koski, } \\
\text { Stephenson } \\
\text { and Koenig, } \\
2010\end{array}$ \\
\hline $\begin{array}{l}\text { Maharashtra } \\
\text { (Nagpur) }\end{array}$ & $\begin{array}{l}\text { Currently married } \\
\text { women (age not } \\
\text { specified) seeking } \\
\text { antenatal care } \\
\text { ( } 28-40 \text { weeks } \\
\text { of pregnancy), } \\
\text { secondary and } \\
\text { tertiary hospitals }\end{array}$ & $\begin{array}{l}\text { Cross- } \\
\text { sectional, } \\
\text { bivariate }\end{array}$ & $\begin{array}{l}\text { Antenatal care } \\
\text { seeking before } \\
32 \text { weeks of } \\
\text { gestation }\end{array}$ & $\begin{array}{l}\text { Experience of physical } \\
\text { violence (by husband as } \\
\text { well as others) during } \\
\text { pregnancy }\end{array}$ & $(-)$ & $\begin{array}{l}\text { Purwar et } \\
\text { al., } 1999\end{array}$ \\
\hline Delhi & $\begin{array}{l}\text { Currently married } \\
\text { women (age not } \\
\text { specified) who } \\
\text { had delivered in a } \\
\text { tertiary hospital }\end{array}$ & $\begin{array}{l}\text { Cross- } \\
\text { sectional, } \\
\text { bivariate }\end{array}$ & $\begin{array}{l}\text { Pregnancy- } \\
\text { related } \\
\text { complications }\end{array}$ & $\begin{array}{l}\text { Experience of physical } \\
\text { violence (by husband as } \\
\text { well as others) during } \\
\text { pregnancy } \\
\text { Experience of physical } \\
\text { violence during } \\
\text { pregnancy }\end{array}$ & $(+)$ & $\begin{array}{l}\text { Muthal- } \\
\text { Rathore, } \\
\text { Tripathi and } \\
\text { Arora, } 2002\end{array}$ \\
\hline
\end{tabular}

'Women's experience of physical andlor sexual violence was measured by the husband's reports of perpetration of marital violence. $(N S)=$ Not significant $(+)=$ significant positive association, $p<=0.05 ;(-)=$ significant negative association, $p<=0.05$. 
for antenatal care (OR 0.43) or a minimum of three antenatal checkups (OR 0.88); they were also more likely to have had their first antenatal checkup in the second or third trimester of pregnancy (hazards ratios of 1.2 and 1.6, respectively) (Koski, Stephenson and Koenig, 2010). Similar findings were obtained in a facility-based survey in rural and urban areas of Nagpur that shows that abused women were twice as likely as other women to delay seeking antenatal care until after 32 weeks of pregnancy (OR 2.5; Purwar et al., 1999).

Other studies, using less rigorous analytic techniques, also suggest an inverse association between marital violence and pregnancy-related care. For example, an analysis of NFHS-2 data shows that women who experienced physical violence from the age of 15 were less likely to have received antenatal check-ups or to have had an institutional delivery than women who had not experienced such violence (Singh, Mahapatra and Dutta, 2008). It may be noted, however, that the analysis did not control for confounding factors.

Very few studies have explored the association between marital violence and women's experience of pregnancy-related complications. Findings from these studies show a positive association between marital violence and pregnancy-related complications. For example, in a facility-based study conducted among women seeking antenatal care at a hospital in Maharashtra, after controlling for maternal age, gravidity and husband's alcohol use, women exposed to marital violence remained significantly more likely than others to have experienced abdominal pain during pregnancy and deliver a low birth weight

Figure 3.4: Association between marital violence and pregnancy-related complications and care seeking

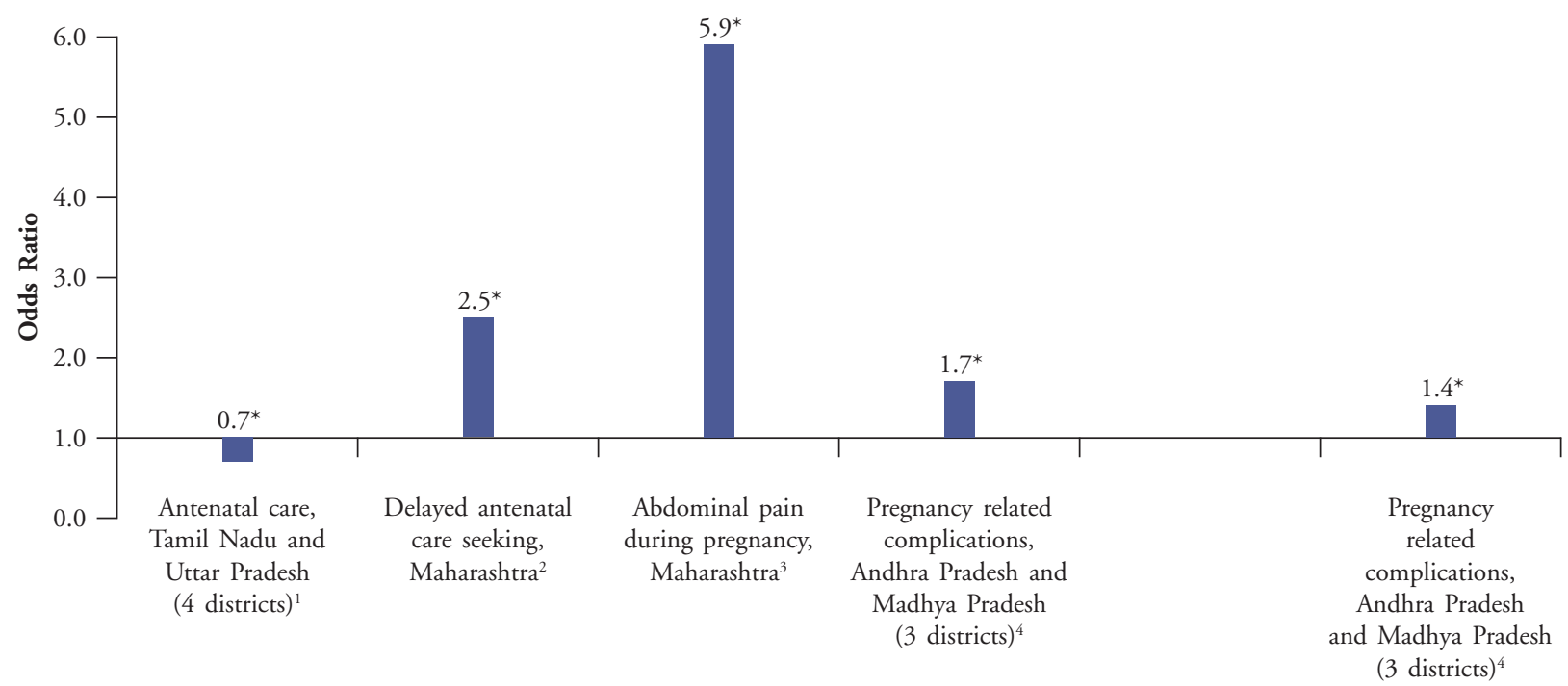

*Statistically significant at 05 level or better, after controlling for the effects of a range of socio-demographic factors.

Source: ' ${ }^{\text {Ahmed, Koenig and Stephenson, 2006; }{ }^{2} \text { Purwar et al., 1999; }{ }^{3} J a i n ~ e t ~ a l ., ~ 2005 ; ~}{ }^{4}$ Santhya, Jejeebhoy and Ghosh, 2008. 
baby (RR 5.91, $\mathrm{p}=0.014$ and $R R$ 2.48, $\mathrm{p}=0.023$, respectively) (Jain et al., 2005). Another facilitybased study of recently delivered women interviewed in a postnatal ward of a tertiary hospital also observed that women who had experienced physical violence (mostly perpetrated by their husband, but also by other family members) were significantly more likely than others to experience pregnancyrelated complications and deliver a low-birth weight infant (Muthal-Rathore, Tripathi and Arora, 2002).

Few studies have explored the association between marital violence and young women's pregnancy-related complications. Findings from the three district study in Andhra Pradesh and Madhya Pradesh suggest that among women who had ever been pregnant, those who had ever experienced physical or sexual violence in their married life were more likely that those who had not experienced abuse to have experienced pregnancy-related complications during their most recent birth, even after controlling for such background factors as age, parity, education, work status, household economic status and type of family (OR 1.74 and 1.35, respectively).

In addition to pregnancy-related complications, maternal mortality has been observed to be a consequence of partner violence. For example, a study in Pune shows that 16 percent of all deaths during pregnancy were the result of partner violence (Ganatra, Coyaji and Rao, 1998).

\section{Foetal, perinatal and early childhood mortality}

Unlike in the case of pregnancy-related complications and care seeking, a number of studies, both community-based and facility-based, in India have examined the association between marital violence and foetal mortality as well as perinatal, neonatal, infant and early childhood mortality, as reported in Table 3.11 and Figures 3.5 and 3.6. These studies have consistently shown that marital violence increases the risk of foetal, infant and early childhood mortality.

A prospective follow-up study of a cohort of women aged 15-39 selected from the 1998-99 NFHS-2 and followed-up in 2002-03 from four states (Bihar, Jharkhand, Maharashtra and Tamil Nadu) observed a clear association between the experience of violence and perinatal and neonatal mortality. Even after controlling for such confounding factors as age, parity, woman's and husband's education levels, sex of the child, household assets, caste, antenatal care experience and state of residence, the study observed that relative to the reference group of women who experienced no recent domestic violence, perinatal and neonatal mortality rates were higher (hazards ratio 1.85 and 1.62 , respectively) among women who reported multiple episodes of recent violence; those experiencing one episode of violence were not at higher risk of mortality than others (Koenig et al., 2010).

A study in Uttar Pradesh that explored the links between men's responses regarding the perpetration of physical violence before or during pregnancy and women's responses regarding pregnancy outcomes and child survival in the threeyear period prior to the women's interview reports that women who experienced marital violence during pregnancy experienced significantly high risks of both perinatal and neonatal mortality (in both cases, more than twice the risk), after controlling for a host of 
Figure 3.5: Association between physical violence within marriage and foetal, perinatal and neonatal mortality

$$
\text { Foetal mortality Perinatal mortality Neonatal mortality }
$$

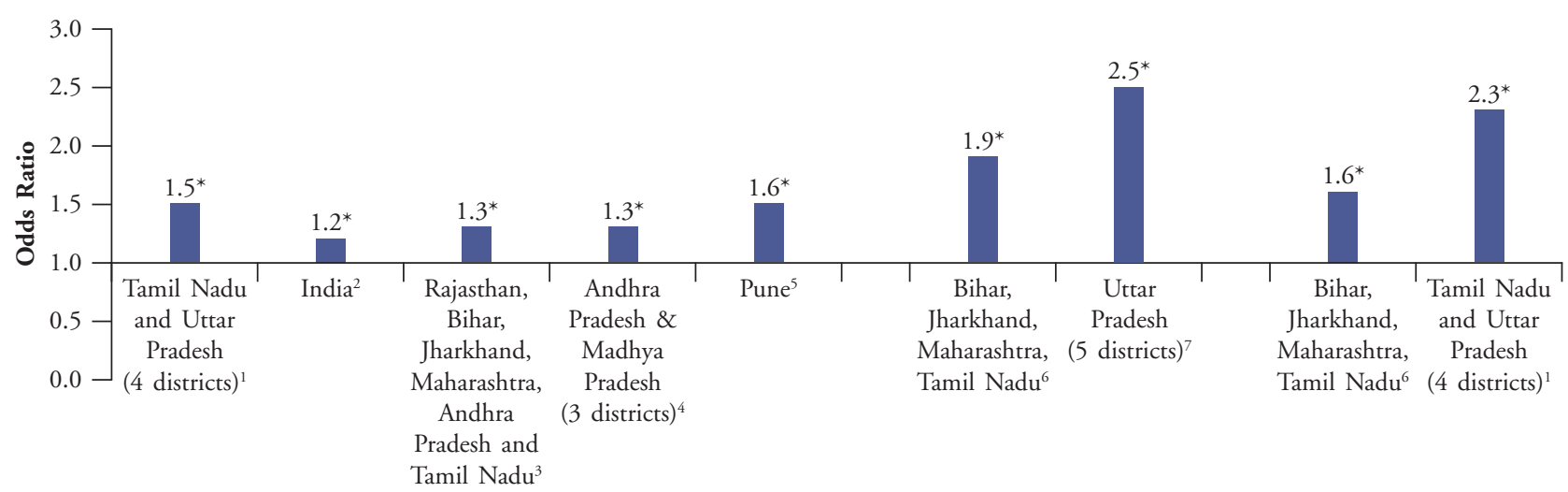

*Statistically significant at .05 level or better, after controlling for the effects of a range of socio-demographic factors.

Source: ${ }^{1}$ Jejeebhoy, 1998; ${ }^{2} J o h n s o n$ and Sengupta, 2008; ${ }^{3} I I P S$ and Population Council, 2010; ${ }^{4}$ Santhya, Jejeebhoy and Ghosh, 2008; ${ }^{5}$ Alexander et al., 2006; ' ${ }^{K}$ Koenig et al., 2010; ${ }^{7}$ Ahmed, Koenig and Stephenson, 2006; ${ }^{8}$ Singh, Mahapatra and Dutta. 2008; ' Ackerson and Subramanian. 2009.

Figure 3.6: Association between physical violence within marriage and infant and early childhood mortality

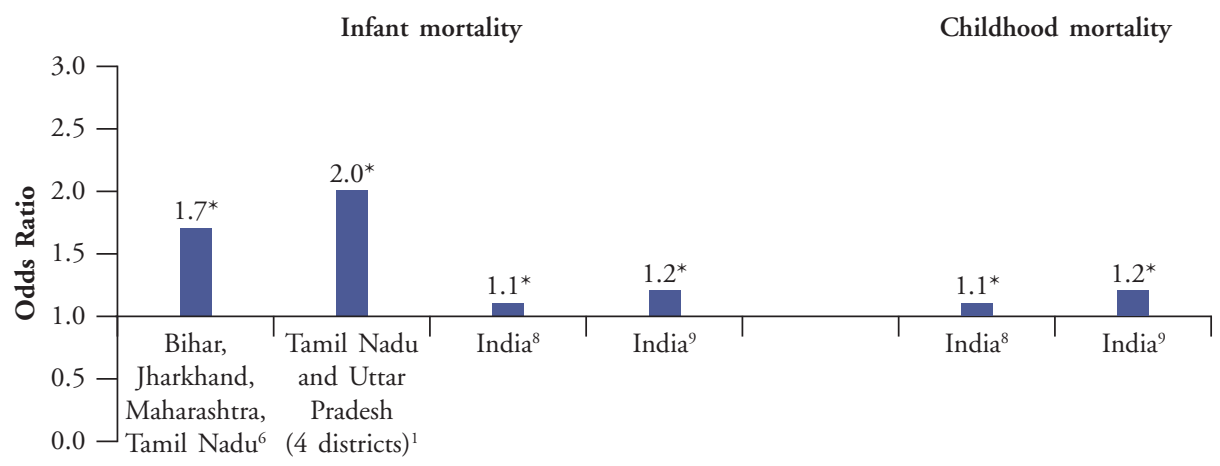

*Statistically significant at .05 level or better, after controlling for the effects of a range of socio-demographic factors.

Source: ${ }^{1}$ Jejeebhoy, 1998; ${ }^{2} J o h n s o n$ and Sengupta, 2008; ${ }^{3}$ IIPS and Population Council, 2010; ${ }^{4}$ Santhya, Jejeebhoy and Ghosh, 2008; ${ }^{5}$ Alexander et al., 2006; ' ${ }^{K}$ Koenig et al., 2010; ${ }^{7}$ Ahmed, Koenig and Stephenson, 2006; ${ }^{8}$ Singh, Mahapatra and Dutta. 2008; ${ }^{9}$ Ackerson and Subramanian. 2009.

other factors (Ahmed, Koenig, Stephenson, 2006). Indeed, the authors estimate that approximately 1 in 5 stillbirths and neonatal deaths could potentially have been averted had marital violence been prevented.
Likewise, a study of women aged 15-39 in two districts each of Tamil Nadu and Uttar Pradesh found that wife-beating was deeply entrenched and that the health consequences of this violence in terms of pregnancy loss and infant mortality were 
considerable (Jejeebhoy, 1998b). Logistic regression analyses reveal a powerful association between women's experience of wife-beating and foetal loss (OR 1.47), infant loss (OR 2.02) and foetal or infant loss (OR 1.84), even after such well-known correlates as education and parity were controlled. Findings suggest moreover that the associations were stronger in Uttar Pradesh, a more gender-hierarchical setting, than in Tamil Nadu, where women have some measure of autonomy and social support from kin. Again, while this study established a strong and consistent association, the cross-sectional data did not allow for the establishment of the direction of causality.

The association between marital violence and foetal, perinatal and early childhood mortality has been examined using NFHS-2 and NFHS-3 data as well. One of these studies, using NFHS-2 data, reports that physical violence experienced by women since the age of 15 perpetrated by their husband or other family members increased the risk of infant and child death (Singh, Mahapatra and Dutta, 2008). The second study, also using NFHS-2 data, examined the link between women's experience of physical violence since age 15 perpetrated by their husband and involuntary foetal death, i.e., spontaneous abortion or stillbirth, and infant death. Findings note that involuntary foetal death was directly correlated with physical violence within marriage, while infant death (among women who had a birth after 1995, excluding those who had given birth in the two months preceding the survey $(\mathrm{N}=68,887)$ was not (Johnson and Sengupta, 2008). A third study using data from NFHS-3 analysed the association between the experience of violence and infant mortality using data from 7,155 children born 0-11 months before the interview, and associations between the experience of violence and child mortality using data from 30,466 children born more than 12 months but less than 60 months before the interview and who survived up to 12 months or longer. Findings show that maternal experience of physical violence (from age 15 onwards) was associated with increased mortality rates among all children, that is, children below age 5 (0-59 months) (RR 1.21), infants (0-11 months) (RR 1.24) and older children (12-59 months) (RR 1.25). Sexual violence, in contrast, was significantly associated with infant mortality (RR 1.41) but not child mortality (Ackerson and Subramanian, 2009).

Surveys of young women who had ever experienced pregnancy, reported in Table 3.12, suggest a positive association between the experience of physical violence and any foetal mortalitystillbirth or miscarriage: indeed, the Youth study has observed that young women who had experienced physical violence at any time within their married life were 1.3 times more likely than those who had not to have experienced foetal mortality, and those in Bihar, Maharashtra and Tamil Nadu were 1.4-1.6 times more likely to have done so. Experience of violence in the first year of marriage was similarly powerfully associated with foetal mortality when respondents from all six states were considered; it was less likely to be significant when individual states were considered. Similar strong and significant associations were observed between the experience of physical violence over the course of married life and the experience of foetal mortality in both the three district study in Andhra Pradesh and Madhya 


\section{Table 3.11:}

Association between marital violence and foetal, perinatal and early childhood mortality: Findings from various studies, 1990s-2000s

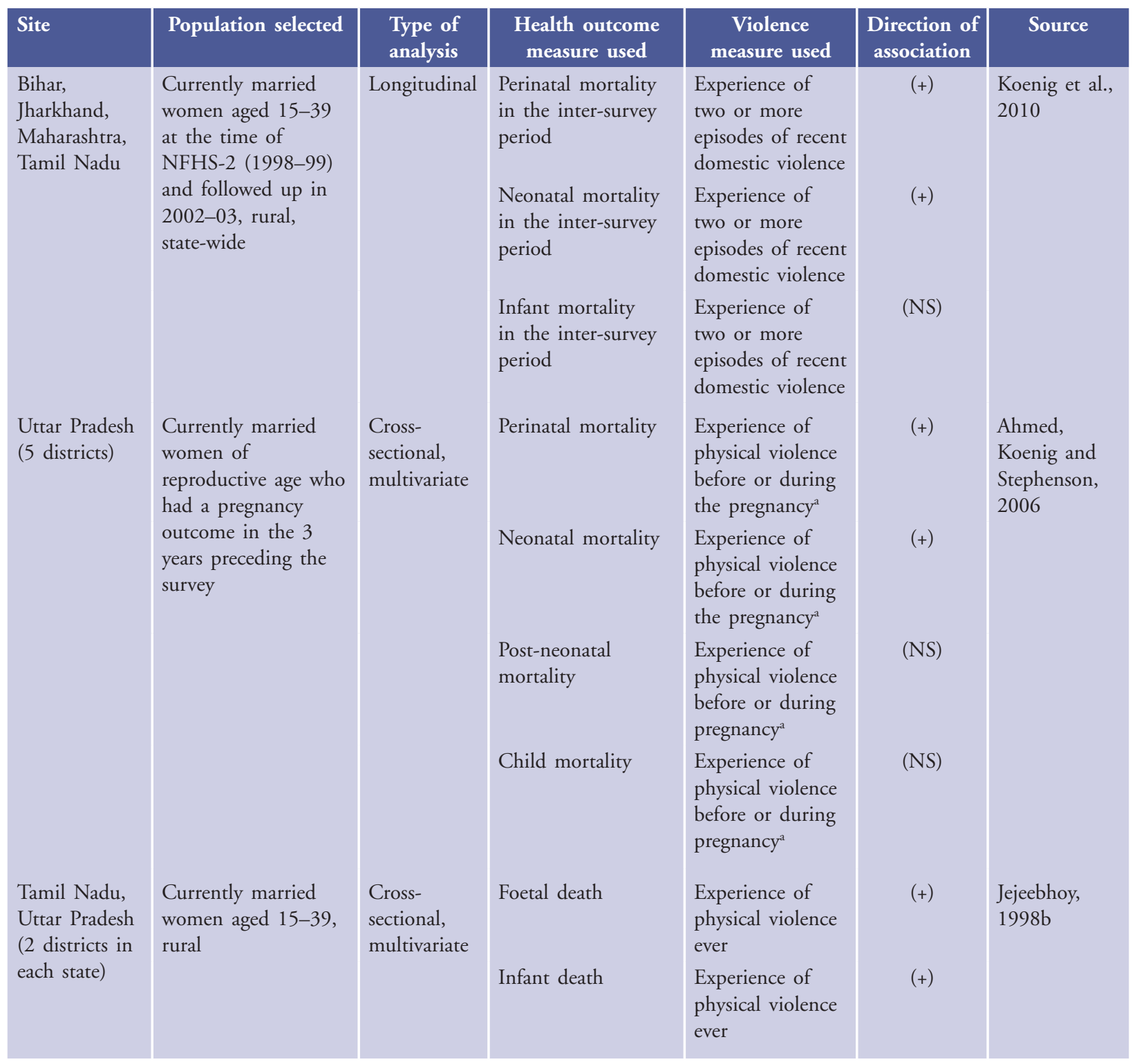


Table 3.11: (Cont'd)

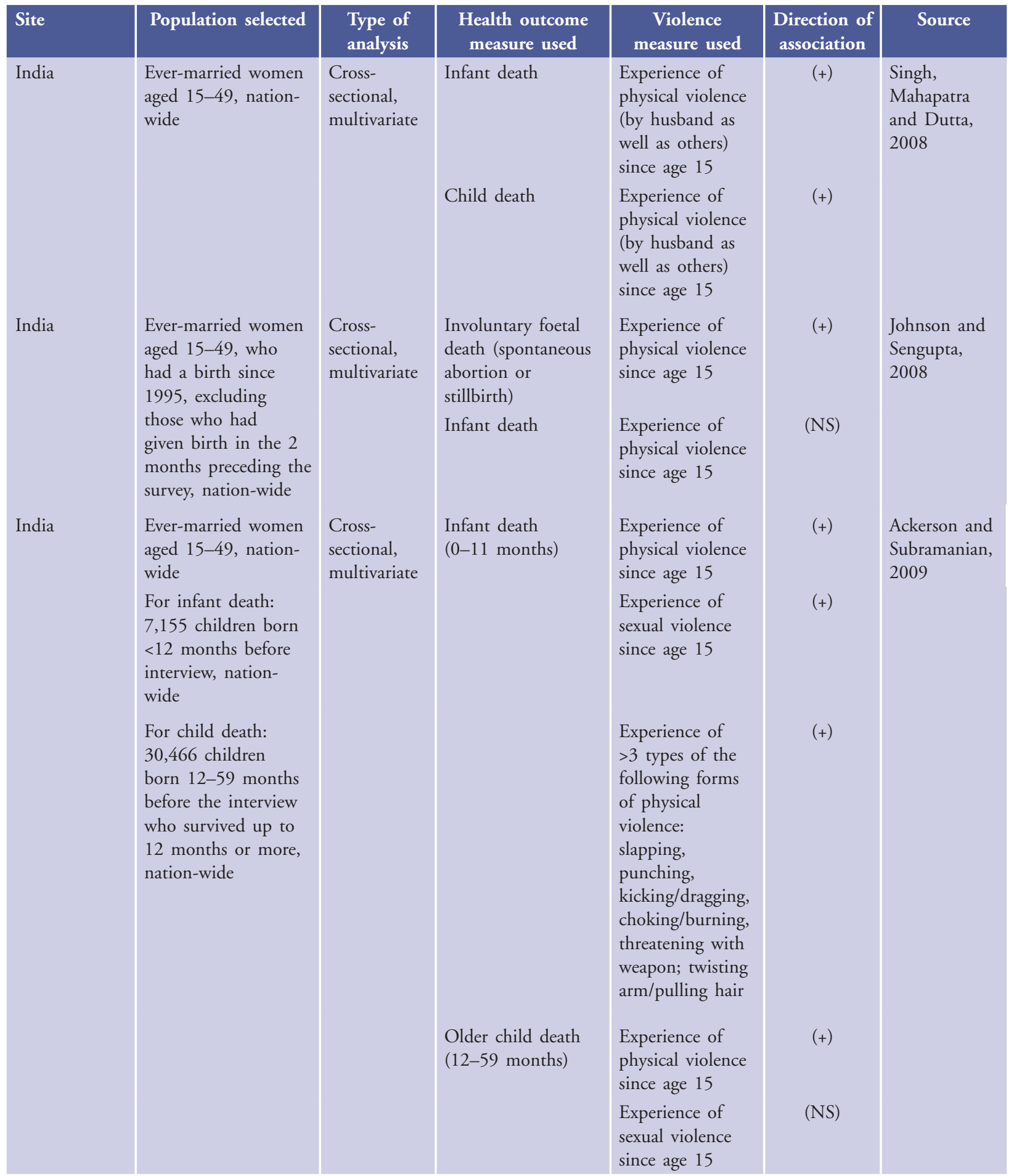


Table 3.11: (Cont'd)

\begin{tabular}{|c|c|c|c|c|c|c|}
\hline Site & Population selected & $\begin{array}{l}\text { Type of } \\
\text { analysis }\end{array}$ & $\begin{array}{l}\text { Health outcome } \\
\text { measure used }\end{array}$ & $\begin{array}{c}\text { Violence } \\
\text { measure used }\end{array}$ & $\begin{array}{c}\text { Direction of } \\
\text { association }\end{array}$ & Source \\
\hline $\begin{array}{l}\text { Maharashtra } \\
\text { (Nagpur) }\end{array}$ & $\begin{array}{l}\text { Currently married } \\
\text { women aged } 15-39 \\
\text { seeking antenatal care } \\
\text { for the first time at a } \\
\text { tertiary hospital }\end{array}$ & $\begin{array}{l}\text { Case- } \\
\text { control, } \\
\text { longitudinal, } \\
\text { multivariate }\end{array}$ & $\begin{array}{l}\text { Any child death } \\
(0-59 \text { months }) \\
\text { Adverse foetal } \\
\text { outcomes (stillbirth, } \\
\text { foetal death) }\end{array}$ & $\begin{array}{l}\text { Experience of } \\
>3 \text { types of the } \\
\text { following forms } \\
\text { of physical } \\
\text { violence: } \\
\text { slapping, } \\
\text { punching, } \\
\text { kicking/dragging, } \\
\text { choking/burning, } \\
\text { threatening with } \\
\text { weapon; twisting } \\
\text { arm/pulling hair } \\
\text { Experience of } \\
\text { physical violence } \\
\text { since age } 15 \\
\text { Experience of } \\
\text { sexual violence } \\
\text { since age } 15 \\
\text { Experience of } \\
>3 \text { types of the } \\
\text { following forms } \\
\text { of physical } \\
\text { violence: } \\
\text { slapping, } \\
\text { punching, } \\
\text { kicking/dragging, } \\
\text { choking/burning, } \\
\text { threatening with } \\
\text { weapon; twisting } \\
\text { arm/pulling hair } \\
\text { Experience of } \\
\text { physical violence } \\
\text { (by husband as } \\
\text { well as others) } \\
\text { during pregnancy }\end{array}$ & $\begin{array}{c}(+) \\
(\mathrm{NS}) \\
(+)\end{array}$ & $\begin{array}{l}\text { Jain et al., } \\
2005\end{array}$ \\
\hline
\end{tabular}

${ }^{a}$ Women's experience of physical andlor sexual violence was measured by the husband's reports of perpetration of marital violence. $(N S)=$ Not significant $;(+)=$ significant positive association, $p<=0.05 ;(-)=$ significant negative association, $p<=0.05$. 


\section{Table 3.12:}

Association between marital violence experienced by currently married young women and experience of any foetal mortality (stillbirth or miscarriage): Findings from various surveys, 2000s

\begin{tabular}{|c|c|c|c|c|}
\hline \multirow[t]{3}{*}{ Site } & \multicolumn{2}{|c|}{ Physical violence } & \multicolumn{2}{|c|}{ Sexual violence } \\
\hline & \multicolumn{2}{|c|}{ Odds ratios } & \multicolumn{2}{|c|}{ Odds ratios } \\
\hline & Ever experienced ${ }^{a}$ & $\begin{array}{c}\text { Experienced in first } \\
12 \text { months of marriage }\end{array}$ & Ever experienced ${ }^{a}$ & $\begin{array}{l}\text { Experienced at } \\
\text { initiation }^{\mathrm{a}}\end{array}$ \\
\hline 6 states $^{1}$ & $1.33^{* * *}$ & $1.32^{* *}$ & 1.05 & 1.05 \\
\hline Bihar $^{1}$ & $1.56^{* *}$ & 1.37 & 0.92 & 0.97 \\
\hline Jharkhand $^{1}$ & 1.21 & 1.19 & 1.27 & 1.22 \\
\hline Rajasthan ${ }^{1}$ & 1.25 & $1.59^{*}$ & 1.10 & 1.10 \\
\hline Maharashtra $^{1}$ & $1.36^{*}$ & 1.34 & 1.17 & 1.19 \\
\hline Andhra Pradesh ${ }^{1}$ & 1.07 & 1.18 & 1.30 & 1.26 \\
\hline Tamil Nadu ${ }^{1}$ & $1.54^{* *}$ & 1.39 & 1.06 & 1.00 \\
\hline $\mathrm{AP} / \mathrm{MP}^{2}$ & $1.34^{*}$ & NA & 0.94 & 1.04 \\
\hline Pune district ${ }^{3}$ & $1.58^{* *}$ & NA & 1.24 & 1.17 \\
\hline
\end{tabular}

"Among currently married women (aged 15-24) who had ever experienced a pregnancy.

${ }^{b}$ Among currently married women (aged 15-24) who had cohabited for one year or more and had ever experienced a pregnancy. ${ }^{*} p<=0.05 ;{ }^{* *} p<=0.01 ;{ }^{* * *} p<=0.001$.

AP $=$ Andhra Pradesh; MP=Madhya Pradesh; NA: not available, not asked.

Source: ${ }^{1}$ IIPS and Population Council, 2010; ${ }^{2}$ Santhya, Jejeebhoy and Ghosh, 2008; ${ }^{3}$ Alexander et al., 2006.

Pradesh, and the Pune district study. Experience of sexual violence was, however, unrelated with foetal mortality in all three studies.

Evidence from young men is presented in Table 3.13. The Youth study shows remarkably similar findings among young men whose wife had ever been pregnant as it did among young women. Young men who had perpetrated physical violence on their wife-ever or in the first year of marriagewere 1.5 times more likely to report foetal mortality than were other young men. State-wise differences were not as consistent as observed among young women; indeed, a significant positive association was observed only in Tamil Nadu (OR 1.4-1.5 in the case of ever having perpetrated physical violence and perpetrating it early in marriage), and Jharkhand (OR 2.6 in the case of having perpetrated physical violence early in marriage). The three district study in Andhra Pradesh and Madhya Pradesh and the Pune district study, however, did not report any significant correlation between young men's report of perpetration of physical violence and their wife's experience of foetal mortality.

A significant positive association was also observed in the Youth Study and the Pune district study between young men's perpetration of sexual violence at any time in marriage and foetal mortality: odds ratios ranged from 1.6 in the Youth Study to 2.9 in the Pune district study. However, Youth Study findings at the state level did not show a significant association, for the most part, between the perpetration of sexual violence and foetal mortality, except in Bihar, where young men who had perpetrated sexual violence at any time in their married life were twice as likely as others to report foetal mortality. The three district study in Andhra 


\section{Table 3.13:}

Association between marital violence perpetrated by currently married young men and experience of any foetal mortality (stillbirth or miscarriage): Findings from various surveys, 2000s

\begin{tabular}{|c|c|c|c|c|}
\hline \multirow[t]{3}{*}{ Site } & \multicolumn{2}{|c|}{ Physical violence } & \multicolumn{2}{|c|}{ Sexual violence } \\
\hline & \multicolumn{2}{|c|}{ Odds ratios } & \multicolumn{2}{|c|}{ Odds ratios } \\
\hline & Ever perpetrated ${ }^{a}$ & $\begin{array}{l}\text { Perpetrated in first } 12 \\
\text { months of marriage }\end{array}$ & Ever perpetrated ${ }^{\mathrm{a}}$ & $\begin{array}{l}\text { Perpetrated at } \\
\text { initiation }^{\mathrm{a}}\end{array}$ \\
\hline 6 states $^{1}$ & $1.50^{* * *}$ & $1.48^{* *}$ & $1.56^{* *}$ & 1.17 \\
\hline Bihar $^{1}$ & 1.14 & 1.42 & $1.91^{*}$ & 1.32 \\
\hline Jharkhand $^{1}$ & 1.72 & $2.56^{*}$ & 1.62 & 1.40 \\
\hline Rajasthan ${ }^{1}$ & 1.59 & 0.46 & 0.88 & 0.71 \\
\hline Maharashtra ${ }^{1}$ & 1.49 & 1.39 & 1.15 & 0.47 \\
\hline Andhra Pradesh ${ }^{1}$ & 1.59 & 1.87 & 1.68 & 1.71 \\
\hline Tamil Nadu ${ }^{1}$ & $1.42^{*}$ & $1.48^{*}$ & 0.89 & 1.06 \\
\hline $\mathrm{AP} / \mathrm{MP}^{2}$ & 1.16 & NA & 0.75 & 0.62 \\
\hline Pune district ${ }^{3, c}$ & 1.56 & NA & $2.86^{* *}$ & 2.45 \\
\hline
\end{tabular}

"Among currently married men (aged 15-29) whose wife had ever experienced a pregnancy.

${ }^{b}$ Among currently married men (15-29) who had cohabited for one year or more and whose wife had ever experienced a pregnancy.

'Among currently married men (aged 15-24) whose wife had ever experienced a pregnancy.

${ }^{*} p<=0.05 ;{ }^{* *} p<=0.01 ;{ }^{* * *} p<=0.001$.

$A P=$ Andhra Pradesh; MP=Madhya Pradesh; NA: not available, not asked.

Source: ${ }^{1}$ IIPS and Population Council, 2010; ${ }^{2}$ Santhya, Jejeebhoy and Ghosh, 2008; ${ }^{3}$ Alexander et al., 2006.

Pradesh and Madhya Pradesh did not observe any significant association between young men's reports of perpetration of sexual violence and their wife's experience of foetal mortality.

The pathways through which domestic violence may lead to elevated risks for foetal, perinatal and childhood mortality are not fully understood, but are both direct and indirect (Monemi, 2008). The direct link refers to physical trauma followed by foetal death or a subsequent adverse pregnancy outcome; violent acts during pregnancy may lead to foetal injury, preterm delivery or stillbirth, and provoke serious uterine bleeding. Domestic violence may also hamper a woman's ability to provide child care; for example, an analysis of NFHS-3 data suggests that infants of women who had experienced marital violence were less likely than other children to have been fully immunised (Kishor and Gupta, 2009). A second potential pathway is elevated maternal stress and poor nutrition, both of which are associated with low birth weight and preterm delivery, which are well-known risk factors for perinatal and infant mortality. Stress and depression may also reduce a woman's ability to care for her child. A third possible pathway is the deterrent effect of violence on women's utilisation of health care services during pregnancy, at the time of delivery and thereafter (Ahmed, Koenig and Stephenson, 2006). Finally, and related, abused women may be less likely than others to have the autonomy-decision-making power, control over resources, for example—or the social support that are necessary to care for their children's health care needs. 


\section{CHAPTER 4}

\section{Marital violence and the nutritional status of women and children}

This section explores the association between women's experience of physical or sexual violence perpetrated by their husband and maternal and child nutritional outcomes. Although biomedical and socio-economic risk factors for malnutrition in India are well-known, the role that marital violence plays in maternal and child anaemia and weight (being underweight) is less understood. The few studies that explored the links between marital violence and the nutritional status of women and children, reported in Tables 4.1 and 4.2, show a consistent inverse association.

\section{Nutritional status of women}

A study using NFHS-3 data explored the association between the experience of physical or sexual violence and the body mass index (BMI) of currently married women aged 15-49. Even after adjusting for such variables as age, education, residence and household wealth, a significant inverse association was observed (beta coefficient-0.20). A similar association was observed in a study using NFHS-2 data that explored the link between the experience of physical violence and such indicators as maternal anaemia and weight (being underweight). This study found that, after adjusting for a range of socio-demographic variables, the experience of more than one instance of physical violence perpetrated by a family member including the husband in the year prior to the interview was found to be strongly associated with maternal anaemia (OR 1.11), severe anaemia (OR
1.27), and being underweight (OR 1.21). In all cases, a dose-response relation was observed, with frequent and recent abuse associated with the highest probability of poor nutritional outcomes (Ackerson and Subramanian, 2008).

Findings from a third study, comprising micro-level research conducted in Karnataka among women and their children aged 6-24 months in a tribal community and a neighbouring rural community highlight, using multivariate analysis, an inverse association between the mother's experience of psychological and sexual coercion ever within marriage and her weight (Sethuraman, Lansdown and Sullivan, 2006).

\section{Nutritional status of children}

Several studies described above also explored the association between the experience of marital violence and nutritional outcomes for children and have highlighted that marital violence can severely compromise child nutrition (Table 4.2). For example, a study using NFHS-3 data observed that, even after controlling for mother's education, ruralurban residence, household wealth, birth order and presence of older same-sex siblings, sons (aged 0-35 months) of women who had experienced physical or sexual violence were significantly more likely (OR 1.17) to have been underweight than other boys; no such association was observed for daughters (Kishor and Gupta, 2009). A second study, using NFHS-2 data, also explored the links between the experience 
Table 4.1:

Association between marital violence and maternal nutrition: Findings from various studies, 1990s-2000s

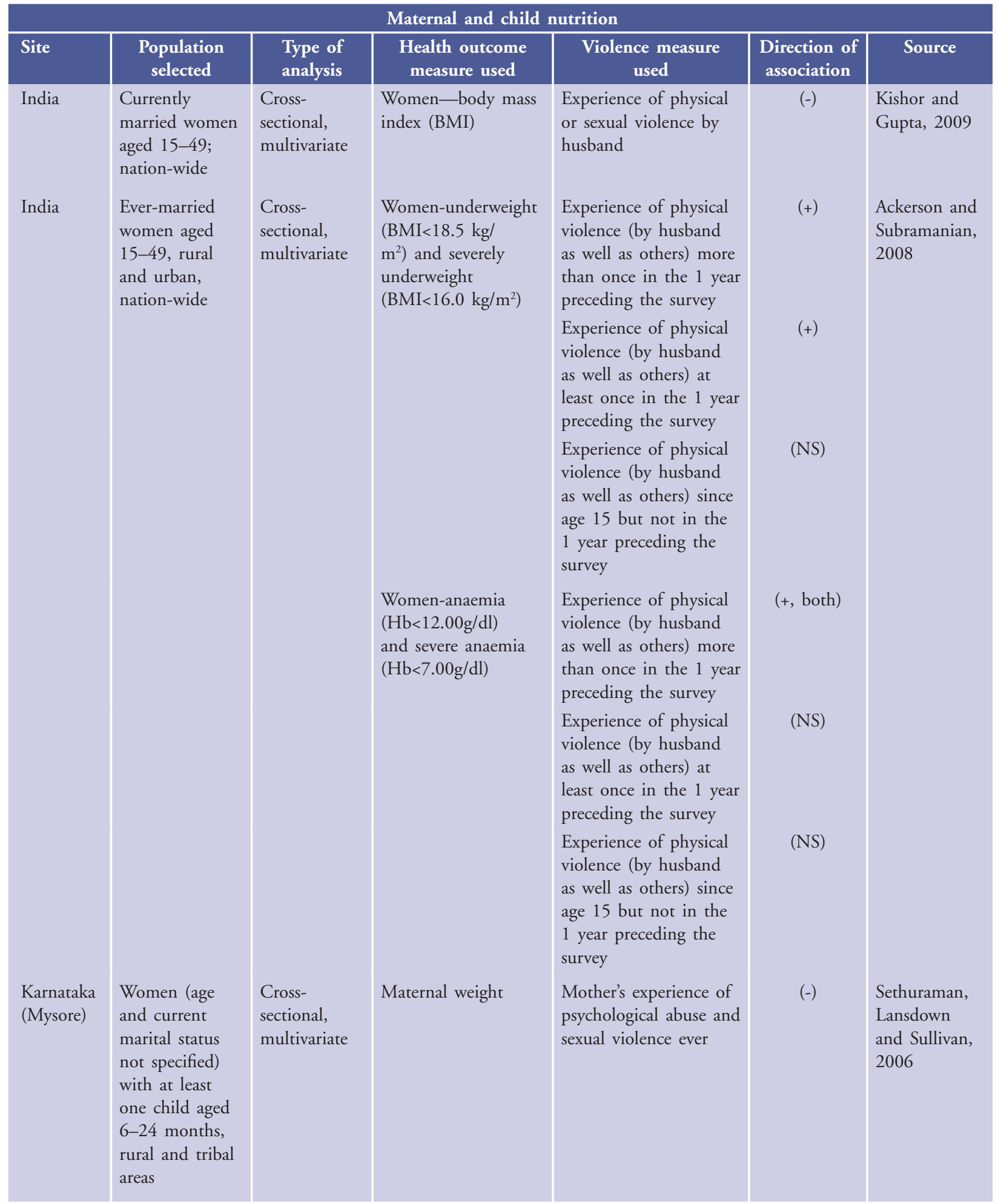

$(N S)=$ Not significant $;(+)=$ significant positive association, $p<=0.05 ;(-)=$ significant negative association, $p<=0.05$. 
Table 4.2:

Association between marital violence and child nutrition: Findings from various studies, 1990s-2000s

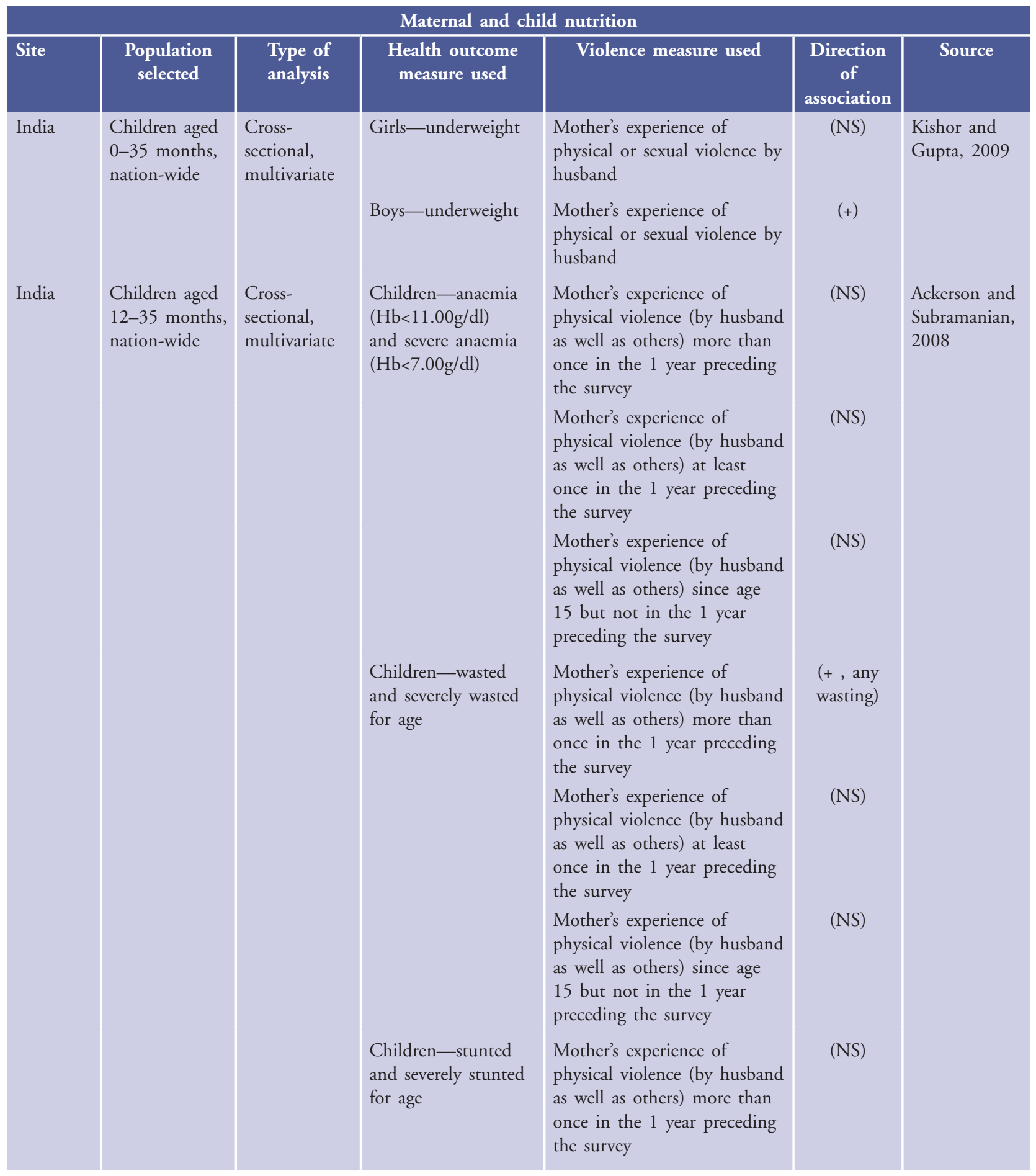




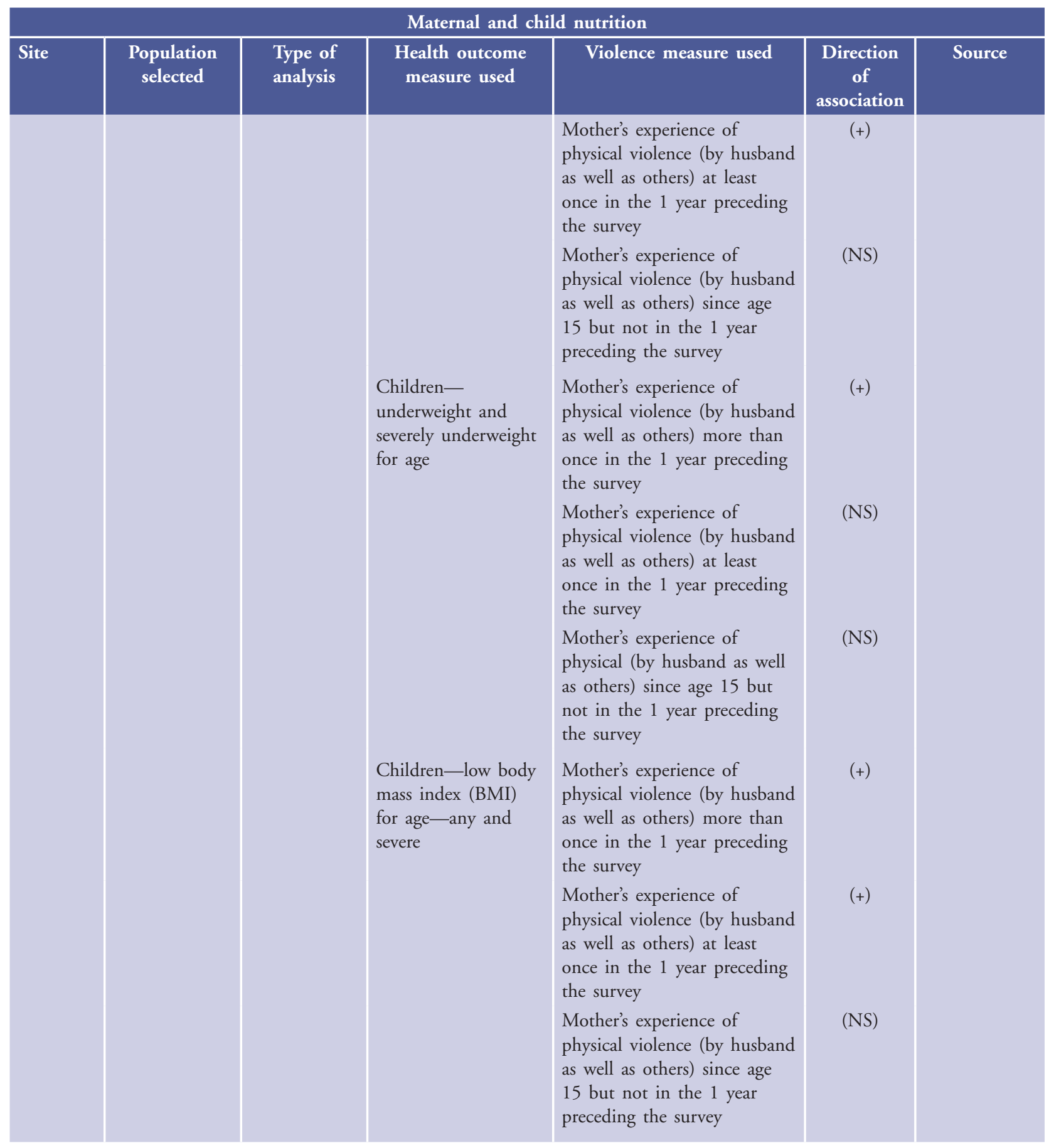

Cont'd on next page... 


\begin{tabular}{|c|c|c|c|c|c|c|}
\hline \multicolumn{7}{|c|}{ Maternal and child nutrition } \\
\hline Site & $\begin{array}{c}\text { Population } \\
\text { selected }\end{array}$ & $\begin{array}{l}\text { Type of } \\
\text { analysis }\end{array}$ & $\begin{array}{l}\text { Health outcome } \\
\text { measure used }\end{array}$ & Violence measure used & $\begin{array}{c}\text { Direction } \\
\text { of } \\
\text { association }\end{array}$ & Source \\
\hline $\begin{array}{l}\text { Karnataka } \\
\text { (Mysore) }\end{array}$ & $\begin{array}{l}\text { Children aged } \\
6-24 \text { months } \\
\text { (mother's age } \\
\text { and current } \\
\text { marital status } \\
\text { not specified), } \\
\text { rural and tribal } \\
\text { areas }\end{array}$ & $\begin{array}{l}\text { Longitudinal, } \\
\text { multivariate }\end{array}$ & $\begin{array}{l}\text { Children-weight- } \\
\text { for-age at the end of } \\
\text { a 6-month follow-up }\end{array}$ & $\begin{array}{l}\text { Mother's experience of } \\
\text { physical violence prior to } \\
\text { enrolment in the study }\end{array}$ & $(-)$ & $\begin{array}{l}\text { Sethuraman, } \\
2008\end{array}$ \\
\hline $\begin{array}{l}\text { Karnataka } \\
\text { (Mysore) }\end{array}$ & $\begin{array}{l}\text { Children aged } \\
6-24 \text { months } \\
\text { (mother's age } \\
\text { and current } \\
\text { marital status } \\
\text { not specified), } \\
\text { rural and tribal } \\
\text { areas }\end{array}$ & $\begin{array}{l}\text { Cross- } \\
\text { sectional, } \\
\text { multivariate }\end{array}$ & $\begin{array}{l}\text { Children-weight- } \\
\text { for-age }\end{array}$ & $\begin{array}{l}\text { Mother's experience of } \\
\text { psychological abuse and } \\
\text { sexual violence ever }\end{array}$ & $(-)$ & $\begin{array}{l}\text { Sethuraman, } \\
\text { Lansdown } \\
\text { and Sullivan, } \\
2006\end{array}$ \\
\hline $\begin{array}{l}\text { Karnataka } \\
(3 \\
\text { villages, } \\
\text { south } \\
\text { eastern } \\
\text { region) }\end{array}$ & $\begin{array}{l}\text { Children of } \\
\text { ever-married } \\
\text { women above } \\
\text { age } 15 \text {, potter } \\
\text { community }\end{array}$ & $\begin{array}{l}\text { Cross- } \\
\text { sectional }\end{array}$ & $\begin{array}{l}\text { Children-caloric } \\
\text { consumption }\end{array}$ & $\begin{array}{l}\text { Mother's experience of } \\
\text { physical violence ever }\end{array}$ & $(-)$ & Rao, 1998 \\
\hline
\end{tabular}

$(N S)=$ Not significant $;(+)=$ significant positive association, $p<=0.05 ;(-)=$ significant negative association, $p<=0.05$.

of physical violence and child (aged 12-35 months) malnutrition, measured by a host of anthropometric measures. Here too, after adjusting for a range of socio-demographic variables, findings show that children of mothers who had experienced domestic violence were significantly more likely than other children to experience wasting (OR 1.18), stunting (OR 1.14), being severely underweight for age

(OR 1.34), low body mass index for age (OR 1.21) and severe low body mass index for age (OR 1.50). The dose-response relation observed among women was also observed among children, with frequent and recent abuse associated with the highest probability of poor nutritional outcomes. Findings suggest that the experience of domestic violence strongly limits women's ability to make feeding decisions for their children (Ackerson and Subramanian, 2008).

Micro-level research in Karnataka also reports an inverse association between marital violence and child under-nutrition. For example, the study described above of women and their children aged 6-24 months in a tribal community and a neighbouring rural community also observed that the mother's experience of psychological and sexual violence was significantly and inversely associated with the child's weight-for-age (Sethuraman, Lansdown and Sullivan, 2006). In a second article 
from the same dataset, a longitudinal follow-up was conducted and children's nutritional status was obtained six months following the initial interview. Multivariate regression analysis was performed that included, aside from socio-demographic factors and women's experience of physical violence, anthropometric measures taken at the time of the initial interview to better reflect the influence of independent variables on changes in child growth at follow-up. Findings reiterate that the experience of violence significantly undermined a child's weight-for age (Sethuraman, 2008). In another study, also in Karnataka, it was found that if a mother had been beaten, her children obtained fewer calories than the children of other women (Rao, 1998).
Several explanations have been offered for these consistent associations between marital violence and adverse nutritional outcomes (Ackerson and Subramanian, 2008; Sethuraman, Lansdown and Sullivan, 2006). First, as a result of the psychological stress that violence induces, oxidative levels and metabolic levels are increased in the body; these are well-known risk factors for anaemia and being underweight. Second, the experience of marital violence clearly disempowers women and undermines their ability to make decisions for themselves and their children, including the choice and quantity of food, perhaps also influencing nutritional intake. And finally, where marital violence is accompanied by withholding of food, poor nutritional outcomes are bound to result. 


\section{CHAPTER 5}

\section{Marital violence and mental health consequences}

The mental health consequences of partner violence have been increasingly documented. The WHO multi-country study of violence against women observes that women who had ever experienced physical or sexual violence, or both, by a partner were significantly more likely to have ever contemplated suicide than other women, and among those who had ever contemplated suicide, were more likely to have ever attempted it. They were also significantly more likely to report recent symptoms of mental distress than women who had never experienced violence; indeed findings suggest that even past violence may be associated with recent negative mental health outcomes (Garcia-Moreno et al., 2005).

Studies conducted in India, reported in Table 5.1 and Figure 5.1, also report a direct link between marital violence and women's experience of mental health disorders. A study of women aged 15-49 in villages, urban areas and urban slums in seven settings (Bhopal, Chennai, Lucknow, Nagpur, New Delhi, Thiruvananthapuram and Vellore) conducted in 1998-99 sought to explore the links between spousal physical violence and mental health status (Kumar et al., 2005). Mental health was measured by the Self Report Questionnaire (SRQ, see Srinivasan and Suresh, 1990) standardised for Indian conditions; it includes the probing of such symptoms as generalised aches and pains, undue fatigability, weakness, insomnia, forgetfulness, and giddiness/dizziness. Findings suggest that the experience of any physically violent behaviour (slapping, hitting, kicking, beating) doubled the relative risk of poor mental health
(RR 2.2). After adjusting for socio-demographic confounding factors, the relationship remained significant (OR 2.23). Authors acknowledge that since data were drawn from a cross-sectional study, it is difficult to determine the direction of causality (Kumar et al., 2005); while it is likely that the experience of violence is a factor in explaining mental distress and attempted suicide, it is also possible that a woman's state of mental health is a significant risk factor for violence. In a qualitative study of 25 women who had experienced marital violence, women described such mental health consequences as weakness, lack of self confidence and feelings of self-worth, forgetfulness and depression; two of the 25 reported suicidal thoughts (Hamad, 2009).

Several analyses from the Goa study described earlier have observed a significant association between marital violence and mental health (Chowdhury and Patel, 2008; Maselko and Patel, 2008; Patel et al., 2006). Using cross-sectional data drawn from women aged 18-45, authors observed that even after adjusting for marital status, household size, income, debt and hunger, experience of physical and sexual violence, respectively, perpetrated by the husband at any time in married life was observed to be significantly associated with common mental disorders (CMD); even when other factorsgynaecological complaints, autonomy, violence perpetrated by others (not specified), concerns about husband's habits, support from family and so on-were controlled, sexual violence remained significantly associated with CMD (Patel et al., 2006). 
In further analysis of these data (Chowdhury and Patel, 2008), both sexual and physical violence, lifetime and recent, were found to be strongly associated with depressive disorders and attempted suicide, even after adjusting for age, economic status and literacy. Indeed, women who had experienced violence were 4-6 times more likely than others to experience depressive disorders and 3-7 times more likely to have attempted suicide. However, when longitudinal data were used, only attempted suicide remained significantly associated with experiences of sexual and physical violence, after controlling for confounding factors: those who had experienced violence were 8-11 times more likely to have attempted suicide. A third article from the same dataset shows that women who experienced verbal, physical or sexual violence perpetrated by their husband or physical violence perpetrated by others were 5 times more likely to have attempted suicide over a 12-month period, after controlling for economic adversities, social exclusion, experience of physical illness and the presence of common mental disorders at the first wave of data collection (Maselko and Patel, 2008).

A similar association was observed in a prospective follow-up study of a cohort of women aged 15-39 interviewed at the time of the NFHS-2 survey and followed-up in 2002-03 from four states (Bihar, Jharkhand, Maharashtra and Tamil Nadu). Findings suggest that even after controlling for a variety of socio-demographic factors, women who had experienced only physical violence or only sexual violence during the inter-survey period as well as women who had experienced marital violence both in the year preceding the NFHS-2 and during the inter-survey period were twice as likely as those who had not experienced marital violence at both times to report symptoms of CMD (5 or more symptoms as measured by the GHQ12). CMD among those who experienced marital violence only in the year preceding the NFHS-2 was no different than for those who had not experienced marital violence at both times (Shidhaye and Patel, 2010).

Evidence from pregnant women also indicates a link between marital violence and mental health. A study of 203 currently married women seeking antenatal care in a large obstetric centre observes a significant association between marital violence and depression, post-traumatic stress disorder (PTSD) and somatic symptoms (Varma et al., 2007). While this study did not adjust for confounding factors, it found that women experiencing physical violence reported more somatic symptoms (as assessed by the scale for assessment of somatic symptoms; Chaturvedi, Michael and Sarmukaddam, 1987), higher depression scores (as assessed by Beck's Depressions Inventory; Beck et al., 1961), significantly more PTSD symptoms (as assessed by the PTSD symptom checklist; Blanchard et al., 1996) and a lower level of life satisfaction (as assessed by the Satisfaction with Life scale; Deiner et al., 1985) than did women who did not experience physical violence. Women experiencing sexual violence within marriage also reported significantly higher levels of somatic symptoms, depression and lower levels of life satisfaction than did other women.

A prospective study of postnatal depression among 270 married women who obtained antenatal 
and delivery services in a public health facility in Goa (from the last trimester of pregnancy to 6-8 weeks and 6 months postpartum) found that $23 \%$ had postnatal depression, $13 \%$ reported marital violence, and the risk of postnatal depression among mothers who had experienced marital violence was significantly higher if the infant was a girl, but was significantly lower if the infant was a boy (RR 3.3 and 1.0, respectively). Findings confirm that genderrelated factors, including violence and son preference, were significant risk factors for postnatal depression (Patel, Rodrigues and DeSouza, 2002).

Studies conducted among special groups such as psychiatric patients also corroborate the association between experience of violence and mental health consequences. For example, in a study of female in-patients at a mental health and neuro-sciences hospital in Bangalore, women who experienced severe sexual violence (forced penetrative sexual intercourse/ rape), mostly perpetrated by their husband, were more likely than those who experienced moderate sexual violence (forced non-penetrative sexual contact/attempted rape) to experience bipolar disorder (Chandra et al., 2003). A more recent study from this hospital observed that 49\% and 39\% respectively, of women attending the adult psychiatry out-patient unit reported the experience of physical and sexual violence, and those who had experienced violence were more likely to report PTSD and depression (Chandra, Satyanarayana and Carey, 2009).

Figure 5.1: Association between marital violence and mental health outcomes

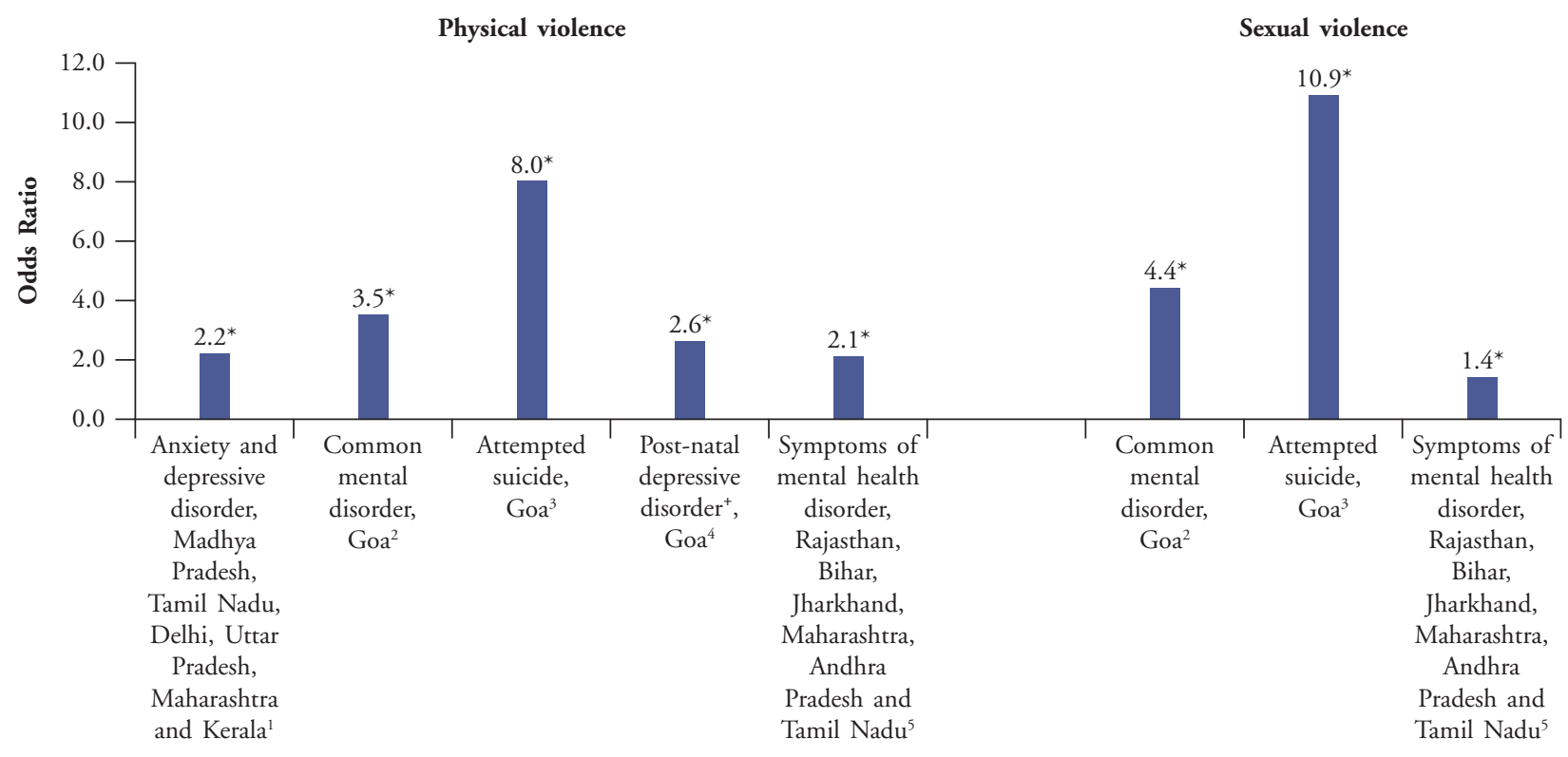

*Statistically significant at .05 level or better, after controlling for the effects of a range of socio-demographic factors. ${ }^{+}$Physical or sexual violence. Source: ${ }^{1}$ Kumar et al., 2005; ' Patel et al., 2006; ${ }^{3}$ Chowdhary and Patel, 2008; ${ }^{4}$ Patel, Rodrigues and DeSouza, 2002; ${ }^{5}$ IIPS and Population Council. 2010. 


\section{Table 5.1:}

Association between marital violence and mental health outcomes: Findings from various studies, 2000s

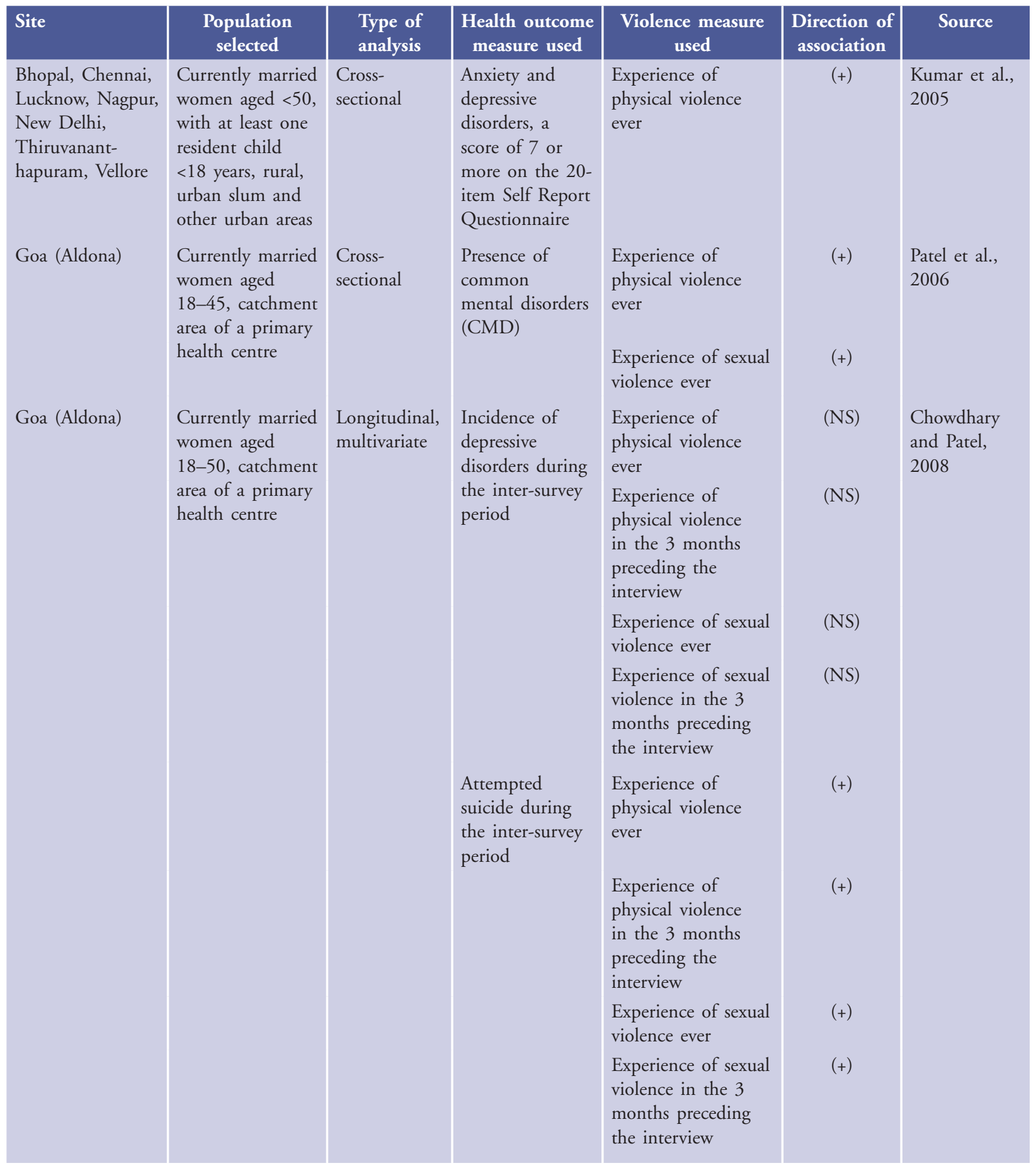


Table 5.1: (Cont'd)

\begin{tabular}{|c|c|c|c|c|c|c|}
\hline Site & $\begin{array}{l}\text { Population } \\
\text { selected }\end{array}$ & $\begin{array}{l}\text { Type of } \\
\text { analysis }\end{array}$ & $\begin{array}{l}\text { Health outcome } \\
\text { measure used }\end{array}$ & $\begin{array}{c}\text { Violence measure } \\
\text { used }\end{array}$ & $\begin{array}{l}\text { Direction of } \\
\text { association }\end{array}$ & Source \\
\hline Goa (Aldona) & $\begin{array}{l}\text { Currently married } \\
\text { women aged } \\
18-50 \text {, catchment } \\
\text { area of a primary } \\
\text { health centre }\end{array}$ & $\begin{array}{l}\text { Longitudinal, } \\
\text { multivariate }\end{array}$ & $\begin{array}{l}\text { Attempted } \\
\text { suicide over } \\
\text { a } 12 \text {-month } \\
\text { period }\end{array}$ & $\begin{array}{l}\text { Experience of } \\
\text { verbal, physical } \\
\text { or sexual violence } \\
\text { perpetrated by } \\
\text { husband or physical } \\
\text { violence perpetrated } \\
\text { by others (not } \\
\text { specified) ever }\end{array}$ & $(+)$ & $\begin{array}{l}\text { Maselko and } \\
\text { Patel, } 2008\end{array}$ \\
\hline \multirow[t]{4}{*}{$\begin{array}{l}\text { Karnataka } \\
\text { (Bangalore) }\end{array}$} & \multirow[t]{4}{*}{$\begin{array}{l}\text { Currently married } \\
\text { women aged } \\
18-49 \text { seeking } \\
\text { antenatal care in } \\
\text { a public hospital }\end{array}$} & \multirow[t]{4}{*}{$\begin{array}{l}\text { Cross- } \\
\text { sectional, bi- } \\
\text { variate }\end{array}$} & $\begin{array}{l}\text { Somatic } \\
\text { symptoms }\end{array}$ & $\begin{array}{l}\text { Experience of } \\
\text { physical violence } \\
\text { ever } \\
\text { Experience of sexual } \\
\text { violence ever }\end{array}$ & $(+)$ & $\begin{array}{l}\text { Varma et al., } \\
2007\end{array}$ \\
\hline & & & Depression & $\begin{array}{l}\text { Experience of } \\
\text { physical violence } \\
\text { ever } \\
\text { Experience of sexual } \\
\text { violence ever }^{\text {a }}\end{array}$ & $(+)$ & \\
\hline & & & $\begin{array}{l}\text { Post-traumatic } \\
\text { stress disorder } \\
\text { (PTSD) } \\
\text { symptoms }\end{array}$ & $\begin{array}{l}\text { Experience of } \\
\text { physical violence } \\
\text { ever } \\
\text { Experience of sexual } \\
\text { violence ever }\end{array}$ & NS & \\
\hline & & & Life satisfaction & $\begin{array}{l}\text { Experience of } \\
\text { physical violence } \\
\text { ever } \\
\text { Experience of sexual } \\
\text { violence ever }\end{array}$ & $(+)$ & \\
\hline Goa (Mapusa) & $\begin{array}{l}\text { Currently married } \\
\text { women (age not } \\
\text { specified) seeking } \\
\text { antenatal care in } \\
\text { the last trimester } \\
\text { of pregnancy and } \\
\text { followed up at } \\
6-8 \text { weeks and } 6 \\
\text { months following } \\
\text { delivery, tertiary } \\
\text { hospital }\end{array}$ & $\begin{array}{l}\text { Longitudinal, } \\
\text { multivariate }\end{array}$ & $\begin{array}{l}\text { Depressive } \\
\text { disorders at } \\
6-8 \text { weeks } \\
\text { postpartum, a } \\
\text { score of } 12 \text { or } \\
\text { more on the } 30 \text { - } \\
\text { item Edinburgh } \\
\text { Postnatal } \\
\text { Depression Scale }\end{array}$ & $\begin{array}{l}\text { Experience of } \\
\text { violence (not } \\
\text { specified whether } \\
\text { physical or sexual) } \\
\text { ever }\end{array}$ & $(+)$ & $\begin{array}{l}\text { Patel, } \\
\text { Rodrigues } \\
\text { and DeSouza, } \\
2002\end{array}$ \\
\hline
\end{tabular}

Cont'd on next page... 
Table 5.1: (Cont'd)

\begin{tabular}{|c|c|c|c|c|c|c|}
\hline Site & $\begin{array}{l}\text { Population } \\
\text { selected }\end{array}$ & $\begin{array}{l}\text { Type of } \\
\text { analysis }\end{array}$ & $\begin{array}{l}\text { Health outcome } \\
\text { measure used }\end{array}$ & $\begin{array}{c}\text { Violence measure } \\
\text { used }\end{array}$ & $\begin{array}{l}\text { Direction of } \\
\text { association }\end{array}$ & Source \\
\hline $\begin{array}{l}\text { Karnataka } \\
\text { (Bangalore) }\end{array}$ & $\begin{array}{l}\text { Married and } \\
\text { unmarried } \\
\text { women aged } \\
18-57 \text { ( } 94 \% \\
\text { currently married) } \\
\text { admitted for } \\
\text { treatment at a } \\
\text { mental health } \\
\text { and neuro- } \\
\text { sciences hospital }\end{array}$ & $\begin{array}{l}\text { Cross- } \\
\text { sectional }\end{array}$ & Bipolar disorder & $\begin{array}{l}\text { Severe sexual } \\
\text { violence (forced } \\
\text { penetrative sexual } \\
\text { intercourse) vs. } \\
\text { mild sexual violence } \\
\text { (unwanted non- } \\
\text { penetrative sexual } \\
\text { acts) (by husband as } \\
\text { well as others ) } \\
\text { Severe sexual } \\
\text { violence (forced } \\
\text { penetrative sexual } \\
\text { intercourse) vs. } \\
\text { mild sexual violence } \\
\text { (unwanted non- } \\
\text { penetrative sexual } \\
\text { acts) (by husband as } \\
\text { well as others) } \\
\text { Severe sexual } \\
\text { violence (forced } \\
\text { penetrative sexual } \\
\text { intercourse) vs. } \\
\text { mild sexual violence } \\
\text { (unwanted non- } \\
\text { penetrative sexual } \\
\text { acts) (by husband as } \\
\text { well as others ) }\end{array}$ & (NS) & $\begin{array}{l}\text { Chandra et } \\
\text { al. } 2003\end{array}$ \\
\hline $\begin{array}{l}\text { Karnataka } \\
\text { (Bangalore) }\end{array}$ & $\begin{array}{l}\text { Married and } \\
\text { unmarried } \\
\text { women (mean } \\
\text { age 36, 94\% } \\
\text { currently married) } \\
\text { attending a } \\
\text { mental health and } \\
\text { neuro-sciences } \\
\text { hospital and } \\
\text { experiencing non- } \\
\text { psychotic mental } \\
\text { disorder (anxiety, } \\
\text { depression, etc.) }\end{array}$ & $\begin{array}{l}\text { Cross- } \\
\text { sectional }\end{array}$ & $\begin{array}{l}\text { Depression } \\
\\
\text { Post-traumatic } \\
\text { stress disorder }\end{array}$ & $\begin{array}{l}\text { Physical and } \\
\text { psychological } \\
\text { intimate partner } \\
\text { violence (measured } \\
\text { by the index of } \\
\text { spouse abuse) } \\
\text { Sexual violence } \\
\text { (measured by the } \\
\text { sexual experience } \\
\text { scale) } \\
\text { Physical and } \\
\text { psychological } \\
\text { intimate partner } \\
\text { violence (measured } \\
\text { by the index of } \\
\text { spouse abuse) } \\
\text { Sexual violence } \\
\text { (measured by the } \\
\text { sexual experience } \\
\text { scale) }\end{array}$ & $(+)$ & $\begin{array}{l}\text { Chandra, } \\
\text { Satyanarayana } \\
\text { and Carey, } \\
2009\end{array}$ \\
\hline
\end{tabular}


Table 5.1: (Cont'd)

\begin{tabular}{|c|c|c|c|c|c|c|}
\hline Site & $\begin{array}{c}\text { Population } \\
\text { selected }\end{array}$ & $\begin{array}{l}\text { Type of } \\
\text { analysis }\end{array}$ & $\begin{array}{l}\text { Health outcome } \\
\text { measure used }\end{array}$ & $\begin{array}{c}\text { Violence measure } \\
\text { used }\end{array}$ & $\begin{array}{l}\text { Direction of } \\
\text { association }\end{array}$ & Source \\
\hline $\begin{array}{l}\text { Bihar, Jharkhand, } \\
\text { Maharashtra, } \\
\text { Tamil Nadu }\end{array}$ & $\begin{array}{l}\text { Currently married } \\
\text { women aged } \\
15-39 \text { at the } \\
\text { time of NFHS-2 } \\
(1998-99) \text { and } \\
\text { followed up in } \\
2002-03 \text {, rural, } \\
\text { state-wide }\end{array}$ & Longitudinal & $\begin{array}{l}\text { Experience of } \\
\text { symptoms of } \\
\text { mental health } \\
\text { disorders ( } 5+\text { on } \\
\text { the GHQ) }\end{array}$ & $\begin{array}{l}\text { Physical or sexual } \\
\text { violence during } \\
\text { the inter-survey } \\
\text { period and physical } \\
\text { violence in the } 12 \\
\text { months preceding } \\
\text { NFHS-2 } \\
\text { Physical or sexual } \\
\text { violence during the } \\
\text { inter-survey period } \\
\text { only } \\
\text { Physical violence } \\
\text { in the } 12 \text { months } \\
\text { preceding NFHS-2 }\end{array}$ & $(+)$ & $\begin{array}{l}\text { Shidhaye and } \\
\text { Patel, } 2010\end{array}$ \\
\hline
\end{tabular}

${ }^{a}$ Measured by the Sexual Experiences Scale (Koss and Oros, 1982).

$(N S)=$ Not significant $;(+)=$ significant positive association, $p<=0.05 ;(-)=$ significant negative association, $p<=0.05$.

Evidence from the Youth Study, presented in Table 5.2, also underscores the association between marital violence and young women's recent experience of symptoms indicative of mental health disorders. Using the General Health Questionnaire (GHQ-12), the study assessed the extent to which a

\section{Table 5.2:}

Association between marital violence experienced by currently married young women and recent experience of symptoms of mental health disorders (3+ on the GHQ): Findings from the Youth In India Situation and Needs Study ${ }^{1}$

\begin{tabular}{|c|c|c|c|c|}
\hline \multirow[t]{3}{*}{ Site } & \multicolumn{2}{|c|}{ Physical violence } & \multicolumn{2}{|c|}{ Sexual violence } \\
\hline & \multicolumn{2}{|c|}{ Odds ratios } & \multicolumn{2}{|c|}{ Odds ratios } \\
\hline & Ever experienced ${ }^{a}$ & $\begin{array}{l}\text { Experienced in last } \\
12 \text { months }^{\mathrm{b}}\end{array}$ & Ever experienced ${ }^{a}$ & $\begin{array}{c}\text { Experienced in last } \\
12 \text { months }^{\mathrm{b}}\end{array}$ \\
\hline 6 states & $2.14^{* * *}$ & $2.14^{* * *}$ & $1.42^{* * *}$ & $1.52^{* * *}$ \\
\hline Bihar & 1.54 & 1.59 & 0.68 & 0.86 \\
\hline Jharkhand & $1.87^{* * *}$ & $2.10^{* * *}$ & $1.38^{*}$ & $1.65^{* * *}$ \\
\hline Rajasthan & $2.68^{* * *}$ & $2.89^{* * *}$ & $1.52^{* * *}$ & $1.49^{* *}$ \\
\hline Maharashtra & $2.31^{* * *}$ & $2.10^{* * *}$ & $1.81^{* * *}$ & $2.79^{* * *}$ \\
\hline Andhra Pradesh & $3.31^{* * *}$ & $3.69^{* * *}$ & $2.35^{* * *}$ & $2.93^{* *}$ \\
\hline Tamil Nadu & $1.83^{* * *}$ & $1.42^{*}$ & $2.33^{* * *}$ & 1.52 \\
\hline
\end{tabular}

${ }^{a}$ Among currently married women (aged 15-24).

${ }^{b}$ Among currently married women (aged 15-24) who had cohabited for one year or more. ${ }^{*} p<=0.05 ;{ }^{* *} p<=0.01 ;{ }^{* * *} p<=0.001$.

Reference period is the month preceding the interview; GHQ: General Health Questionnaire. Source: ${ }^{1}$ IIPS and Population Council, 2010. 
respondent experienced, in the month prior to the interview, such symptoms as unhappiness, depression, anxiety and sleep disturbance, and a threshold score of 3 or more symptoms was used to identify the possible presence of mental health disorders. Evidence suggests a significant and consistent association between marital violence and symptoms of mental health disorders, irrespective of state (with the exception of Bihar), type of violence and type of measure used. Indeed, young women who had ever experienced physical violence or had experienced it in the 12 months preceding the interview were twice as likely as other women to experience symptoms suggestive of mental disorders; those who had ever or recently experienced sexual violence were 1.4-1.5 times as likely as other women to have experienced symptoms of mental disorders.
The association between marital violence and suicide is difficult to establish. A study in Delhi reveals that $56 \%$ of all suicides were committed by women, and marital discord and ill-treatment by the husband and in-laws were the most commonly reported causes (reported in Heise, Pitanguy and Germain, 1994). Likewise, a study in Bangalore among both men and women that assessed the factors correlated with suicide, using a case-control design, ${ }^{1}$ observed that the experience of domestic violence (physical, sexual or emotional) increased the odds of committing suicide by almost 7 times, and that almost three-quarters of the cases who committed suicide due to domestic violence were women (Gururaj et al., 2004).

\footnotetext{
${ }^{1}$ Information about the cases was obtained from a responsible family member using the psychological autopsy method. Controls were age-and gender-matched persons living in the same community.
} 


\section{CHAPTER 6}

\section{Marital violence and social consequences}

The social consequences of marital violence have rarely been documented in studies in India. What is available, however, provides strong evidence that the experience of marital violence is associated with a number of adverse short- and long- term behaviours, both among women themselves and their children. This section explores the association between women's experience of physical or sexual violence perpetrated by their husband and its social consequences including substance use, women's autonomy, inter-generational effects and economic costs.

\section{Substance use}

Despite an extensive search, we were not able to locate any study that explored the association between women's experience of marital violence and alcohol or drug use, and just one that explored the association between marital violence and tobacco consumption. Findings of a study using data from NFHS-2 that explored-for the first time in the developing world-the association between women's experience of violence perpetrated by any household member and tobacco consumption suggest a positive association. Compared to women who had never experienced physical violence, those who reported having been abused in the one year preceding the interview by a male household member (usually their husband) were more likely to smoke (OR 1.30; CI 1.17-1.46) and chew tobacco (OR 1.36; CI 1.28-1.44) (Ackerson et al., 2007). The authors suggest that this association results from the fact that tobacco is viewed as a convenient and low cost method for managing symptoms of stress associated with the experience of violence.

Among the surveys of youth, only the Youth Study inquired about substance use. As fewer than 1 percent of young women reported alcohol consumption or drug use, analysis was conducted only on the association between the experience of marital violence and tobacco consumption; to address issues of temporality, we restrict the analysis to tobacco consumption in the month preceding the interview. Findings, presented in Table 6.1, reiterate the findings described above when all six states are considered together: young women who had experienced violence ever or early in marriage were 1.5-1.7 times more likely than other women to report recent tobacco consumption (that is, in the month preceding the interview); in contrast, tobacco consumption was unrelated with the experience of sexual violence. Findings were by and large insignificant at the state level, with some notable exceptions: in Jharkhand and Rajasthan, young women who had experienced physical violence were 2.3-2.5 times more likely than other women to report tobacco consumption; those in Jharkhand who had experienced sexual violence were 1.6 times as likely as other women to report tobacco consumption.

\section{Women's autonomy}

Evidence on the association between women's autonomy and marital violence in India is sparse. We could locate just one study, a modelling exercise 


\section{Table 6.1:}

Association between marital violence experienced by currently married young women and recent consumption of tobacco: Findings from the Youth In India Situation and Needs Study

\begin{tabular}{|c|c|c|c|c|}
\hline \multirow[t]{3}{*}{ Site } & \multicolumn{2}{|c|}{ Physical violence } & \multicolumn{2}{|c|}{ Sexual violence } \\
\hline & \multicolumn{2}{|c|}{ Odds ratios } & \multicolumn{2}{|c|}{ Odds ratios } \\
\hline & Ever experienced ${ }^{a}$ & $\begin{array}{c}\text { Experienced in first } \\
12 \text { months of marriage }\end{array}$ & Ever experienced ${ }^{a}$ & $\begin{array}{l}\text { Experienced at } \\
\text { initiation }^{\mathrm{a}}\end{array}$ \\
\hline 6 states & $1.72^{* * *}$ & $1.54^{* *}$ & 1.15 & 1.18 \\
\hline Bihar & 1.40 & 0.50 & 0.56 & 0.80 \\
\hline Jharkhand & $2.27^{* * *}$ & $2.50^{* * *}$ & $1.59^{*}$ & $1.58^{*}$ \\
\hline Rajasthan & $2.43^{* * *}$ & 1.70 & 1.10 & 0.95 \\
\hline Maharashtra & 1.46 & 1.59 & 1.09 & 1.23 \\
\hline Andhra Pradesh & 2.83 & NC & 0.94 & $\mathrm{NC}$ \\
\hline Tamil Nadu & 2.10 & 0.99 & 1.32 & 1.57 \\
\hline
\end{tabular}

${ }^{a}$ Among currently married women (aged 15-24).

${ }^{b}$ Among currently married women (aged 15-24) who had cohabited for one year or more.

${ }^{*} p<=0.05 ;{ }^{* *} p<=0.01 ;{ }^{* * *} p<=0.001$.

Reference period is the month preceding the interview; NC: Could not be calculated as recent consumption of tobacco was not reported among those who reported violence.

Source: ${ }^{1}$ IIPS and Population Council, 2010.

using NFHS-2 data, which suggests that marital violence is significantly associated with compromised decision-making on various issues. Women who were not exposed to marital violence ware observed to have significantly more control over decisions regarding accessing health care, buying jewellery and visiting natal kin, and were more likely to have set aside money for themselves than were those who had experienced marital violence, even after controlling for a host of socio-demographic factors (Eswaran and Malhotra, 2009).

Available studies conducted among young people, reported in Table 6.2, shed light on the links between marital violence and women's autonomy and highlight that associations are not as strong or as consistently observed as those observed with various indicators of reproductive and mental health.
Indeed, while on balance, evidence suggests that the experience of marital violence-physical and sexual-is associated with diminished decisionmaking power and/or limited self-efficacy among young women, the net association is neither consistently observed, nor, in most cases, significant. Particularly noteworthy is the consistently significant inverse association observed when all six Youth Study states are considered with both indicators of agency. Associations observed at state and district levels are, however, erratic. Indeed, in some instances, including the three district study in Andhra Pradesh and Madhya Pradesh, a significant positive association was observed.

These kinds of erratic findings highlight the difficulty in establishing causality in the association between the experience of marital violence and 


\section{Table 6.2:}

Association between marital violence experienced by currently married young women and women's autonomy: Findings from various surveys, 2000s

\begin{tabular}{|c|c|c|c|c|}
\hline \multirow[t]{2}{*}{ Site } & \multicolumn{2}{|c|}{ Physical violence } & \multicolumn{2}{|c|}{ Sexual violence } \\
\hline & \multicolumn{2}{|c|}{ Odds ratios } & \multicolumn{2}{|c|}{ Odds ratios } \\
\hline \multicolumn{5}{|c|}{ Decision-making } \\
\hline & Ever experienced ${ }^{a}$ & $\begin{array}{l}\text { Experienced in first } \\
12 \text { months of marriage }\end{array}$ & Ever experienced ${ }^{\mathrm{a}}$ & $\begin{array}{l}\text { Experienced at } \\
\text { initiation }^{\mathrm{a}}\end{array}$ \\
\hline 6 states $^{1}$ & $0.84^{* * *}$ & $0.64^{* * *}$ & $0.88^{*}$ & 0.90 \\
\hline Bihar ${ }^{1}$ & 0.88 & $0.57^{* *}$ & $1.36^{*}$ & $1.52^{* *}$ \\
\hline Jharkhand $^{1}$ & $1.36^{*}$ & 1.13 & 1.25 & 1.26 \\
\hline Rajasthan $^{1}$ & 0.81 & 0.73 & $0.65^{* *}$ & $0.56^{* * *}$ \\
\hline Maharashtra $^{1}$ & 0.86 & $0.64^{*}$ & 0.85 & 0.80 \\
\hline Andhra Pradesh ${ }^{1}$ & $0.68^{*}$ & 0.64 & 0.80 & 0.96 \\
\hline Tamil Nadu ${ }^{1}$ & 0.90 & 0.98 & 0.90 & 1.10 \\
\hline $\mathrm{AP} / \mathrm{MP}^{2}$ & $1.83^{*}$ & NA & $1.58^{* * *}$ & 1.17 \\
\hline Pune district ${ }^{3}$ & $0.78^{*}$ & NA & $0.78^{*}$ & $0.76^{*}$ \\
\hline \multicolumn{5}{|c|}{ Self-efficacy } \\
\hline & Ever experienced ${ }^{a}$ & $\begin{array}{l}\text { Experienced in first } \\
12 \text { months of marriage }\end{array}$ & Ever experienced ${ }^{\mathrm{a}}$ & $\begin{array}{l}\text { Experienced at } \\
\text { initiation }^{\mathrm{a}}\end{array}$ \\
\hline 6 states $^{1}$ & $0.78^{* *}$ & $0.74^{*}$ & $0.71^{* * *}$ & $0.72^{* * *}$ \\
\hline Bihar $^{1}$ & 0.94 & 0.91 & 0.84 & 0.83 \\
\hline Jharkhand $^{1}$ & 1.00 & 0.60 & 1.07 & 1.03 \\
\hline Rajasthan ${ }^{1}$ & 0.68 & 0.64 & $1.58^{*}$ & 1.77 \\
\hline Maharashtra $^{1}$ & $0.60^{* *}$ & $0.56^{*}$ & $0.71^{*}$ & 0.73 \\
\hline Andhra Pradesh ${ }^{1}$ & 0.94 & 1.11 & $0.59^{*}$ & $0.54^{*}$ \\
\hline Tamil Nadu ${ }^{1}$ & 0.84 & 0.74 & $0.61^{* *}$ & $0.65^{*}$ \\
\hline $\mathrm{AP} / \mathrm{MP}^{2}$ & 1.18 & NA & 0.77 & $0.71^{*}$ \\
\hline Pune district ${ }^{3}$ & 0.66 & NA & 0.59 & 0.71 \\
\hline
\end{tabular}

${ }^{a}$ Among currently married women (aged 15-24).

${ }^{b}$ Among currently married women (aged 15-24) who had cohabited for one year or more. ${ }^{*} p<=0.05 ;{ }^{* *} p<=0.01 ;{ }^{* * *} p<=0.001$.

AP=Andhra Pradesh; MP=Madhya Pradesh; NA: not available, not asked.

Source: ${ }^{1}$ IIPS and Population Council, 2010; ${ }^{2}$ Santhya, Jejeebhoy and Ghosh, 2008; ${ }^{3}$ Alexander et al., 2006. 
dimensions of women's autonomy. While many suggest that the experience of marital violence is so shattering that it inhibits women from making decisions and limits their self-esteem, the reverse association is also likely, namely, that as women become more empowered and question their husband's authority or demonstrate self-efficacy, they are more likely to experience marital violence.

\section{Inter-generational effects}

Although research is limited, the experience/ perpetration of violence within marriage has a number of significant negative effects on the next generation, both during their childhood and within marriage. Short-term effects are observed with regard to child behaviours as well as morbidity. For example, it has been suggested that children who witnessed violence among their parents exhibited violent behaviour at school or in the community, and were more likely to use drugs and were more likely to commit crimes, than others (Kaur and Garg, 2008). Studies also show that mothers who experienced domestic violence were more likely than those who did not to adopt severe verbal and physical disciplinary practices with their children (Hunter et al., 2000). As far as child morbidity is concerned, a study using NFHS-3 data observes, moreover, that the risk of asthma in children under 5 was substantially higher in households where women reported marital violence in the year preceding the interview than in other households (OR 1.32); asthma is known to be closely linked with psycho-social stress and the authors argue that witnessing parental violence acts as a psychosocial stressor and thereby has an impact on the pathogenesis of asthma (Subramanian et al., 2007).
Longer-term effects are also observed. Probably the most consistent inter-generational effect observed is the link between witnessing parental violence while growing up and perpetrating it (men). Among studies focused on men, a recent analysis of NFHS-3 data reports, for example, that men whose mother had ever been beaten by their father were considerably more likely than other men to have perpetrated physical or sexual violence on their wife (44\% versus 33\%) (Kishor and Gupta, 2009). Similar findings were obtained in a multivariate analysis of men in an urban slum of Mumbai; findings suggest that having witnessed parental violence in childhood was a strong predictor of perpetration of marital violence in the year preceding the interview, even after controlling for socio-demographic factors as well as sexual health problems, substance use and gambling (Verma and Collumbien, 2003). A study of men in Uttar Pradesh, using the PERFORM data set, observed that compared to men raised in nonviolent homes, men from violent homes were both significantly more likely to believe in the husband's right to control his wife and to be physically and sexually abusive toward their own wife, with about a third of wife abuse in this generation attributable to witnessing parental violence (Martin et al., 2002). A more recent study using the same (PERFORM) data set reiterates this finding; even after controlling for socio-demographic factors, household economic status and economic pressure, husband's experience of extramarital relations, and such contextual, community level indicators as the economic situation of the community, norms relating to gender roles and wifebeating and district murder rates, inter-generational exposure to violence remained significantly associated with the recent perpetration of physical and sexual 
violence. Compared to men who had not witnessed parental violence, those who had witnessed their father beating their mother were 4.7 times more likely to physically beat their wife and 3 times more likely to sexually coerce their wife (Koenig et al., 2006). Indeed, it appears that witnessing parental violence while growing up leads to accepting violence within marriage as normative behaviour, as revealed in an analysis of NFHS-3 data covering over 18,047 men who reported childhood exposure to parental violence; among these men, two-thirds justified wifebeating for one or more reasons (Zhu and Dalal, 2010), compared to $51 \%$ among all men as reported in NFHS-3 (IIPS and Macro International, 2007).

Evidence suggests, correspondingly, that women who had witnessed violence while growing up were more likely than other women to experience violence in their marital life. A recent analysis of NFHS-3 data reports, for example, that even after adjusting for a host of socio-demographic characteristics, the effect of having a mother who was beaten by the father on a woman's risk of experiencing physical or sexual violence remained strong and significant. Women whose father had beaten their mother were 2-3 times more likely than those who did not report that their father had beaten their mother to have experienced physical or sexual violence (adjusted OR 2.89 and 2.03, respectively); they were also significantly more likely to have experienced emotional violence (adjusted OR 2.37) (Kishor and Gupta, 2009). Likewise, a study of almost 10,000 women from seven settings throughout India reports that women who witnessed their father beating their mother were at increased risk of experiencing physical violence within marriage (adjusted OR 1.9) even after controlling for such factors as rural-urban residence, socio-economic factors, social support and husband's alcohol consumption (Jeyaseelan et al., 2007). Also, a study of women in an urban slum of Mumbai observes that having witnessed parental violence in childhood was a strong predictor of experience of marital violence in the year preceding the interview, even after controlling for socio-demographic factors, husband's sexual health problems and dissatisfaction with dowry (Verma and Collumbien, 2003).

Findings from surveys focused on youth are presented in Tables 6.3 and 6.4. Evidence from the Youth Study shows a remarkably strong and consistent relationship between women having witnessed violence among parents (father beating mother) while growing up and the experience of physical violence ever in married life as well as in the first year of married life. Indeed, this association was observed in each of the six states as well as in the Pune district study. In general, findings suggest that young women who had witnessed parental violence were almost three times more likely than other women to experience violence in married life. The association between witnessing parental violence and experience of sexual violence was not observed when all Youth Study states were considered together; however, a significant association was observed in five of the six Youth Study states as well as in the Pune district study.

Evidence presented in Table 6.4 also confirms that young men who witnessed their 
Table 6.3:

Association between marital violence experienced by currently married young women and witnessing parental violence when growing up: Findings from various surveys, 2000s

\begin{tabular}{|c|c|c|c|c|}
\hline \multirow[t]{3}{*}{ Site } & \multicolumn{2}{|c|}{ Physical violence } & \multicolumn{2}{|c|}{ Sexual violence } \\
\hline & \multicolumn{2}{|c|}{ Odds ratios } & \multicolumn{2}{|c|}{ Odds ratios } \\
\hline & Ever experienced $^{a}$ & $\begin{array}{c}\text { Experienced in first } \\
12 \text { months of marriage }\end{array}$ & Ever experienced $^{\mathrm{a}}$ & $\begin{array}{l}\text { Experienced at } \\
\text { initiation }^{\mathrm{a}}\end{array}$ \\
\hline 6 states $^{1}$ & $2.78^{* * *}$ & $2.57^{* * *}$ & 1.08 & 0.96 \\
\hline Bihar $^{1}$ & $2.45^{* * *}$ & $1.72^{*}$ & 0.88 & 0.85 \\
\hline Jharkhand $^{1}$ & $2.08^{* * *}$ & $1.96^{* * *}$ & $1.91^{* * *}$ & $1.81^{* * *}$ \\
\hline Rajasthan $^{1}$ & $5.12^{* * *}$ & $3.60^{* * *}$ & $1.48^{* *}$ & 1.06 \\
\hline Maharashtra $^{1}$ & $3.13^{* * *}$ & $3.66^{* * *}$ & $1.80^{* * *}$ & $1.78^{* * *}$ \\
\hline Andhra Pradesh ${ }^{1}$ & $2.34^{* * *}$ & $2.20^{* * *}$ & $1.61^{* *}$ & $1.98^{* *}$ \\
\hline Tamil Nadu ${ }^{1}$ & $2.50^{* * *}$ & $2.31^{* * *}$ & $1.63^{* * *}$ & 1.24 \\
\hline Pune district ${ }^{2}$ & $3.03^{* * *}$ & NA & $1.62^{* * *}$ & $1.37^{*}$ \\
\hline
\end{tabular}

"Among currently married women (aged 15-24).

${ }^{b}$ Among currently married women (aged 15-24) who had cohabited for one year or more.

${ }^{*} p<=0.05 ;{ }^{* *} p<=0.01 ;{ }^{* * *} p<=0.001$.

NA: not available, not asked.

Source: ${ }^{1}$ IIPS and Population Council, 2010; ${ }^{2}$ Alexander et al., 2006.

father perpetrating violence on their mother were themselves far more likely than other young men to perpetrate violence-both physical and sexual —on their wife. Indeed, Youth Study findings show quite consistently that young men who had witnessed parental violence were 2-3 times more likely than other young men to perpetrate physical violence, and about twice as likely to perpetrate sexual violence, on their wife. As in the case of young women, findings were remarkably consistent. Associations with both measures of physical violence were significant in all six states. With regard to sexual violence, young men who had witnessed their father perpetrating violence on their mother were significantly more likely than other young men to have ever perpetrated violence on their wife in five of the six Youth Study states (excluding Jharkhand) as well as in the Pune district study; they were more likely to have perpetrated sexual violence on their wife at initiation in just two states (Rajasthan and Andhra Pradesh) and in Pune district.

\section{Economic costs}

The direct economic costs of violence include loss of income, loss of productivity, cost of health care, cost of housing and cost of social services. A study in Nagpur collected information on loss of workdays (including housework) for the woman; loss of workdays for the husband; decline in total income; and health care expenditure due to violence experienced. In this site, $38 \%$ of women 


\section{Table 6.4:}

Association between marital violence perpetrated by currently married young men and witnessing parental violence when growing up: Findings from various surveys, 2000s

\begin{tabular}{|c|c|c|c|c|}
\hline \multirow[t]{3}{*}{ Site } & \multicolumn{2}{|c|}{ Physical violence } & \multicolumn{2}{|c|}{ Sexual violence } \\
\hline & \multicolumn{2}{|c|}{ Odds ratios } & \multicolumn{2}{|c|}{ Odds ratios } \\
\hline & Ever perpetrated ${ }^{a}$ & $\begin{array}{c}\text { Perpetrated in first } \\
12 \text { months of marriage }\end{array}$ & Ever perpetrated ${ }^{a}$ & $\begin{array}{l}\text { Perpetrated at } \\
\text { initiation }^{\mathrm{a}}\end{array}$ \\
\hline 6 states $^{1}$ & $2.67^{* * *}$ & $2.40^{* * *}$ & $1.96^{* * *}$ & $1.72^{* * *}$ \\
\hline Bihar $^{1}$ & $2.62^{* * *}$ & $2.24^{*}$ & $1.79^{* *}$ & 1.19 \\
\hline Jharkhand ${ }^{1}$ & $1.82^{* *}$ & $2.28^{* *}$ & 1.37 & 1.30 \\
\hline Rajasthan $^{1}$ & $3.58^{* * *}$ & $3.52^{* * *}$ & $2.79^{* * *}$ & $3.31^{* * *}$ \\
\hline Maharashtra $^{1}$ & $3.06^{* * *}$ & $2.20^{* * *}$ & $2.23^{* * *}$ & 1.64 \\
\hline Andhra Pradesh ${ }^{1}$ & $3.35^{* * *}$ & $2.98^{* * *}$ & $3.10^{* * *}$ & $3.96^{* * *}$ \\
\hline Tamil Nadu ${ }^{1}$ & $1.62^{* * *}$ & $1.39^{*}$ & $1.40^{*}$ & 1.09 \\
\hline Pune district ${ }^{2, \mathrm{c}}$ & 2.15 & NA & $1.96^{*}$ & $1.89^{*}$ \\
\hline
\end{tabular}

${ }^{a}$ Among currently married men (aged 15-29).

${ }^{b}$ Among currently married men (aged 15-29) who had cohabited for one year or more.

'Among currently married men (aged 15-24).

${ }^{*} p<=0.05 ;{ }^{* *} p<=0.01 ;{ }^{* * *} p<=0.001$.

NA: not available, not asked.

Source: ${ }^{1} I I P S$ and Population Council, 2010; ${ }^{2}$ Alexander et al., 2006.

had experienced physical violence and 15\% had experienced sexual violence within marriage; $9 \%$ $(\mathrm{N}=116)$ reported injuries due to violence in the last year. Findings suggest that of the 91 women who reported that they had missed work and/or housework, 35 had missed wage earning work and 83 had missed housework: an average of 7 days each of wage work and housework, were missed. In addition, $42 \%$ of the women who reported an injury reported that their husband had also missed work after an incident of violence. Authors estimate, on the basis of reported wages, that loss of income from wage work was, on average, Rs 759 per incident, and when the cost of housework forgone is included, a total of Rs 974 per incident of violence. In addition, 57 women reported health care costs, averaging Rs 1,084 per incident, with a range of Rs 10-20,000 (ICRW, 2000). 


\section{CHAPTER 7}

\section{Way forward}

This review highlights the pervasiveness of both physical and sexual violence within marriage in India, and reiterates the adverse health and social consequences of marital violence among women in general and young women in particular. Most consistently observed were findings of a significant and consistent association between the experience of violence and such outcomes as unintended pregnancy, pregnancy-related care, foetal and infant mortality, symptoms of RTI/STI, and mental health disorders. These associations are observed, moreover, from an early age, suggesting that women are at risk of ill-health from early married life. Findings suggest several priority programmatic areas for action as well as themes and issues requiring research attention.

While this report has focused on the consequences of marital violence, its most obvious recommendation is to strengthen efforts to prevent the incidence of marital violence. Prevention initiatives must be multipronged. Activities are needed that empower women, provide them the skills, resources and opportunities to recognise risk situations and protect themselves from violence, and build life-skills from a young age. Communication skills among couples must be fostered and the need for exploring non-violent means of conflict resolution and developing egalitarian marital relationships must be highlighted. At the same time efforts must be made at the community level, among both men and women, to raise awareness of the adverse consequences of marital violence and to reduce the community's tolerance of such acts. Special attention must be paid to change deeply- entrenched inegalitarian gender norms. New norms of masculinity and femininity must be fostered. Further, norms that inhibit community members from intervening in incidents of marital violence must be changed. There is also a need to promote awareness and enforcement of laws protecting women from domestic violence.

At the same time, there is also a need to address the multiple health and social consequences of violence highlighted in this report and a top priority is to screen, identify and refer women who experience marital violence. Several manuals exist that guide providers on raising the subject of abuse with women in non-judgemental ways. For example, UNFPA has developed a guide for health care providers and managers that outlines the steps involved in integrating services to address genderbased violence into health programmes: given the sensitive nature of this issue, the guide stresses the need to provide routine screening in a confidential setting (Stevens, 2001). So too, the WHO recommends that service providers integrate questions regarding domestic violence into routine historytaking, and offer emotional and medical support to women experiencing domestic violence (WHO, 1997). Service protocols could include violence screening while recording the regular history of women seeking health care services. Screening tools will help providers bring up the subject of abuse in non-judgemental ways; by following a short set of questions, providers may be able to ask clients about current and past experiences with abuse; where these tools have been used, they have not only increased 
the detection of violence among clients (UNFPA, 2010; GMC and Population Council, 2002; Khosla et al., 2005; Muthal-Rathore, Tripathi and Arora, 2002; Purwar et al., 1999), but also were acceptable to providers. Screening activities must include recording a complete history of marital violence with details of the most recent and earlier episodes of violence; screening should also include a physical examination, and treatment or referral if necessary. A system to maintain follow-up contact with women who report the experience of marital violence would also need to be put in place.

Screening activities must be provided in a wide range of services. Women seeking care for adverse health consequences of marital violence may seek a number of services and it would be appropriate to establish screening mechanisms in all such services. For example, the immediate physical consequences of marital violence-abdominal/thoracic injuries, lacerations, fractures and burns-call for screening activities in emergency (casualty) services in general, as well as burns and orthopaedic-related centres.

As most women visit a health centre at some point in their life for reproductive and child health services, these centres could serve as an important focal point to identify women who experience marital violence. Our findings, showing a strong link between marital violence and RTI/STI/HIV and unmet need for contraception, call for the integration of violence screening in all sexual and reproductive health services, including family planning, ICTC and other HIV-related services. Likewise, the evidence presented in this review points to the need to address the issue of domestic violence in safe motherhood and child survival programmes as findings from several studies suggest that pregnancy-related care seeking could be enhanced, and a large proportion of foetal and neonatal deaths could be prevented if the incidence of marital violence is reduced. Also, notable is the link between marital violence and malnutrition among women and their children. Programmes aimed at improving the nutritional status of women and children must take note of these findings; Integrated Child Development Services (ICDS) workers who play a key role in such programmes should be made aware of this link, and trained to support women experiencing marital violence. Moreover, findings highlighting the links between marital violence and adverse mental health outcomes emphasise that the National Mental Health Programme must incorporate a special focus on identifying and treating women who experience marital violence.

Women who have experienced marital violence and attend a particular service may have other health needs as well that the first point of contact is not equipped to address. It is important, therefore, that appropriate referral chains are established. While referrals could be recommended by the primary provider, appropriate mechanisms would also need to be established to ensure that abused women follow-up on these referrals. Given that many abused women may not follow-up on referrals recommended by their primary provider, sensitive outreach activities must be included that support women to access these services. In addition, there is a need to provide referrals to services outside the health arena, for example, legal support, shelter and so on. 
To effectively meet the needs of abused women at the health facility level, provider-level barriers must be addressed. Key barriers include providers' lack of training on eliciting information and counselling women on gender-based violence, lack of time to provide related services, and providers' discomfort in communicating on the sensitive issue of marital violence with women. Indeed, provider inhibitions reflect societal norms that marital violence is "normal" and a family affair, and that providers should not intervene in domestic matters. It is important therefore that providers are given the skills needed to assist abused women. Training is needed to strengthen providers' ability to probe these issues sensitively, refer women appropriately and maintain women's confidentiality; at the same time, efforts must be made to change provider attitudes about the acceptability of marital violence. Finally, health care providers must be made aware of the laws surrounding violence against women and the sources of support available to women from sectors other than health (access to the police, the legal system, shelter, and NGOs, for example).

Findings also suggest that there is a need for further research on several issues related to marital violence. Most studies, with the exception of those using a longitudinal design, are unable to establish causality between martial violence and adverse health and social outcomes given their reliance on crosssectional data. There is a need for more longitudinal studies, or at least cross-sectional studies that are better equipped to provide histories of both violence as well as reproductive health outcomes.

While there is a growing body of evidence on associations between physical and sexual violence and health and social consequences for women, evidence remains sparse with regard to the effects of emotional violence or the threat of violence on women's health and wellbeing. Research is needed that explores these links, and notably explores the links of emotional violence and threats on women's mental health, their health care practices and care seeking behaviours, and their autonomy.

While the associations between the experience of violence and adverse outcomes are apparent, what is less clear are the pathways through which these associations take place. There is a need for research, both quantitative and qualitative, that traces these links - for example, between the experience of marital violence and infant mortality, or the unmet need for contraception, or adverse outcomes in the next generation.

At the health system level, further research is needed that explores provider attitudes and provider practices in terms of screening, counselling and treating women who have experienced marital violence. At the same time, research is required to estimate the cost of caring for women who experience adverse consequences of violence. 


\section{References}

Acharya, R. and S. J. Jejeebhoy. 2008. Adverse Health Outcomes of Physical and Sexual Violence within Marriage: Experiences of Young Women in Maharashtra, India. Paper presented at the Conference "Lessons learned and future challenges in the Reproductive Health Program," 28-29 February. New Delhi.

Ackerson, L. K., I. Kawachi, E. M. Barbeau et al. 2007. "Exposure to domestic violence associated with adult smoking in India: A population based study," Tobacco Control, 16:378-383.

Ackerson, L. K. and S. V. Subramanian. 2008. "Domestic violence and chronic malnutrition among women and children in India," American Journal of Epidemiology, 167:1188-1196.

Ackerson, L. K. and S. V. Subramanian. 2009. "Intimate partner violence and death among infants and children in India," Pediatrics, 124(5):e878-e889.

Agarwal, N., D. Kumar, H. M. Swami et al. 2009. "Correlates of gender-based physical violence in peri-urban area of Chandigarh. India," Internet Journal of Health, 9(1).

Ahmed, S., M. A. Koenig and R. Stephenson. 2006. "Effects of domestic violence on perinatal and early childhood mortality: Evidence from North India," American Journal of Public Health, 96(8):1423-1428.

Alexander, M., L. Garda, S. Kanade et al. 2006. Formation of Partnerships among Young Women and Men in Pune District, India. New Delhi: Population Council.

Audinarayana, N. 2005. Does Domestic Violence Influence Reproductive Health of Women: An Examination of the NFHS 1998-99 Data for Bihar and Tamil Nadu. In B. Donta, K.M. Vogelsong, P.F.A. Van Look, C.P. Puri (Eds). Enhancing Male Partnership in Sexual and Reproductive Health, Mumbai, National Institute for Research in Reproductive Health, pp. 365-382.

Babu, V. B and S. K. Kar. 2009. "Domestic violence against women in eastern India: A population-based study on prevalence and related issues," BMC Public Health, 9:129.

Beck, A. T., C. H. Ward, M. Mendelsohn et al. 1961. "An inventory for measuring depression," Archives General Psychiatry, 4:561-571.

Blanchard, F. B., J. Jones-Alexander, T. C. Buckley et al. 1996. "Psychometric properties of the PTSD Checklist (PCL)," Behaviour Research Therapy, 34:669-673.

Chandra, P. S., S. D. Varma, M. P. Carey et al. 2003. "A cry from the darkness: Women with severe mental illness in India reveal their experiences with sexual coercion," Psychiatry, 66(4):323-334.

Chandra, P. S., V. A. Satyanarayana and M. P. Carey. 2009. "Women reporting intimate partner violence in India: Associations with PTSD and depressive symptoms," Archives of Women's Mental Health, 12(4):203-209.

Chandrasekaran, V., K. Krupp, R. George et al. 2007. "Determinants of domestic violence among women attending an HIV voluntary counselling and testing centre in Bangalore, India," Indian Journal of Medical Science, 61:253-262. 
Chaturvedi, S. K., A. Michael and S. Sarmukaddam. 1987. "Somatisers in psychiatric care," Indian Journal of Psychiatry, 29:337-342.

Chhabra, S. 2007. "Physical violence during pregnancy," Journal of Obstetrics and Gynaecology, 27(5):460-463.

Chhabra, S. 2008. "Sexual violence among pregnant women in India," Journal of Obstetrics and Gynaecology, $34(2): 238-241$.

Chowdhary, N. and V. Patel. 2008. "The effect of spousal violence on women's health: Findings from the Stree Arogya Shodh in Goa, India," Journal of Postgraduate Medicine, 54(4):306-312.

Decker, M. R., G. R Seage, D. Hemenway et al. 2009. "Intimate partner violence functions as both a risk marker and risk factor for women's HIV infection: Findings from Indian husband-wife dyads," Journal of Acquired Immune Deficiency Syndromes, 51(5):593-600.

Deiner, E., R. A. Emmons, R. J. Larsen et al. 1985. "The satisfaction with life scale," Journal of Personal Assessment, 49:71-75.

Eswaran, M. and N. Malhotra. 2009. "Domestic violence and women's autonomy: Evidence from India" (unpublished). http://works.bepress.com/nisha_malhotra/14.

Ganatra, B. R., K. J. Coyaji and V.N. Rao.1998. “Too far, too little, too late: A community-based case-control study of maternal mrotaltiy in rural west Maharashtra, India," Bulletin of the World Health Organization: 76(6):591-598.

Garcia-Moreno, C., H. Jansen, M. Ellsberg et al. 2005. WHO Multi-Country Study on Women's Health and Domestic Violence against Women: Initial Results on Prevalence, Health Outcomes and Women's Responses. Geneva: World Health Organization.

Garcia-Moreno, C., H. Jansen, M. Ellsberg et al. 2006. "Prevalence of intimate partner violence: findings from the WHO multi-country study on women's health and domestic violence," Lancet, 368:1260-1269.

Go, V.F., S. C. Johnson, M. E. Bentley et al. 2003. "When HIV-prevention messages and gender norms clash: The impact of domestic violence on women's HIV risk in slums of Chennai, India," AIDS and Behavior, $7(3): 263-272$.

Government Medical College (GMC) and Population Council. 2002. "Feasibility for introducing abuse assessment screen in antenatal care in hospitals." Final report (unpublished).

Gururaj, G., M. K. Isaac, D. K. Subbakrishna et al. 2004. "Risk factors for completed suicides: A case-control study from Bangalore, India," International Journal of Injury Control and Safety Promotion, 11(3):183-191.

Hamad, N. B. 2009. "Exploring the health care needs of women who experience violence in Uttar Pradesh, India." Dissertation submitted to the University of Liverpool, Liverpool School of Tropical Medicine, UK. (unpublished)

Heise, L. L., K. Moore and N. Toubia. 1995. Sexual Coercion and Reproductive Health: A Focus on Research. New York: Population Council. 
Heise, L. L., J. Pitanguy and A. Germain. 1994. Violence against Women: The Hidden Health Burden. World Bank Discussion Paper, 255. Washington, D.C.: World Bank.

Hindin, M. J., S. Kishor and D. L. Ansara. 2008. "Intimate Partner Violence among Couples in 10 DHS Countries: Predictors and Health Outcomes." DHS Analytical Studies No. 18. Calverton, Maryland, USA: Macro International Inc.

Hunter, W. M., D. Jain, L. S. Sadowski et al. 2000. "Risk factors for severe child discipline practices in rural India," Journal of Pediatric Psychology, 25(6):435-447.

International Centre for Research on Women (ICRW). 2000. "Domestic Violence in India: A Summary Report of a Multi-Site Household Survey" (vol. 3). Washington, D.C.: ICRW.

International Institute for Population Sciences (IIPS) and Macro International. 2007. National Family Health Survey (NFHS-3), 2005-06: India, Volume 1. Mumbai: IIPS.

International Institute for Population Sciences (IIPS) and Population Council. 2010. Youth in India: Situation and Needs 2006-2007. Mumbai: IIPS.

Jain, D., S. Sanon, L. Sadowski et.al. 2004. "Violence against women in India: Evidence from rural Maharashtra, India," Rural Remote Health, 4(4):304.

Jain, D. L., S. N. Ughade, L. Sadowski et al. 2005. "Physical Abuse and Adverse Pregnancy Outcome: A Cohort Study." Presentation made at Forum 9, Mumbai, 12-16 September.

Jejeebhoy, S. J. 1998a. “Wife-beating in rural India: A husband's right?” Economic and Political Weekly, 33(15):855-862.

Jejeebhoy, S. J. 1998b. "Associations between wife-beating and foetal and infant death: Impressions from a survey in rural India," Studies in Family Planning, 29(3):300-308.

Jeyaseelan, L., S. Kumar, N. Neelakantan et al. 2007. "Physical spousal violence against women in India: Some risk factors," Journal of Biosocial Science, 39(5):657-670.

Johnson, N. and M. Sengupta. 2008. "Do battered mothers have more feotal and infant deaths? Evidence from India," PSC Research Report No.08-634.

Kaur, R and S. Garg. 2008. "Addressing domestic violence against women: An unfinished agenda," Indian Journal of Community Medicine, 33(2):73-76.

Khan, M. E., J. W. Townsend, R. Sinha et al. 1996. “Sexual violence within marriage," Seminar, 447:32-35.

Khosla, A. H., D. Dua, L. Devi et al. 2005. "Domestic violence in pregnancy in North Indian women," Indian Journal of Medical Sciences, 59(5):195-199.

Kishor, S. and K. Gupta. 2009. Gender Equality and Women's Empowerment n India. National Family Health Survey (NFHS-3), India, 2005-06. Mumbai: International Institute for Population Sciences; Calverton, Maryland, USA: ICF Macro. 
Kishor, S and K. Johnson. 2004. Profiling Domestic Violence: A Multi-Country Study. Calverton, Maryland: ORC Macro.

Koenig, M. A., R. Stephenson, R. Acharya et al. 2010. "Domestic violence and early childhood mortality in rural India: Evidence from prospective data," International Journal of Epidemiology, 39(3):825-833.

Koenig, M. A., R. Stephenson, S. Ahmed et al. 2006. "Individual and contextual determinants of domestic violence in north India," American Journal of Public Health, 96(1):132-138.

Koski, A., R. Stephenson and M. Koenig. 2010. "Physical partner violence during pregnancy and use of prenatal care in rural India." (Unpublished).

Koss, M. P. and C. J. Oros. 1982. "Sexual experiences survey: a research instrument investigating sexual aggression and victimization," Journal of Consulting and Clinical Psychology, 50:455-457.

Krishnan, S. 2005. "Gender, caste, and economic inequalities and marital violence in rural south India," Health Care for Women International, 26(1):87-99.

Krug, E. G., L. L. Dalhberg, J. A. Mercy et al. 2002. World Report on Violence and Health. Geneva: World Health Organization.

Kumar, S., L. Jeyaseelan, S. Suresh et al. 2005. "Domestic violence and its mental health correlates in Indian women," British Journal of Psychiatry, 187:62-67.

Martin, S., B. Kilgallen, A. O. Tsui et al. 1999. "Sexual behaviors and reproductive health outcomes: Associations with wife abuse in India," Journal of the American Medical Association, 282(20):1967-1972.

Martin, S., K. E. Moracco, J. Garro et al. 2002. "Domestic violence across generations: Findings from northern India," International Journal of Epidemiology, 31:560-572.

Maselko, J. and V. Patel. 2008. "Why women attempt suicide: The role of mental illness and social disadvantage in a community cohort study in India," Journal of Epidemiology and Community Health, 62:817-822.

Monemi, K. A. 2008. The Impact of Violence Against Women on Child Growth, Morbidity and Survival: Studies in Bangladesh and Nicaragua. Digital Comprehensive Summaries of Uppsala Dissertations from the Faculty of Medicine 366, Uppsala University.

Muthal-Rathore, A., R. Tripathi and R. Arora. 2002. "Domestic violence against pregnant women interviewed at a hospital in New Delhi," International Journal of Gynecology and Obstetrics, 76(1):83-85.

Panda, P. and B. Agarwal. 2005. "Marital violence, human development and women's property status in India," World Development, 33(5):823-850.

Pandey, G. K., D. Dutt and B. Banerjee. 2009. Partner and relationship factors in domestic violence: Perspectives of women from a slum in Calcutta, India. Journal of Interpersonal Violence, 24(7):1176-1191. 
Patel, V., M. Rodrigues and N. DeSouza. 2002. "Gender, poverty, and postnatal depression: A study of mothers in Goa, India," American Journal of Psychiatry, 159:43-47.

Patel, V., H. A. Weiss, D. Mabey et al. 2006. "The burden and determinants of reproductive tract infections in India: A population based study of women in Goa, India," Sexual Transmitted Infection, 82:243-249.

Peedicayil, A., L. S. Sadowski, L. Jeyaseelan et al. 2004. "Spousal physical violence against women during pregnancy," International Journal of Obstetrics and Gynaecology, 111(7):682-687.

Purwar, M. B., L. Jeyaseelan, U. Varhadpande et al. 1999. "Survey of physical abuse during pregnancy in GMCH, Nagpur, India," Journal of Obstetrics and Gynaecology Research, 25 (3):165-171.

Rao, V. 1998. Domestic violence and intra-household resource allocation in rural India: An exercise in participatory econometrics. In M. Krishnaraj, R. Sudarshan, A. Sharif (eds.), Gender, Population, and Development. Oxford and Delhi: Oxford University Press.

Ravindran, T.S and P. Balasubramanian. 2004. "'Yes' to abortion but 'no' to sexual rights: The paradoxical reality of married women in rural Tamil Nadu, India," Reproductive Health Matters, 12(23):88-99.

Rocca, C. H., S. Rathod, T. Falle et al. 2009. "Challenging assumptions about women's empowerment: Social and economic resources and domestic violence among young married women in urban south India," International Journal of Epidemiology, 38(2):577-585.

Santhya, K. G., S. J. Jejeebhoy and S. Ghosh. 2008. Early Marriage and Sexual and Reproductive Health Risks: Experiences of Young Women and Men in Andhra Pradesh and Madhya Pradesh, India. New Delhi: Population Council.

Sethuraman, K. 2008. The Role of Women's Empowerment and Domestic Violence in Child Growth and Undernutrition in a Tribal and Rural Community in South India. UNU/WIDER- Research paper, United Nations University, World Institute for Development Economics Research, 2008/15.

Sethuraman K., R. Lansdown and K. Sullivan. 2006. "Women's empowerment and domestic violence: The role of socio-cultural determinants in maternal and child under-nutrition in tribal and rural communities in South India," Food Nutrition Bulletin, 27:12-143.

Shidhaye, R. and V. Patel. 2010. "Gender disadvantage and common mental disorders in women: A population based longitudinal study of 5703 rural married women in India.” (Unpublished).

Silverman, J. G., M. R. Decker, N. Saggurti et al. 2008. "Intimate partner violence and HIV infection among married Indian women," Journal of the American Medical Association, 300(6):703-710.

Singh, A., B. Mahapatra and S. Dutta. 2008. "Spousal abuse and infant and child mortality in India," Asia-Pacific Population Journal, 23(2):33-54.

Singh, P., R. Rohtagi, S. Soren, M. Shukla et al. 2008. "The prevalence of domestic violence in antenatal attendees in a Delhi hospital," Journal of Obstetrics and Gynaecology, 28(3):272-275. 
Srinivasan, T. N and T. R. Suresh. 1990. "The nonspecific symptom screening method detection of nonpsychotic morbidity based on nonspecific symptoms," General Hospital Psychiatry, 12:106-114.

Stephenson, R., M. A. Koenig and S. Ahmed. 2006a. "Domestic violence and contraceptive adoption in Uttar Pradesh, India," Studies in Family Planning, 37(2):75-86.

Stephenson, R., M. A. Koenig and S. Ahmed. 2006b. "Domestic violence and symptoms of gynaecological morbidity among women in north India," International Family Planning Perspectives, 32(4):201-208.

Stephenson, R., M.A. Koenig, R. Acharya et al. 2008. "Domestic violence, contraceptive use, and unwanted pregnancy in rural India," Studies in Family Planning, 39(3):177-186.

Stephenson, R., A. Jadhav and M. Hindin, 2010. "Domestic violence and abortion among women health in rural India," (Unpublished).

Stevens, L. 2001. A Practical Approach to Gender-Based Violence: A Programme Guide for Health Care Providers and Managers. New York: UNFPA.

Subramanian, S. V., L. K. Ackerson, M. A. Subramanyam et al. 2007. "Domestic violence is associated with adult and childhood asthma prevalence in India," International Journal of Epidemiology, 36(3):569-579.

Sudha, S., S. Morrison and L. Zhu. 2007. "Violence against women, symptom reporting, and treatment for reproductive tract infections in Kerala state, southern India," Health Care Women International, 28:268-284.

United Nations Population Fund (UNFPA). 2010. "Addressing violence against women and girls in sexual and reproductive health services: A review of knowledge assets." New York, UNFPA.

Varma, D., P. S. Chandra, T. Thomas et al. 2007. "Intimate partner violence and sexual coercion among pregnant women in India: Relationship with depression and post-traumatic stress disorder," Journal of Affective Disorders, 102(1):227-235.

Verma, R. K and M. Collumbien. 2003. "Wife beating and the link with poor sexual health and risk behavior among men in urban slums in India," Journal of Comparative Family Studies, 34:61-74.

Visaria, L. 2002. "Many a slip between slap and lip: Women and their husbands respond to domestic violence," The Little Magazine, 111(4):40-43.

Visaria, L. 2000. "Violence against women: A field study," Economic and Political Weekly, 35(20):1742-1751.

Weiss, H. A., V. Patel, B. West et al. 2008. "Spousal sexual violence and poverty are risk factors for sexually transmitted infections in women: A longitudinal study of women in Goa, India," Sexually Transmitted Infection, 84(2):133-139.

World Health Organisation (WHO). 1997. Violence against Women. FRH/WHD/96.27. Geneva: WHO.

Zhu, Y and K. Dalal. 2010. "Childhood exposure to domestic violence and attitude towards wife beating in adult life: A study of men in India,” Journal of Biosocial Science, 42(2):255-69. 



\section{(P) Population Council}

South \& East Asia-Regional Office

Zone 5-A, Ground Floor

India Habitat Centre

Lodi Road

New Delhi 110 003, India 